Assessment of Effectiveness of

Geologic Isolation Systems

\title{
Perspectives on the Geological and Hydrological Aspects of Long-Term Release Scenario Analyses
}
J. A. Stottlemyre
R. W. Wallace
G. L. Benson
J. T. Zellmer

June 1980

Prepared for the

Office of Nuclear Waste Isolation

under its Contract with

U.S. Department of Energy

Pacific Northwest Laboratory

Operated for the U.S. Department of Energy by Battelle Memorial Institute 


\title{
NOTICE
}

This report was prepared as an account of work sponsored by the United States Government. Neither the United States nor the Department of Energy, nor any of their employees, nor any of their contractors, subcontractors, or their employees, makes any warranty, express or implied, or assumes any legal liability or responsibility for the accuracy, completeness or usefulness of any information, apparatus, product or process disclosed, or represents that its use would not infringe privately owned rights.

The views, opinions and conclusions contained in this report are those of the contractor and do not necessarily represent those of the United States Government or the United States Department of Energy.

\author{
PACIFIC NORTHWEST LABORATORY \\ operated by \\ BATTELLE \\ for the \\ UNITED STATES DEPARTMENT OF ENERGY \\ Under Contract DE-AC06-76RLO 1830
}

\author{
Printed in the United States of America \\ Available from \\ National Technical Information Service \\ United States Department of Commerce \\ 5285 Port Royal Road \\ Springfield, Virginia 22151
}

Price: Printed Copy \$.

$\because$ Microfiche $\$ 3.00$

NTIS
-Pages Selling Price

$\begin{array}{ll}001-025 & \$ 4.00 \\ 026-050 & \$ 4.50 \\ 051-075 & \$ 5.25 \\ 076-100 & \$ 6.00 \\ 101-125 & \$ 6.50 \\ 126-150 & \$ 7.25 \\ 151-175 & \$ 8.00 \\ 176-200 & \$ 9.00 \\ 201-225 & \$ 9.25 \\ 226-250 & \$ 9.50 \\ 251-275 & \$ 10.75 \\ 276-300 & \$ 11.00\end{array}$


Assessment of Effectiveness of

Geologic Isolation Systems

PERSPECTIVES ON THE GEOLOGICAL

AND HYDROLOGICAL ASPECTS OF LONG-TERM

RELEASE SCENARIO ANALYSES

J. A. Stottlemyre

R. W. Wall ace

G. L. Benson

J. T. Zellmer

June 1980

Prepared for the

Office of Nuclear Waste Isolation under its Contract with

U.S. Department of Energy

Pacific Northwest Laboratory

Richland, Washington 99352 


\section{ACKNOWLEDGMENT}

This research was supported by the Waste Isolation Safety Assessment Program (WISAP) conducted by Pacific Northwest Laboratory. The program was sponsored by the Office of Nuclear Waste Isolation, managed by Battelle Memorial Institute for the Department of Energy under Contract DE-AC06-76RLO 1830. On 1 October 1979, WISAP became the Assessment of Effectiveness of Geologic Isolation Systems (AEGIS) Program and the Waste/Rock Interactions Technology (WRIT) Program. This report was issued by AEGIS. 


\section{SUMMARY}

This report contains information that may be relevant to individuals involved with analyzing long-term release scenarios of specific repositories for nuclear waste. The bulk of the information is derived from recent studies in West Germany and the United States. Emphasis is on the specific geological and hydrological phenomena that, alone or in concert, could potentially perturb the area around specific repository sites.

Research is continuing on most of the topics discussed within this report. Because research is ongoing, statements and conclusions described in this document are subject to change.

The main topics of this report are: 1) fracturing, 2) geohydrology, 3) magmatic activity, and 4) geomorphology. Therefore, the site-specific nature of the problem cannot be overemphasized. As an example of how one might combine the many synergistic and time-dependent parameters into a concise format the reader is referred to A Conceptual Simulation Model for Release Scenario Analysis of a Hypothetical Site in Columbia Plateau Basalts, PNL-2892. For additional details on the topics in this report, the reader is referred to the Pacific Northwest Laboratory (PNL) consultant report listed in the bibliography.

The following comments are extracted directly from the end of each chapter of th is report.

\section{Fracturing}

- The types of fractures considered include: hydraulic fractures due to changes in interstitial fluid pressures, surficial fissures due to material loading or unloading, and faulting due to compressional or extensional stresses. This includes rupture on undetected faults, known "healed" faults, and virgin intact rock.

- The type of faulting, normal, reverse, thrust, or strike-slip, depends on the state of effective stress in the area. 
- Sea-floor spreading and plate tectonics help explain faulting in the vicinity of plate boundaries. Intraplate seismicity, however, is not well understood. Fortunately, it is infrequent.

- The primary release scenario involves creation of a hydraulic pathway, creation of significant groundwater flows, and continual replacement of the fluid in the source aquifer.

- If a hydraulic pathway is developed, the following information is necessary to quantify the consequences: 1) the time of the breach relative to waste emplacement; 2) the pathlength to the biosphere and the hydraulic conductivities along the path, 3) the fluid potentials, and 4) the sorption characteristics along the path.

- Thermally-induced advective flow, hydrothermal alterations, thermalstress cracking, salt-density gradients, and other physical and chemical interactions should be considered.

- Fault zones may be barriers to, as well as conduits for, the flow of water. Because of this, inundation of the waste could happen without significant flow through the repository.

- Estimates for faulting in an area should be based on the state of effective stress, material properties, recorded seismicity, observable cumulative deformation in the region, average strain rates, and anticipated changes in regional strain rates.

- Surficial fissures can extend for $100 \mathrm{~m}$ or more into the ground and can accept significant amounts of water for a 2 to 10-yr period.

- Radial and tangential fracturing near the margin of large ice sheets due to continental ice loading may be possible.

- Potential consequences associated with fractures include: 1) creation of a hydraulic pathway and perturbations of fluid potentials, 2) creation of a barrier to lateral groundwater fluid and subsequent changes in the water table, and 3) vibrational ground motions, which may be insignificant if the backfill material is properly engineered. 
Geohydrology

- Hydrologic factors desirable for a waste repository include: 1) low permeability, 2) high effective porosity, 3) low fluid potentials, 4) long flowpaths, and 5) high nuclide-retardation or sorption characteristics.

- These characteristics are subject to change at a given site, especially within a $10^{6}$-yr time frame. Some estimate of the rate of change of these characteristics, the probability, and magnitude is necessary.

- For a zone with a $10 \%$ porosity and a hydraulic gradient of 0.01 , a permeability of approximately $3 \times 10^{-4}$ darcy is needed to limit water migration to less than $1 \mathrm{~km}$ in $10^{5} \mathrm{yr}$. (Permeability of $3 \times$ $10^{-5}$ darcy may be necessary for $10^{6} \mathrm{yr}$ ).

- Fluid potentials can be affected by crustal faulting, surficial fissuring, hydraulic fracturing, climatic variations, denudation, stream erosion, sea-level changes, glaciation, irrigation, and fluid-waste disposal.

- Accurate prediction of how the hydrologic characteristics at a given site will change over the next $10^{5}$ to $10^{6} \mathrm{yr}$ is not currently possible or defendable. However, it may be possible to identify the various ways that a hydrogeologic system could be altered and to bound magnitudes and rates in a probabilistic manner. Having done this, one would have a set of possible future configurations of the geology and hydrology. The priority in analyzing those states would depend on relative occurrence probabilities and anticipated consequences.

- Brittle fracture of granitic or basaltic rocks does not necessarily dictate significant groundwater flows along the path. The source of water may be quickly depleted; therefore, an aquifer or surface water must be intersected if flow is to be maintained. 
- In addition to a continuous water source and creation of a fracture flow path, a potential sink such as a mine, a tunnel, or a second aquifer at a different dynamic head is necessary for a significant flow system to exist. If the source is also the sink, then the fluid column may be essentially static, subjected to thermally induced advection, or influenced by density and concentration gradients.

- Fracture systems need not remain open indefinitely. Creep closure in salt and mineral redeposition in hardrocks may heal the fractures. Similarly, under the lithostatic pressures at depth, fracture gouge or asperities are necessary to keep hardrock fractures open.

- For repositories in salt, fracturing of the caprock or bottom rock and slow dissolution of the salt is the most realistic scenario leading to groundwater transport of wastes. Solution collapse is also a possibility.

- Natural dissolution rates for salt of from 0.002 to $2.0 \mathrm{~mm} / \mathrm{yr}$ are reported in the literature.

- Fluid potentials might be affected by: 1) pressurized recharge, 2) a relative change in the location and/or elevation of recharge or discharge areas, 3) inundation by a body of surface water, 4) offset faulting, 5) the removal of low-permeability barriers, and 6) the creation of new fracture flowpaths.

- A 100-m drop in ocean level might increase the fluid potentials in shallow Gulf Coast aquifers by $30 \%$.

- An ocean-level increase of $100 \mathrm{~m}$ might inundate some coastal salt domes, reducing hydraulic gradients in aquifers to values of approximately 0.005 or lower.

- A significant increase in precipitation (300\%) could result in a twofold increase in hydraulic heads in shallow $(\leq 60 \mathrm{~m})$ aquifers. Deeper Gulf Coast aquifers should not be significantly affected. 
- The lowering of discharge points by erosion (an estimate of $15 \mathrm{~m}$ is used for the Gulf Coast) might increase fluid potentials in shallow Gulf Coast aquifers by as much as $40 \%$ to $60 \%$. Deeper aquifers should not be affected by more than $10 \%$.

- Offset faulting of 1 to $10 \mathrm{~m}$ in the Gulf Coast area could create barriers to lateral groundwater flow, especially if permeable sands are offset against relatively impermeable shales.

- Increased rainfall in southeastern New Mexico might increase the gradients in the Culebra aquifer from 0.005 to 0.007 if surface topography were to remain constant with time.

- At the Nevada Test Site (NTS), a two-fold increase in hydraulic head in the carbonate aquifers is possible as a results of a major increase in precipitation.

- Increased rainfall and groundwater recharge do not follow a one-toone correspondence. Much of the excess water is manifested as impounded surface water or as river runoff.

- Continental glaciation and lake impoundment in the vicinity of the Pasco Basin could increase subsurface recharge in the regional aquifers. However, increased flow in the interbeds and other aquifers does not necessarily indicate flux through any given basalt layer. Creation of a fracture flow path may still be necessary.

- Estimating how geohydraulic parameters might change from their current status at a given site is an important element in the assessment of long-term safety.

Magmatic Activity

- Only $3 \%$ of the currently active volcanoes are in midcontinental areas; the majority of these are associated with the East African Rift.

- Magmatic activity at a reasonable depth below the repository is assumed to be nonexistent at the time of waste emplacement, since features associated with it would be detectable. 
- Intrusive as well as extrusive activity must be considered. The consequences may be different, but it is assumed that the probability of occurrence is basically the same.

- Extrusive activity can be nonexplosive (flood basalts) or explosive (silicic volcanoes). Dispersal can be via lava flows, mud flows, pyroclastic flows, and air-fall.

- Igneous activity can result in: broad domal uplift and the development of radial and concentric fractures, faulting, accelerated erosion rates, the development of a hydrothermal convection system, and geyser activity.

- Volcanic activity within a 50-km radius of the repository but not directly intersecting the wastes might result in: surficial loading, drainage and erosional changes, climatic changes, and diagenesis with potential changes in the permeability of sedimentary layers.

- Past studies have resulted in probability numbers for magmatic activity ranging from 0.0 in the first $10^{4} \mathrm{yr}$ to $10^{-7}$ in $10^{6} \mathrm{yr}$.

- The PNL study is emphasizing emplacement rates and dispersal mechanisms, since the probability numbers appear to be sufficiently small for most sites that additional, order-of-magnitude refinement is not warranted.

Geomorphology

- This section briefly discusses: 1) slope failure, 2) denudation, 3) stream erosion, 4) glacial erosion, 5) coastal erosion, and 6) sedimentation.

- Slope failure is most likely to occur on a steep slope and can be enhanced by increased water saturation or head, jointing, low shearstrength, layer anisotropy, and favorable dip.

- Slope failure might cause a reduction of overburden thickness and/or surficial fissuring. 
- It appears that slope failure is not a particularly serious issue for an area with low relief and low tectonic activity. Furthermore, epeirogenic uplift, by itself, should not initiate slumping activity.

- Examples of denudation rates include: 1) $100 \mathrm{~m} / 10^{6} \mathrm{yr}$ for West Germany, 2) 50 to $75 \mathrm{~m} / 10^{6} \mathrm{yr}$ for the Pasco Basin, and 3) $160 \mathrm{~m} / 10^{6} \mathrm{yr}$ for the Grand Canyon area.

- The rate of denudation depends on climate, topography, material lithology, and human activity.

- Examples of stream erosion rates include: 1) $50 \mathrm{~m} / 10^{6} \mathrm{yr}$ for the Pasco Basin without anticlinal uplift, 2) $350 \mathrm{~m} / 10^{6} \mathrm{yr}$ for the Pasco Basin with anticlinal uplift, and 3) $800 \mathrm{~m} / 10^{6} \mathrm{yr}$ for the Grand Canyon.

- The potential consequences associated with denudation and stream erosion include: a reduction of overburden thickness, the removal of a relatively impermeable layer, and enhanced vertical groundwater recharge.

- It appears that uplifting an area has an order-of-magnitude greater impact on erosion rates than does changing the local climate.

- Glacial erosion involves ice scouring, local meltwater stream erosion, and massive flood erosion of the Missoula type.

- Ice erosion rates are temporally and spatially variable. The magnitudes of such erosion may vary from a few meters per $10^{6} \mathrm{yr}$ to hundreds of meters per $10^{6} \mathrm{yr}$.

- Future deep erosion by ice action will presumably occur only in those areas where deep erosion has already occurred.

- Based on present glacial activity, ice erosion is, on the average, four times more effective than fluvial erosion.

- The probability of massive flooding in the Pasco Basin during and immediately following a glacial episode is $10^{-4} / \mathrm{yr}$ and the consequences would include an impounded lake in the Pasco Basin and transient groundwater recharge. 
- The potential consequences associated with glaciation include:

1) removal of overburden and removal of a low permeability confining layer, 2) flooding and short-term impoundment of water in lowland areas, 3) fracturing near the margin of the ice sheet, and 4) deep groundwater recharge near the margin of the ice sheet.

- Sea level may vary by as much as $100 \mathrm{~m}$ over a $10^{5}$-yr period due to the glacial activity; and by $250 \mathrm{~m}$ over $10^{6} \mathrm{yr}$ due to tectonic activity.

- At present, the ocean is rising at 3 to $4 \mathrm{~mm} / \mathrm{yr}$. Potential future rates are 3 to $4 \mathrm{~mm} / \mathrm{yr}$ to $4 \mathrm{~cm} / \mathrm{yr}$.

- Coastal erosion and sedimentation are not considered significant to a deeply $(>600 \mathrm{~m})$ buried repository.

- Fluctuations of sea level can affect hydraulic gradients in nearcoastal aquifers. For example, a 100-m fall in ocean level might increase hydraulic gradients by $30 \%$ in the Gulf coast area. 


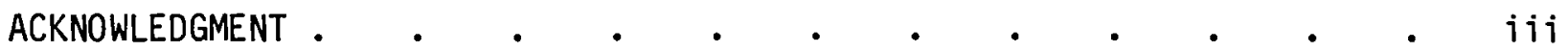

SUMMARY

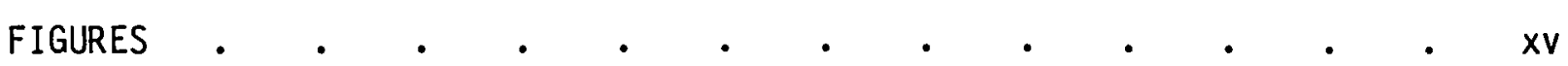

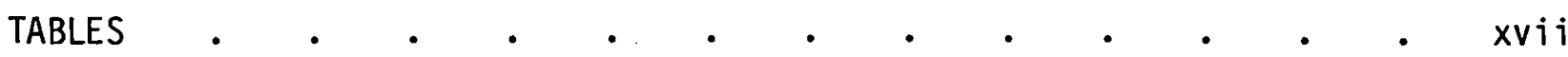

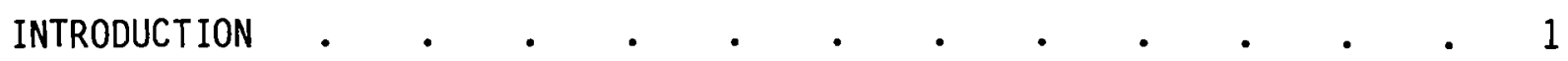



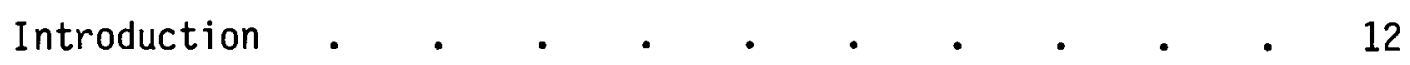

Plate Tectonics as Related to the Probability and Consequences

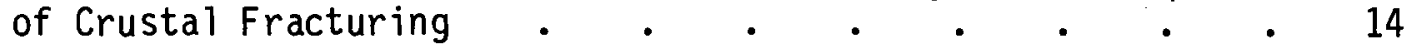

Potential Consequences Associated with Fracturing • • • 19

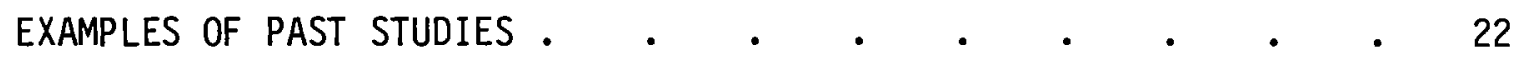

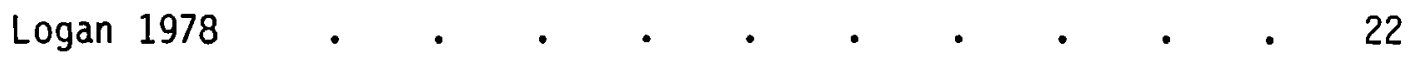

Claiborne and Gera 1974 . . . . . . . . 23

Bertozzi et a1. 1978. . . . . . . . . . . 24

Summary of Current Studies at Pacific Northwest
Laboratory.

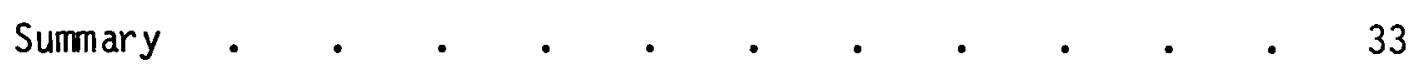

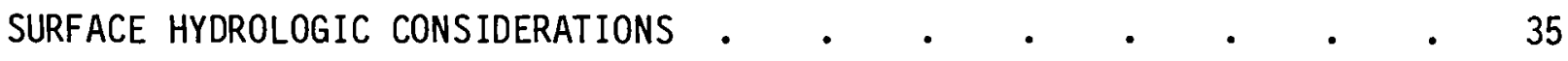

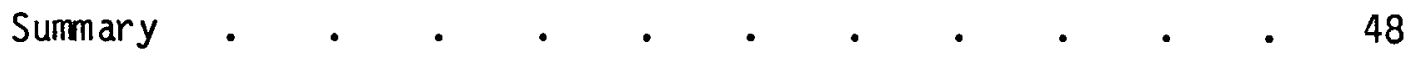

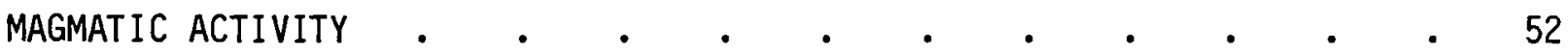

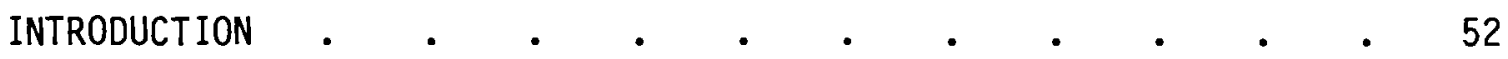

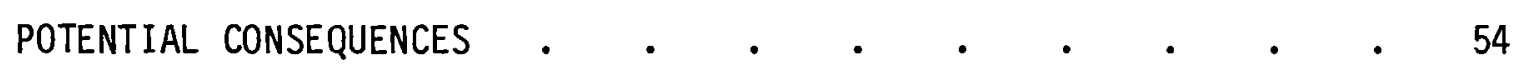

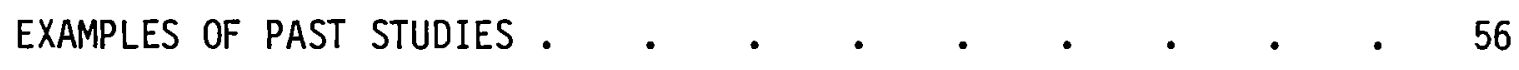

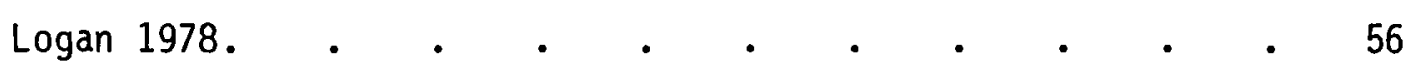

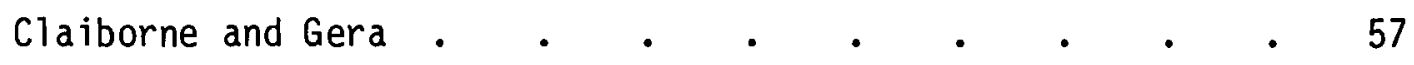






Current Study at Pacific Northwest Laboratory. $\quad$ • $\quad$. 59

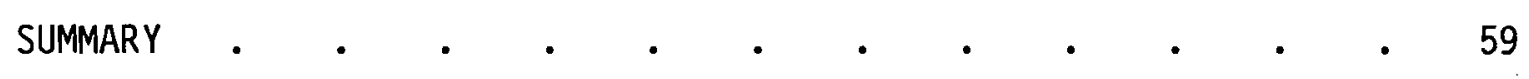

GEOMORPHOLOGY •

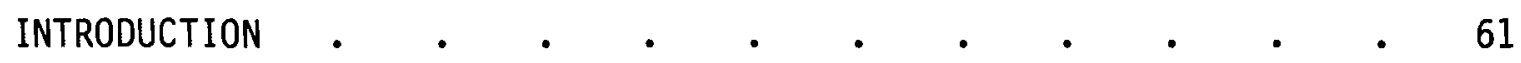

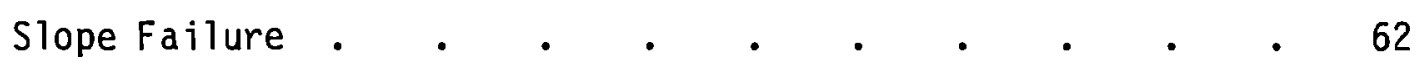

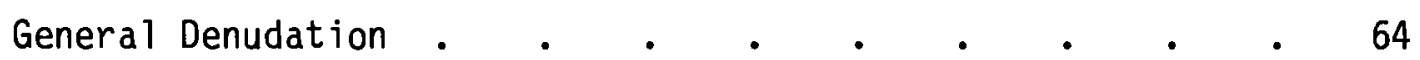

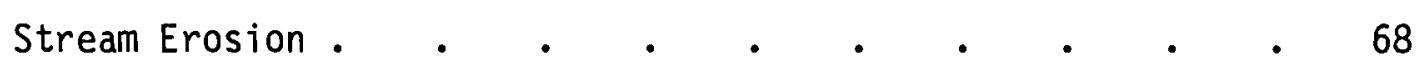

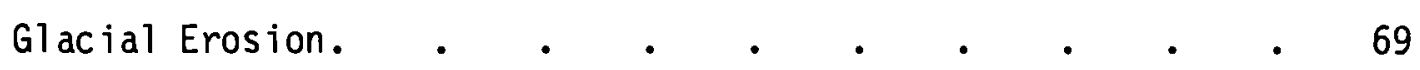



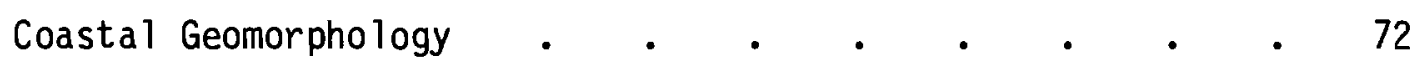

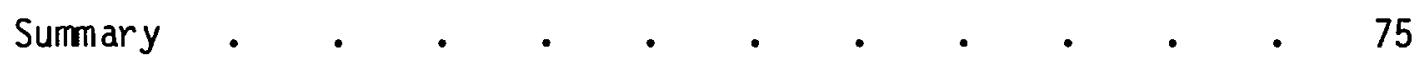

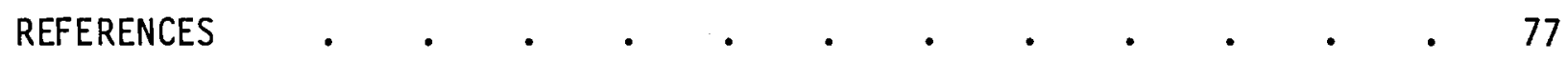

APPENDIX - GLOSSARY OF GEOHYDROLOGIC TERMS • • • • • • • • • $\quad$ - A.I 


\section{FIGURES}

1 Waste Isolation Safety Assessment Program . . . . . . 2

2 Surficial Processes Interactions .

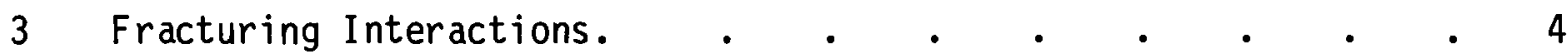

4 Meteorite Impact Effects . . . . . . . . . . 5



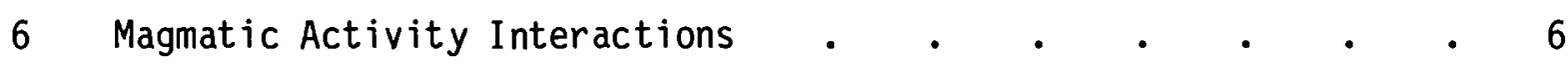

7a Initial System System State Time $=0 \mathrm{yr} . \quad$. . . . . . 7

7b System Perturbation Time $=10^{3} \mathrm{yr}$...$\quad$. . . 7

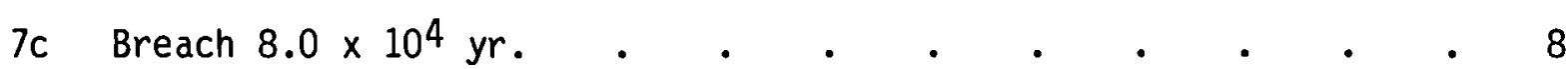

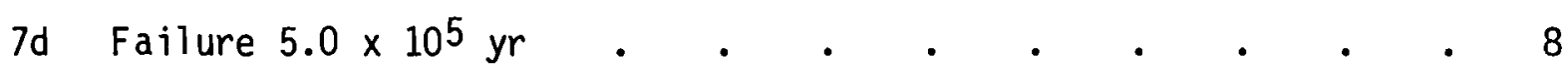

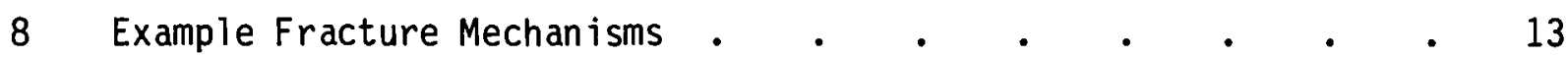

$9 \operatorname{Main}$ (I), Branch (II) and Secondary (III) Faulting . . . 14

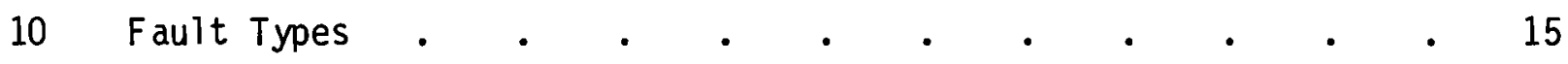

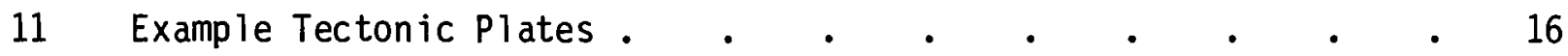

12 Global Seismicity and Earthquakes • • • • • • • 17

13 Seismic Risk Zones .

14 Example Layered Earth Model • • • . • • • . 20

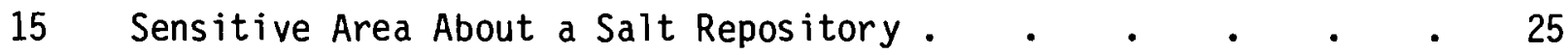

16 Typical Permeabilities of Basin and Range Province Rock. . $\quad 37$

17 Representative Permeabilities of Gulf Coast Materials • • • 38

18 Basin and Range Granitic Stock . . . . . . . . 40

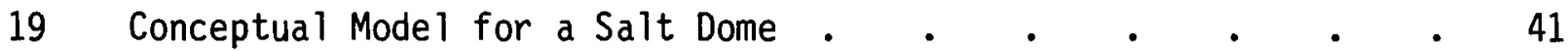

20 Conceptual Model of a Bedded Salt Formation . $\quad$ - . . . 42 
21 Conceptual Model of a Repository in Basalt . . . . . 43

22 Examples of Major Volcanoes . . . . . . . . . 53

23 Relation of Denudation Rates to Relief-Length Ratio and Drainage Basin Relief . . . . . . .

68 


\section{TABLES}

1 Potentially Disruptive Phenomena • • • . • • 10

2 Relative Strain Release Normalized in Terms of Magnitude for

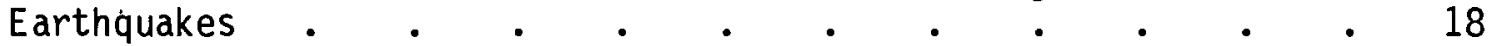

3 Faulting Frequency Over the Sensitive Area Surrounding a Hypothetical Repository in Germany. • . . . . . 26

4 Occurrence Probabilities for Faulting . • . . • . 26

5 Representative Values of Permeability for Natural Materials. . 36

6 Example Hydrologic Characteristics for an Area in the Columbia

Plateau Region. • . . . • • • • • . 47

7 Transport Distances for Several Types of Magmatic Eruptions. $\quad 55$

8 Probability of Volcanism. . . . . . • • • 58

9 Probability of Igneous Intrusion Fracturing Impermeable Layers . 58

10 Slumping or Large Scale Mass Wasting Probabilities . . 63

11 Probabilities of Massive Denudation . • • • . . 64

12 Past and Present Rates of Denudation . . . . . . 65

13 Rates of Regional Erosion in the United States . . . . 66

14 Relative Rates of Denudation in Uplands and Lowlands in Different Climates • • • • • • • • • • •

15 Present Rates of Glacial Erosion . . . . • . . 71

16 Changes in Sea Level . 



\section{INTRODUCTION}

The Waste Isolation Safety Assessment Program (WISAP) was established at Pacific Northwest Laboratory (PNL) to develop a methodology for the assessment of the post-closure safety of nuclear waste repositories in geologic media. The program was sponsored by the Office of Nuclear Waste Isolation (ONWI) under its contract with the Department of Energy (DOE) as part of the National Waste Terminal Storage Program (NWTS).

There are two basic steps in assessing repository post-closure safety:

1. to define and analyze breach scenarios and the pattern of events and processes that would cause each breach,

2. to identify and analyze the consequences of radionuclide transport and interactions that may occur subsequent to a repository breach.

The organization of WISAP is illustrated in Figure 1. The release scenario analys is unit, Task 1 defined and analyzed the breach scenarios. The output of Task 1 is used to define the initial conditions describing the state of the geosystem at the time of breach.

Figures 2 through 7 illustrate how various phenomena can combine to: 1) perturb the geologic and hydrologic system surrounding the repository, 2) breach the repository thus initiating transport of the contaminants within the geosphere, and 3) cause repository failure by injecting the contaminants into the biosphere system. The release scenario task terminates upon identifying and characterizing breaches. The release consequence task then studies the potential for release of contaminants to the biosphere. This study uses sophisticated hydrologic and nuclide-transport computer codes.

For the hydrogeologic scenarios, the following data must be transferred between the two tasks: 1 ) the time of the breach (contaminant release from the immediate repository boundaries), 2) the preferential pathway to the biosphere, 3 ) the effective porosities and conductivities along the path, 4) the length of each segment of the path, 5) hydraulic heads and potential gradients along the path, and 6) if possible, the state of effective stress, the temperature and 


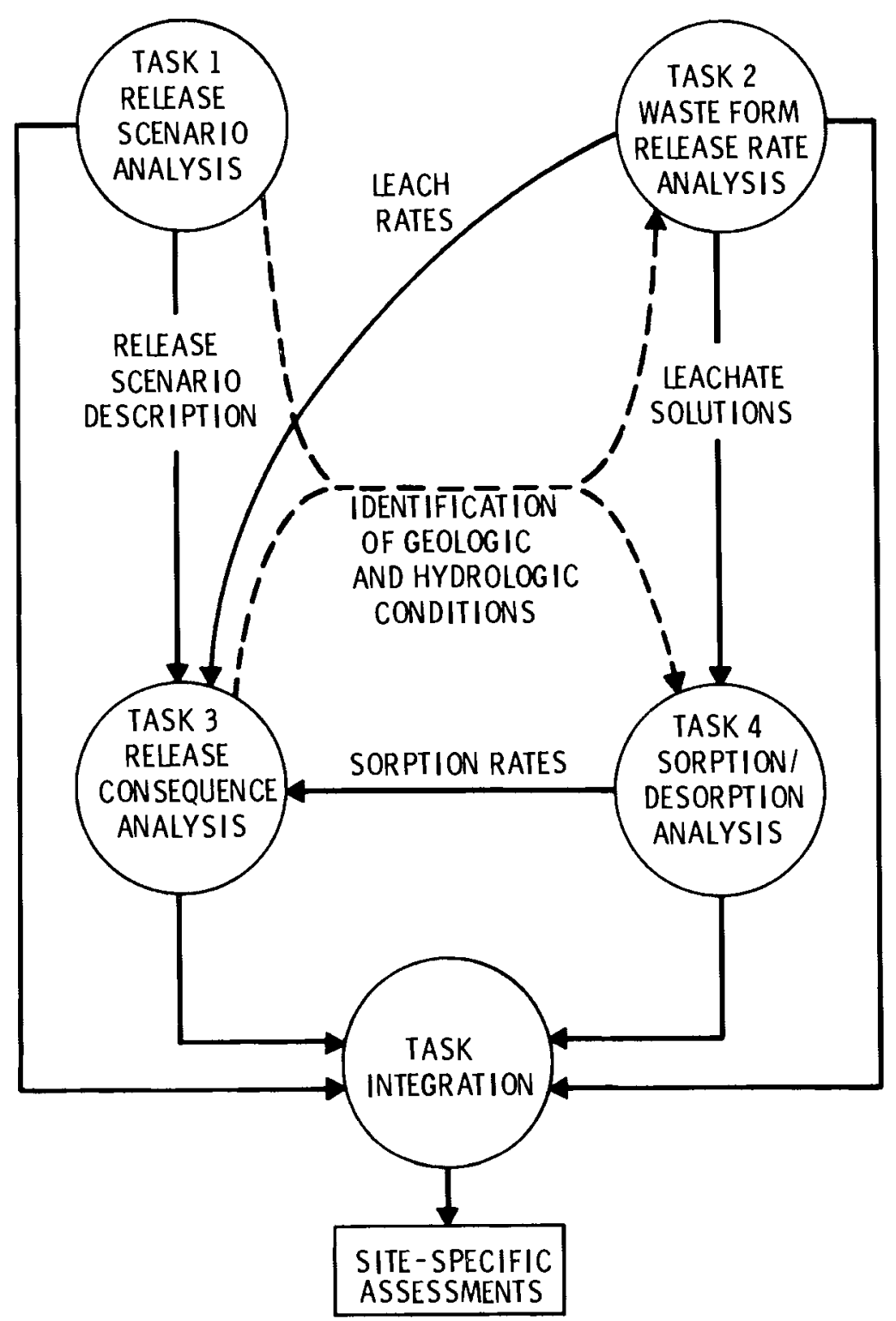

FIGURE 1. Waste Isolation Safety Assessment Program

the geochemical characteristics along the path. With this information, the release consequence task must estimate leach rates, water flow volumes and velocities, and the flux of contaminants.

The main mission of the release scenario task is, therefore, to quantify and bound how the geologic and hydrologic system surrounding the repository might change in the future and to determine if such change or perturbation 


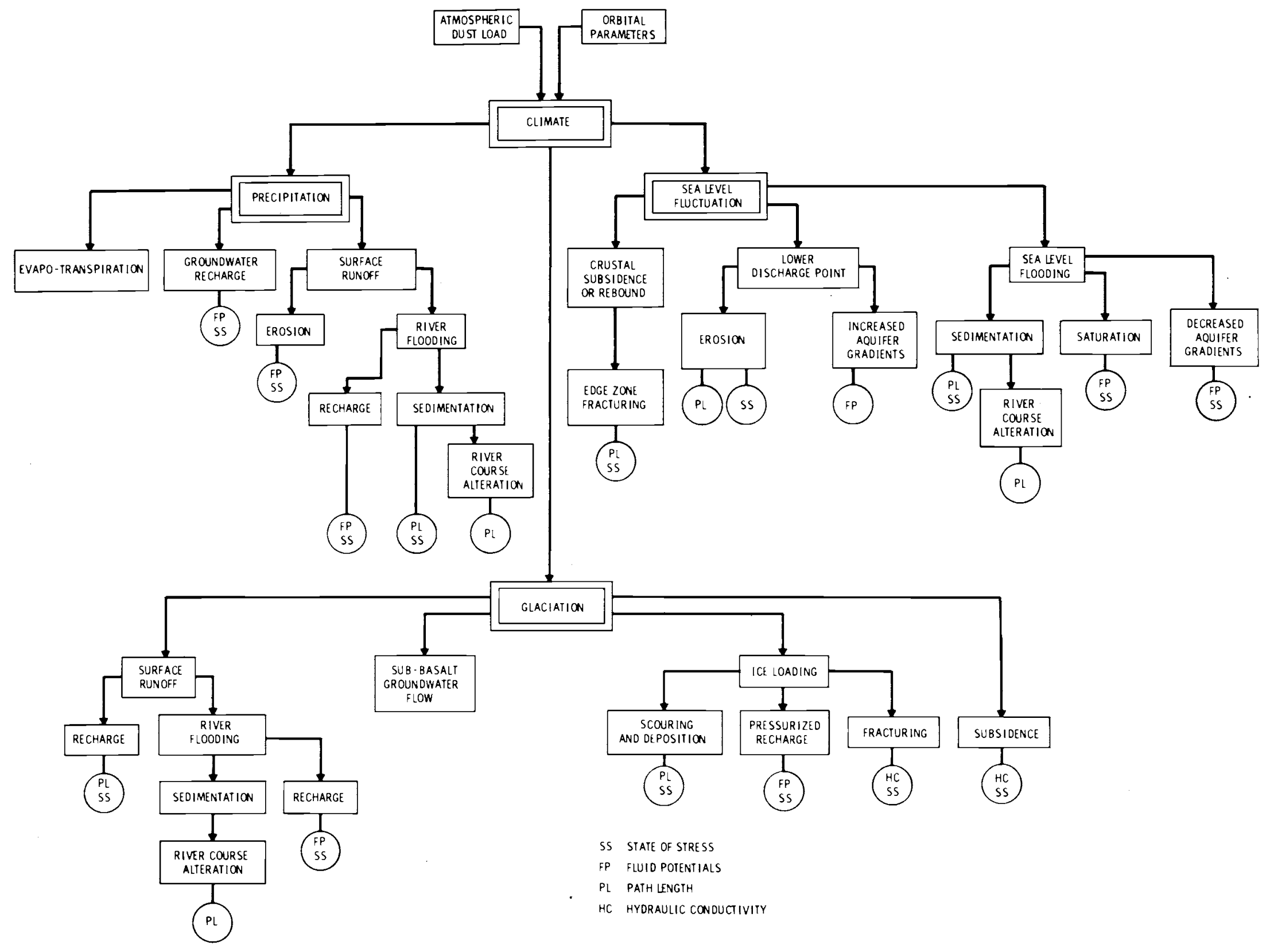

FIGURE 2. Surficial Processes Interactions 




FIGURE 3. Fracturing Interactions 




FIGURE 4. Meteorite Impact Effects

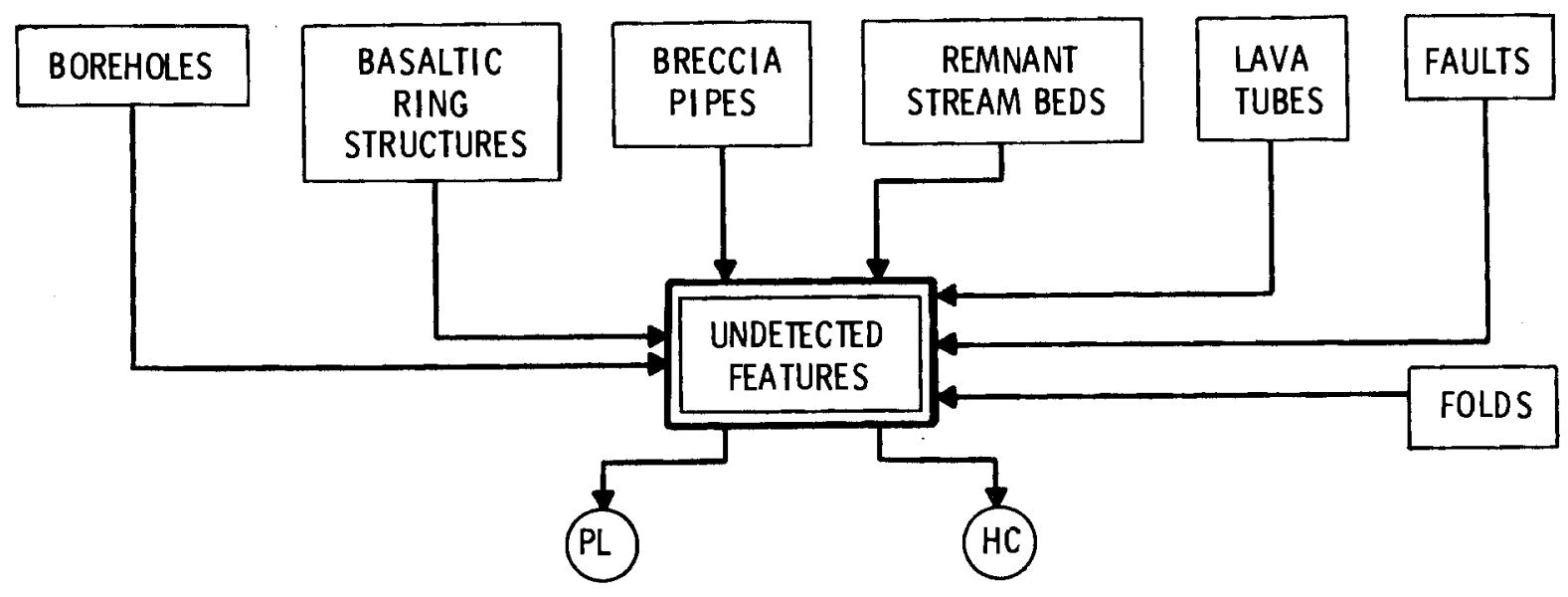

FIGURE 5. Interactions with Undetected Features

signifies a breach. The output is a "complete" set of potential future geologic and hydrologic system configurations and an estimate of the likelihood that the repository site will exist in any one of them. Obviously, a critical parameter is the maximum time that must be considered since the hydrogeologic characteristics describing each system state will diverge as a function of time. For the purpose of illustration, $10^{6} \mathrm{yr}$ has been arbitrarily selected for this report. Naturally, the uncertainty or error bands also increase with time and this fact must be integrated into any analysis. 


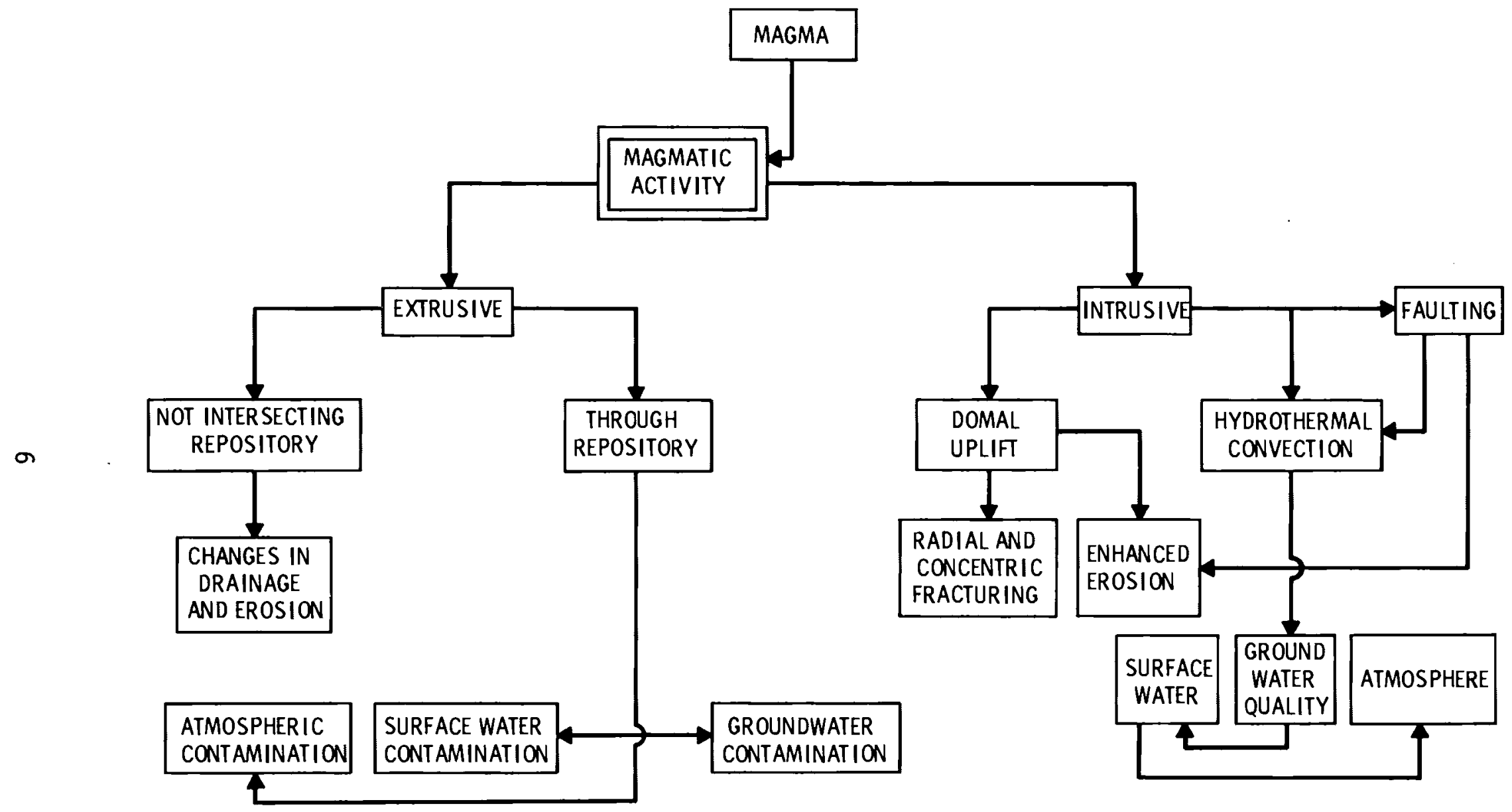

FIGURE 6. Magmatic Activity Interactions 




FIGURE 7a. Initial System State Time $=0 \mathrm{yr}$

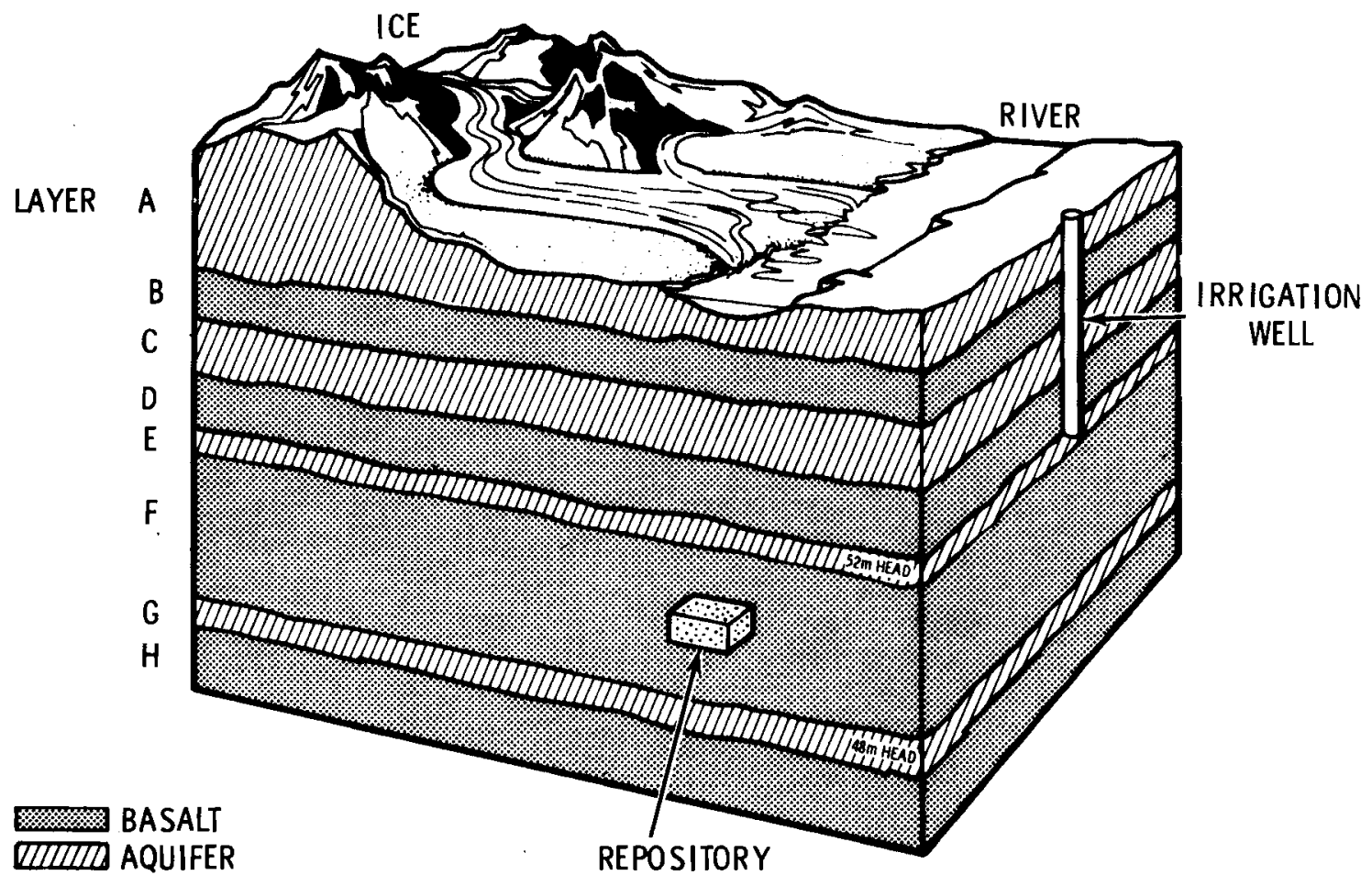

FIGURE 7b. System Perturbation Time $=10^{3} \mathrm{yr}$ 


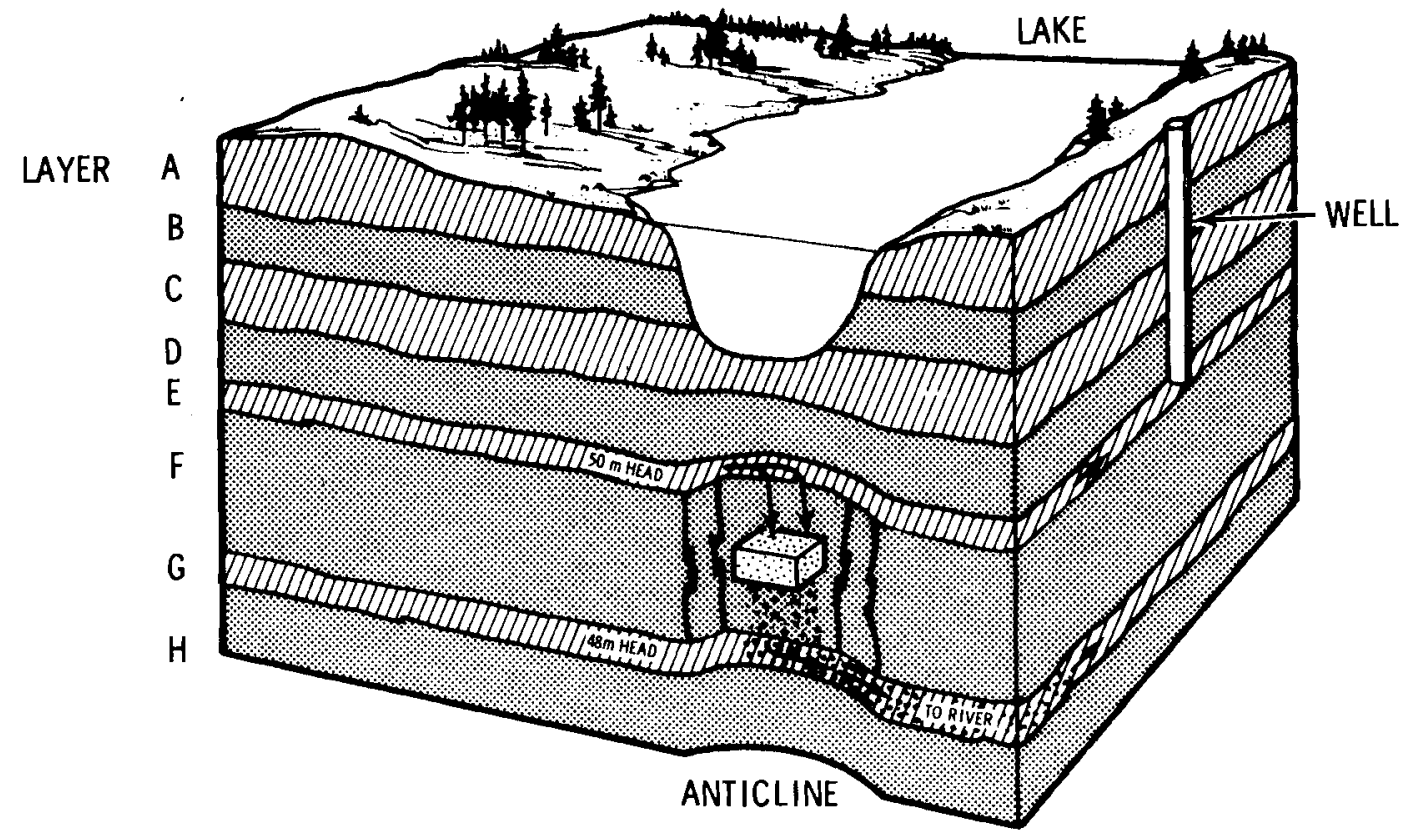

FIGURE 7c. Breach (Potential Failure) $8.0 \times 10^{4} \mathrm{yr}$

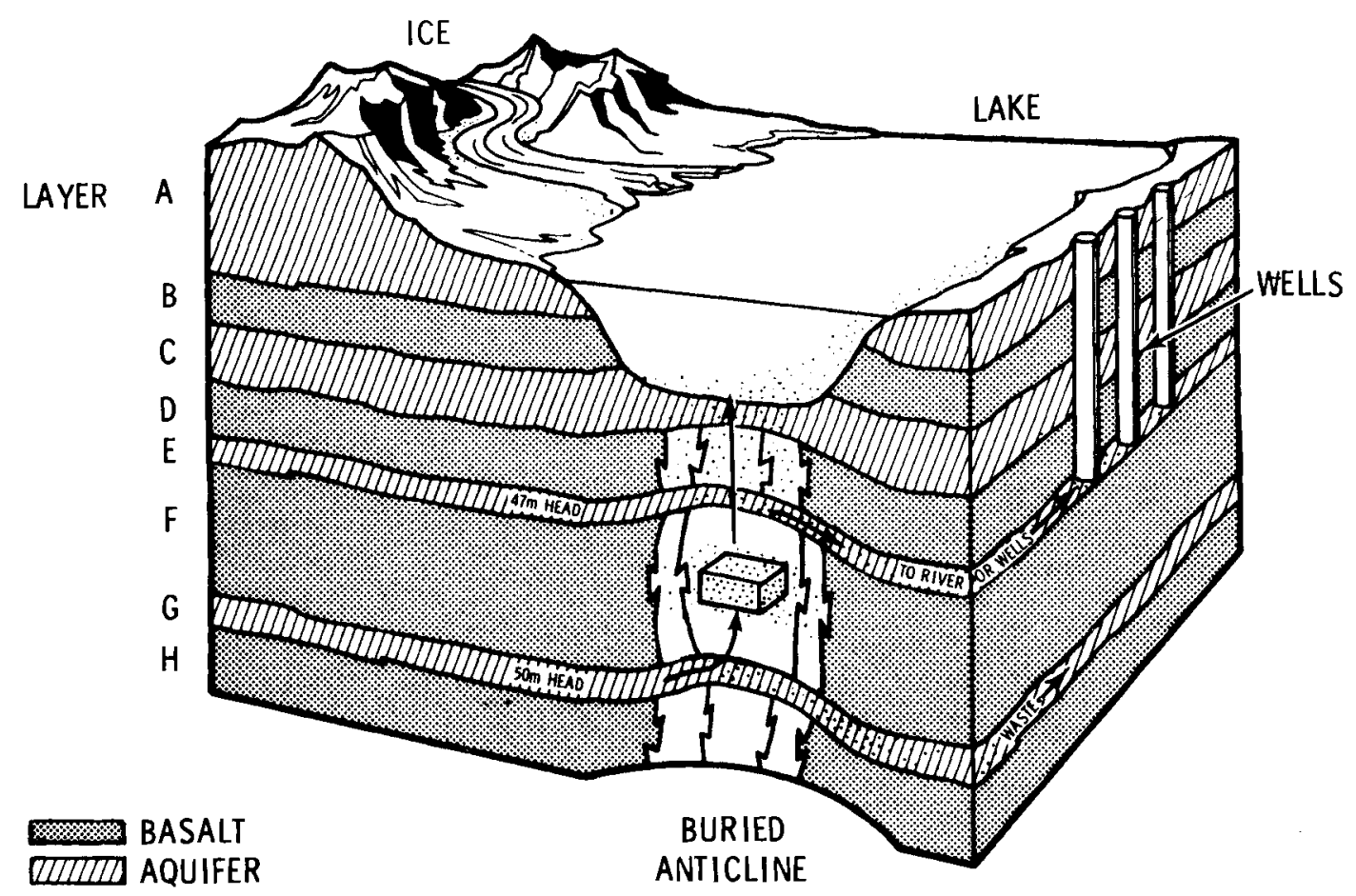

FIGURE 7d. Failure $5.0 \times 10^{5} \mathrm{yr}$ 
A computerized methodology entitled "Repository Simulation" is being proposed as a vehicle to conduct such studies on a site-specific basis. A conceptual model for a hypothetical site in the State of Washington is presented in a recent report, PNL-2892 (Stottlemyre, Petrie, Benson and Zellmer 1979).

A wide range of potentially disruptive phenomena must be considered in an analysis. These phenomena are generally synergistic and site and time dependent. Table 1 lists example "disruptive phenomena", and categorizes them as natural or man-induced. Near-field phenomena, such as mining-induced or thermal-induced stresses have been specifically excluded from this phase of the study. However, some comments concerning these near-field factors will be made when appropriate.

Release scenario analysis deals with two general classifications of phenomena. The first type has extremely high occurrence probabilities, but relatively unimportant consequences. Even though the phenomena may be continuously ongoing at the repository site, the changes or perturbations to the geologic system are such that the probability of direct release of nuclides from the geologic barrier is very small. Denudation, stream erosion and climatic variations are examples of this type of phenomena. The second classification includes phenomena with extremely low occurrence probabilities, but potentially significant consequences. Meteorites, magmatic activity, faulting through the repository, and in some cases, glaciation are examples of this type of phenomenon. Estimating occurrence probabilities is an extremely difficult task because of the lack of site-specific data. However, it may be possible to demonstrate that some probabilities are so small that further study and refinement is not warranted. The following discussion is presented as a guide to determining an appropriate probability threshold below which a phenomena should not be considered in future studies.

Assume that the probability of a single event or combination of events leading to nuclide release from the repository in any one year is $P_{0}$. The probability of this not to take place during any one year is:

$$
P_{1,0}=1-P_{0} \text {. }
$$


TABLE 1. Potentially Disruptive Phenomena

Natural

Climatic Fluctuations

Glaciation

Denudation and Stream Erosion

Magmatic Activity

- Extrusive

- Intrusive

Epeirogenic Displacement

- Igneous Emplacement

- Isostasy

Orogenic Diastrophism

- Near-Field Faulting

- Far-Field Faulting

- Diapirism

Static Fracturing

- Surficial Fissuring

- Impact Fracturing

- Hydraulic Fracturing

Meteorites

Dissolution

Sedimentation

Flooding

Undetected Features

- Faults

- Breccia Pipes

- Lava Tubes

- Gas or Brine Pockets

- Shear Zones
Man-Related

Improper Design/Operation:

- Shaft Seal Failure

- Improper Waste Emplacement

Undetected Past Intrusion:

- Undiscovered Boreholes or

- Mineshafts

Inadvertent Future Intrusion:

- Archeological Exhumation

- Weapons Testing

- Non-Nuclear Waste Disposal

- Resource Mining (Mineral, Hydrocarbon, Geothermal, Salt Water)

- Storage of Hydrocarbons or Compressed Air

Perturbation of Groundwater

System:

- Irrigation

- Reservoirs

- Intentional Artificial

Recharge

- Establishment of Population Center 
The probability $P_{n, 0}$ for this release not to take place in $n$ years is:

$$
P_{n, 0}=1\left(1-P_{0}\right)^{n} \text {. }
$$

P. E. Gretener, in his paper on the "Significance of the Rare Event in Geology," (Gretener 1967) shows that for small $P_{0}$, the estimate $P_{n, 1}$ can be adequately expressed by the well-known Poisson limit for the binomial distribution:

$$
P_{n, 1}=1-1-\frac{n}{1} p_{0}+\frac{n}{2} p_{0}^{2}-\frac{n}{3} p_{0}^{3}+\cdots
$$

This expression can be used in the following argument for bounding the range of release probabilities that should be studied. As a minimum bound, a yearly release probability of $P_{0}=10^{-3}$, classifies the event or combination of events as "rare." The age of the earth is used as a measure for the upperbound cutoff. "The age of the crust is estimated to be $3.5 \times 10^{7}$ to $5.5 \times 10^{9} \mathrm{yr}$ (Holmes 1964), so that an event or combination of events with a yearly release probability of $P_{0}=10^{-7}$ still has a $98 \%$ chance of occurring in a time period equal to the age of the earth. An event with a $P_{0}=10^{-10}$ has only a $20 \%$ chance of occurring. When the event becomes so improbable that $P_{0}=10^{-11}$, it becomes virtually impossible even within a time period equal to the age of the earth" (Gretener 1967).

Thus, to be included in a safety assessment of a geologic repository, a release scenario should have a probability greater than $10^{-10}$ to $10^{-11} / \mathrm{yr}$. The excavation or fracturing of a repository site by meteorite impact is such an example. W. K. Hartman (1978) has determined that the probability of such an event is $10^{-11} / \mathrm{yr}$ to $10^{-13} / \mathrm{yr}$. Consequently, it may be possible to exclude meteorite impact from release scenario analysis.

Release scenarios provide a method of determining the events or sequences of events that may ultimately cause breaching of the repository. Consequently, the primary goal of the repository simulation model is to identify and estimate the probabilities of disruptive events that, alone or in concert, might compromise the isolation status of a nuclear waste repository and to describe the possible geological and hydrological system states present at the time of a breach. This information must include plausible release scenarios and set 
bounds on the parameters used in the transport models. Such information can then be used to describe initial conditions in the release-consequence transport models.

Geologic and hydrologic systems are highly complex and, in many respects, inadequately understood, especially the long-term effects of disruptive phenomena. Our methodology is designed to help assess these effects and the longterm safety of repositories for nuclear waste. The methodology is evolutionary and can be adaptive to incorporate advances in the geologic and hydrologic understanding and to accommodate modifications in repository licensing requirements. Additionally it provides a flexible framework for the discussion and development of repository licensing criteria related to natural disruptive phenomena.

The discussions in this report represent only the current evolutionary thought on the various disruptive phenomena. As work progresses in the NWTS program, the phenomena must be analyzed on a site-specific basis. This will allow a more narrow research scope and a refined analysis of the potential effects of the disruptive phenomena.

\section{FRACTURE SYSTEMS}

\section{Introduction}

The geologic media hosting a repository should have a permeability low enough to preclude significant quantities of flowing groundwater. Fracturing is one phenomenon that might alter the hydraulic conductivity of the host rock. A fracture sytem can be envisioned as a series of interconnected cracks which allow a permeability to exist different from that of the intact rock. Such a system might be characterized by: fracture density, continuity, isotropy, length, aperture width, and mineralogy.

The type of fractures being considered in this report include: 1) hydraulic fractures that are created when the interstitial or pore fluid pressures exceed the tensile strength of the rock mass, 2) surficial fractures that result from material loading or unloading, 3) faulting of the basement rock with or without rupture of the overlying rock, and 4) fractures associated with ice loading. Figure 8 illustrates these four fracture mechanisms. 




(a) HYDRAULIC FRACTURE

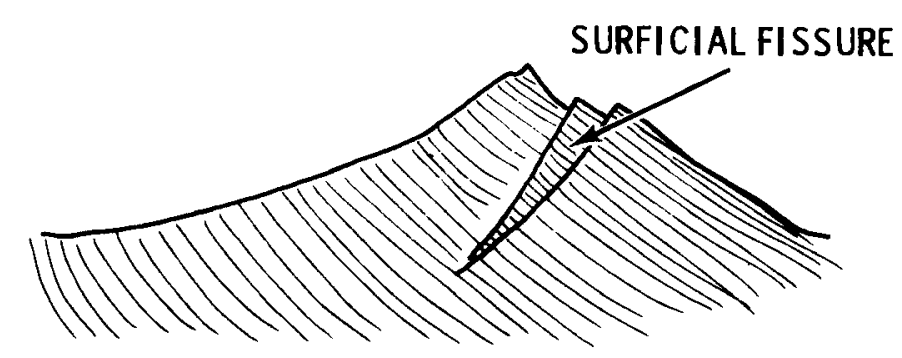

(b) SURFICIAL FISSURE

$\stackrel{\breve{\omega}}{ }$

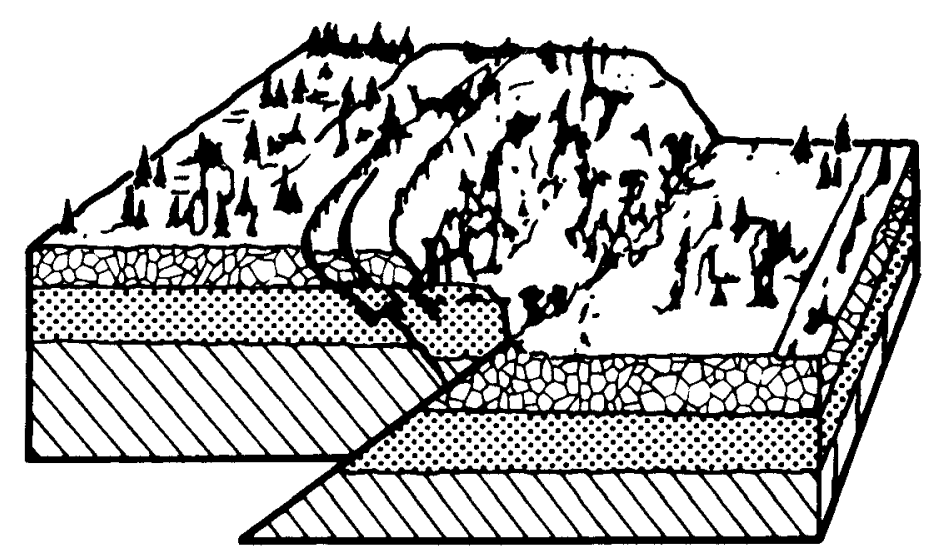

(c) CRUSTAL FAULTING

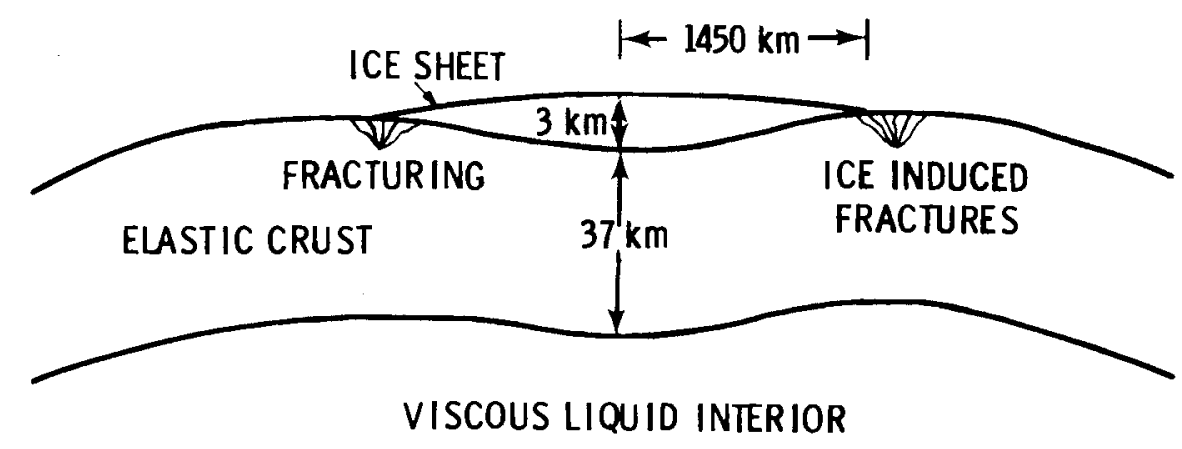

(d) ICE LOAD FRACTURING

FIGURE 8. Example Fracture Mechanisms 
Figure 9 shows three categories of faults: main fault systems, branch faults, and secondary faults. Rupture occurs in intact rock, along fractures considered healed and, most commonly, along active fault systems. There are a variety of fault geometries. Figure 10 presents the general classifications of normal, reverse, oblique, and strike-slip faults. Thrust and strike-slip faults are thought to be associated with tectonically active areas where lateral crustal stresses are of the compressional type. High angle reverse faults can also indicate crustal compression. Normal faulting, on the other hand, is generally confined to areas undergoing crustal lengthening or extension.

Faulting is controlled primarily by the state of effective stress existing on a regional or local scale. Stress components include tectonic forces, lithostatic or rock overburden pressures, and interstitial or pore fluid pressures. Since plate tectonics plays a significant role in defining this regional stress state, the following brief discussion is presented.



FIGURE 9. Main (I), Branch (II) and Secondary (III) Faulting (Slemmons 1977)

Plate Tectonics as Related to the Probability and Consequences of Crustal Fracturing

Since the advent of $\mathrm{plate-tectonic}$ and sea-floor-spreading theory, the geoscience community has advanced rapidly in its understanding of faulting and 


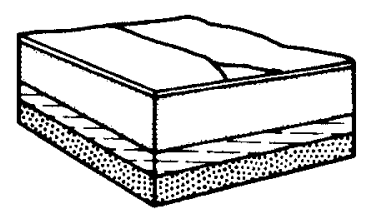

BLOCK BEFORE FAULTING


FIGURE 10. Fault Types

REVERSE FAULT
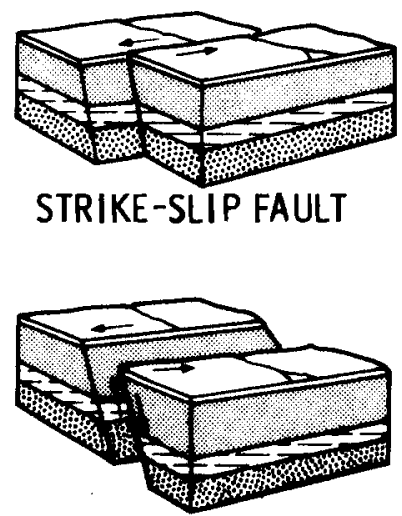

OBLIQUE-SLIP FAULT

seismicity. Knowledge gained on a global scale now allows earth scientists to divide the earth's crust and uppermost mantle into 10 to 14 individual crustal units or plates. These plates are in motion, with the leading edges being continually subducted into large descending troughs. The trailing edges are being continually created by the solidification of upward moving magma associated with extensive midoceanic ridges.

Figure 11 illustrates this process. These subduction zones, oceanic ridges, and plate-junction zones are belts of major earthquake and volcanic 


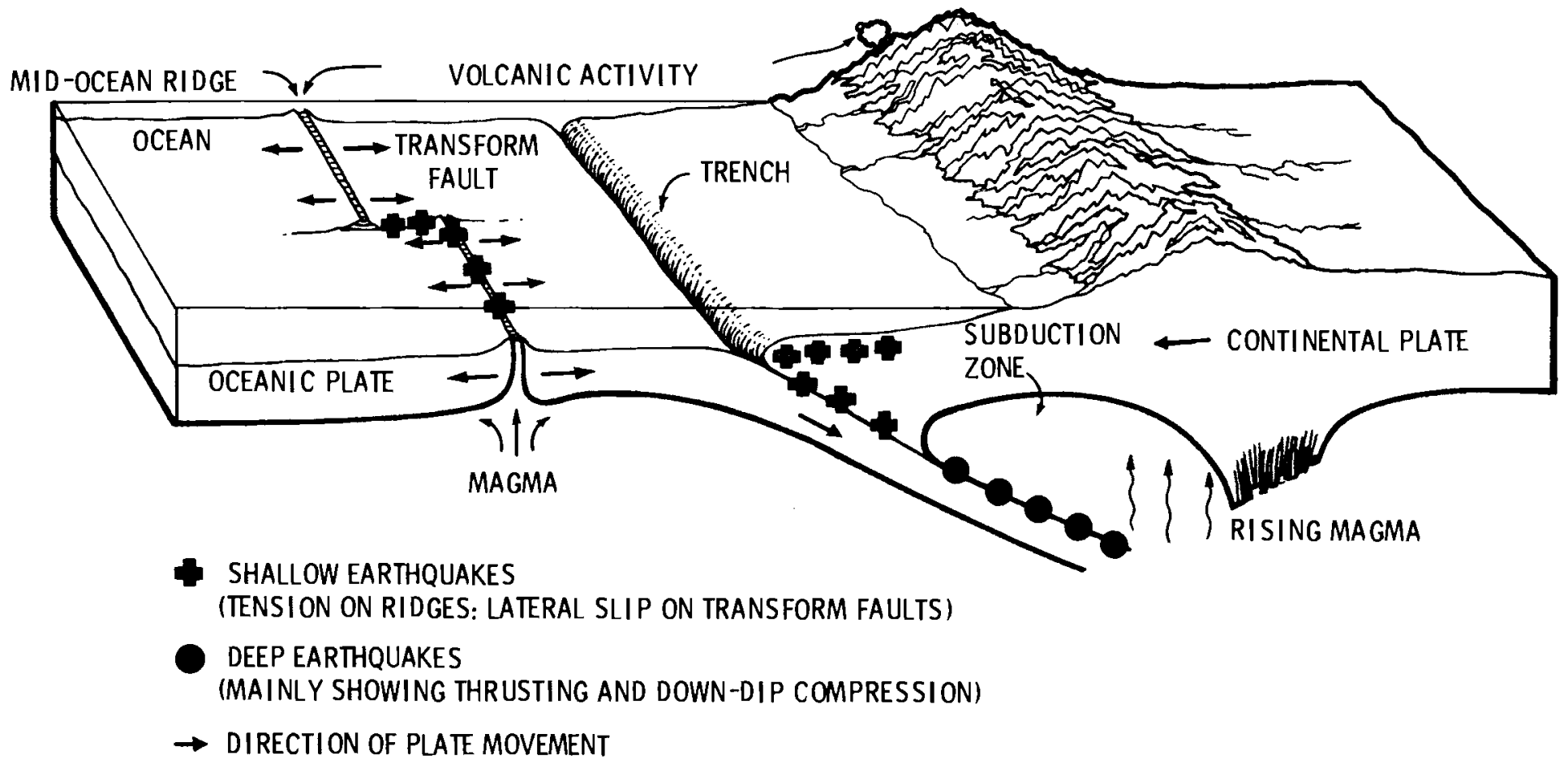

FIGURE 11. Example Tectonic Plates 
activity as shown in Figure 12. For example, the junction between the Pacific and the North American plates forms, in part, the San Andreas fault system and related systems along the west coast of the United States.

For any repository sited west of Nevada or the Idaho batholith, an understanding of plate junctions and relative motions is important to addressing future faulting or volcanism. However, intraplate or midcontinental activity is not without precedent. Examples include the major damaging earthquakes at New Madrid, MO (1811-1812) and Charleston, SC (1886). Intraplate seismicity has also been observed in oceanic plates, although the mechanism for its origin is not well understood.

No part of the U.S. can be considered devoid of faulting and earthquakes; however, it is possible to characterize zones in terms of relative seismic risk. One technique is to use the relative strain release throughout the U.S. as an index of current tectonic activity (Algermissen 1969). Strain release



FIGURE 12. Global Seismicity and Earthquakes 
is proportional to the square root of the energy released, the energy released being determined from the magnitude of the earthquake. Each increase in Richter magnitude represents a ten-fold increase in energy release. Algermissen has divided the conterminous United States into four areas on the basis of data compiled from earthquakes between 1900 and 1965. The areas and equivalent magnitude for earthquakes during this period are listed in Table 2.

This reveals that from the standpoint of strain release, the Pacific West is the most active and the Central Plains, the least. Earthquake recurrence plots substantiate this conclusion. Obviously, any probability numbers reflecting the potential for faulting in the vicinity of a repository must be tailored to the specific site. Figure 13 presents a seismic risk map as given by Algermissen (1969).

With respect to intraplate activity, the East African Rift Valley represents the initial phase of fracturing of an intact plate. Subsequent spreading of this rift may ultimately lead to invasion by the ocean. This system extends for thousands of miles, supports extensive magmatic activity, and is prone to seismic activity. However, the rates associated with such midcontinental rifting are sufficiently slow to preclude, or at least minimize consideration of intraplate rifting in any safety assessment studies.

TABLE 2. Relative Strain Release Normalized in Terms of Magnitude for Earthquakes (Algermissen 1969)

No. of Equiv. Mag 4

Earthquakes $/ 1000 \mathrm{~km}^{2}$

Area

(1900-1966)

Pacific West

(west of 1ong. 114 W)

12.0

Rocky Mountains

2.0

(1 ong $106-114 \mathrm{~W}$ )

Central Plains

(long 92 -106 W)

0.14

Eastern U.S.

(east of long $92 \mathrm{~W}$ )

0.74 


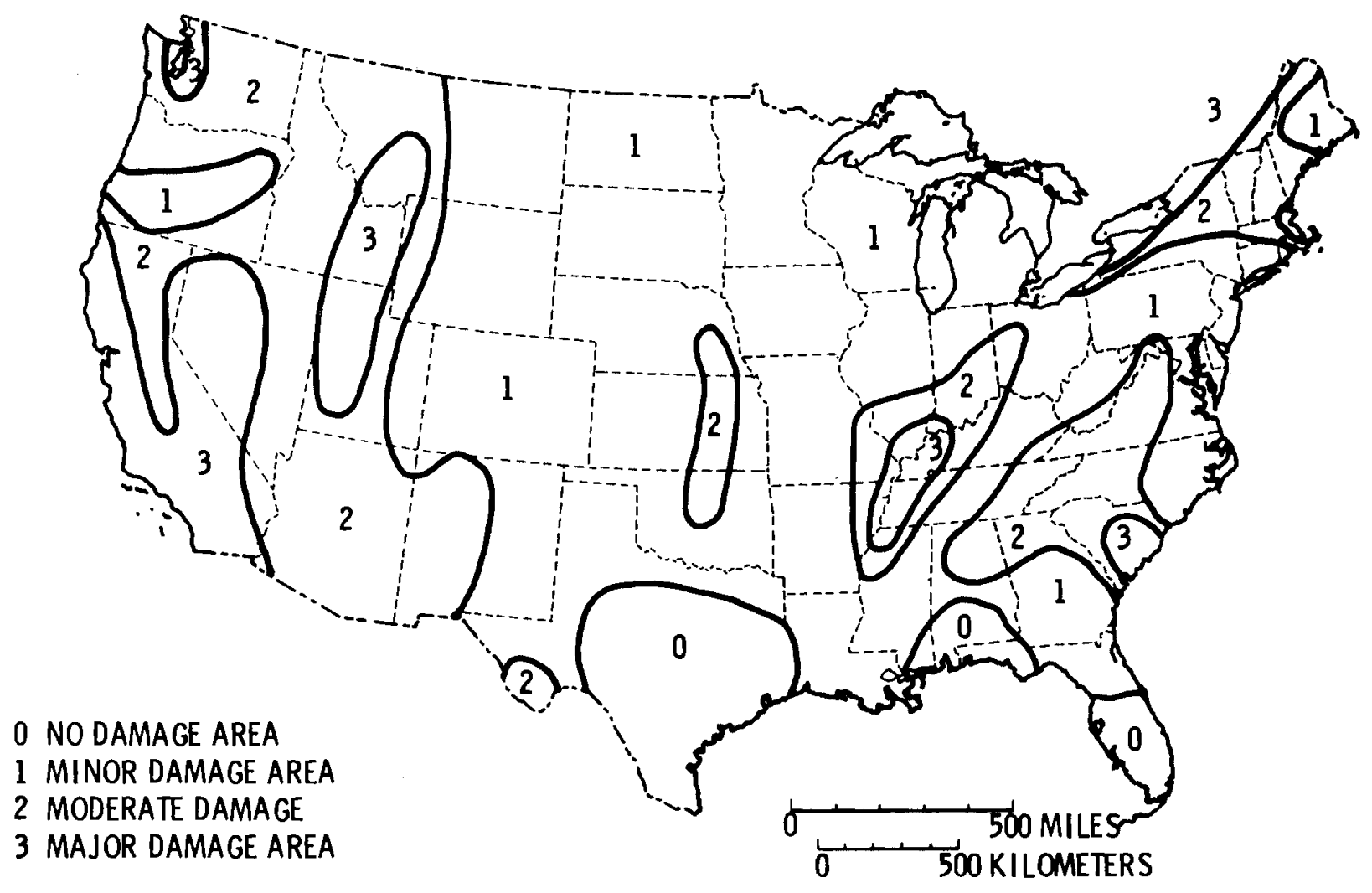

FIGURE 13. Seismic Risk Zones (Algermissen 1969)

Potential Consequences Associated with Fracturing

Before addressing the topic of occurrence probabilities, some discussion of the consequences associated with fracturing is warranted. If the anticipated consequences associated with a given geologic phenomena are within acceptable limits, then refinements of the occurrence-probability numbers may not be totally necessary.

Naturally, the consequences associated with any type of fracturing of the geologic system surrounding a nuclear waste repository will depend on the specific characteristics of the site, i.e., rock types, layer thicknesses, distribution of water-bearing zones, depth to the repository, etc. For the purpose of discussion, it will be assumed that the repository is placed in a relatively impermeable layer which may be overlain and underlain with additional low permeability buffering layers. This system is then bounded by at least two aquifer systems with differing fluid velocities and potentials. Figure 14 is an example layered model. This example is the basis for discussion. 




FIGURE 14. Example Layered Earth Mode 1 
If the host geologic formation is hardrock or shale, then the following three types of fracturing results might be considered: 1) surficial fissuring due to material loading or unloading that creates a hydraulic pathway between the repository and the 1 and surface, 2) crustal faulting that creates a hydraulic pathway between the repository and the aquifer and/or the land surface, and 3) cumulative displacement on the fault zone coupled with erosion that ultimately brings the repository into direct contact with an overlying aquifer or the land surface.

If the host rock is salt, then a fourth scenario might be included. Fracturing results in a reduction of the hydraulic buffering capacity in the "cap" and "bottom" formations, and active groundwater dissolving of the salt ultimately exposes the repository to direct leaching by saline groundwaters.

To quantify the consequences associated with any of these hypothetical situations, it is necessary to specify the characteristics of the geological and hydrological system at the time of the fracturing process and for a certain subsequent period. For example, the following should be identified: fluid potentials, hydraulic conductivities, transport pathlengths, the elapsed time since initial waste emplacement, the leachability of the waste form, the sorption or retardation characteristics of the geologic media along the flow path, the potential for "healing" of the fracture zone, and the relative displacement of the stratigraphy.

In addition, near-field phenomena such as thermally induced advective flow, hydrothermal alternations, anisotropic expansion and contraction, thermal-stress cracking, brine-density gradients, and a variety of other physical and chemical factors might be considered. For example, if a connection is somehow established between overlying and underlying water bearing strata and a repository in salt, the consequences will obviously depend on the direction and magnitude of flow. A brine-density gradient would oppose flow in an upward direction but would tend to support a downward flowing system. Furthermore, the presence of water would tend to reduce the physical strength of the salt and therefore accelerate creep closure of the flowpath. Dissolving of the salt would obviously act in favor of maintaining the opening. All of these factors should be integrated into a transport-type consequence analysis. 
One additional comment is warranted. Not all fracture systems support high permeabilities. For example, if the gouge in a fault zone is high in clay content or relative displacement along the zone has juxtaposed a shale layer against a water-bearing sandstone, the fault zone may represent a significant barrier to lateral water flow. Relative changes in water table elevations on opposite sides of the barrier might result. This may cause the inundation of a previously dry repository. The next section is a summary of some past and present efforts to quantify some of the aforementioned issues.

\section{EXAMPLES OF PAST STUDIES}

\section{Logan 1978}

S. E. Logan (1978) studied the Salado Formation in southeastern New Mexico. The model site is in a region that appears to have been stable for the last 225 million $\mathrm{yr}$. The bedded salt host formation is approximately $500 \mathrm{~m}$ thick and has a horizontal upper surface at a depth of about $300 \mathrm{~m}$. The disposal horizon is assumed to be at a depth of $800 \mathrm{~m}$, near the bottom of the formation. The overlying and underlying formations both support aquifer systems with the lower having sufficient artesian pressure to maintain a piezometric surface above the salt formation. The repository area is assumed to be $10 \mathrm{~km}^{2}$.

An aggregate probability for offset faulting sufficiently severe to fracture the bedded salt formation and connect upper and lower aquifers is given by the following:

$$
P_{F}=\frac{A_{F S}}{A_{T}} \times P_{R} \times P_{M}
$$

where

$P_{F}=$ probability of offset faulting sufficiently severe to fracture the bedded salt formation and connect the upper and lower aquifers

$A_{F S}=$ average fault surface area with movement per year

$A_{T}=$ total surface area in question 
$P_{R}=$ probability of fracture beneath repository

$P_{M}=$ probability of movement on the fault

For the area in question the probability $P_{F}$ is:

$\frac{0.012 \mathrm{~km}^{2} \mathrm{yr}^{-1}}{10^{4} \mathrm{~km}^{2}} \times 0.60 \times 0.20=1.5 \times 10^{-7}$

The average surface area with movement per year is based on a relationship between fault length and magnitude (King and Knopoff 1968) where the magnitude distribution was computed from 13 yr of historical seismic data (Sanford 1974). The probability of a fracture existing beneath a $10^{2} \mathrm{~km}$ area is estimated from limited surface and subsurface exploration in the $10^{4} \mathrm{~km}^{2}$ region surrounding the hypothetical site. The probability of movement on a fault is assigned as 0.2 . The probability range for offset faulting is given as $7.2 \times$ $10^{-7}$ to $2.9 \times 10^{-8} / \mathrm{yr}$.

It must be emphasized, however, that these estimates are for a fault displacement of sufficient severity to instantaneously expose the repository contents to ground water. The numbers do not reflect the presumably higher probability associated with rupture of relatively impermeable buffering lithologies and subsequent dissolution of the salt formation.

This particular attempt to estimate the probability of faulting in the immediate vicinity of the repository suffers a common shortcoming. The mathematical relationships are based on limited data and may or may not apply to sites different from the one for which they were derived.

Claiborne and Gera 1974

In another study of a hypothetical site in the bedded salt of southeastern New Mexico (Claiborne and Gera 1974), another somewhat controversial approach was used to estimate the probability of faulting. The following statement sumarizes the problems facing the authors in being quantitative: "In the absence of actual data on tectonic structures in the Delaware Basin, particularly buried faults in the crystalline basement and in the pre-Permian sedimentary formations, faulting in the basin will be treated as a random process" (Claiborne and Gera 1974). Two faults were identified in the area and it was 
assumed that two additional faults of similar length (18 km and $4 \mathrm{~km}$ ) would be active in the $3 \times 10^{4} \mathrm{~km}^{2}$ basin in the next $2 \times 10^{8} \mathrm{yr}$. The repository was assumed to be $8 \mathrm{~km}^{2}$ and a geometrical analysis relating the probability of a line intersecting a circular area when both are contained in a much larger area was derived to yield an estimate of a fault intersecting the repository. The resulting estimate was $4 \times 10^{-11}$ intersections/yr.

However, this value relates only the probability of a fault intersecting the repository. The probability of containment failure should be smaller because the fault would have to create a permeable fracture zone, the fluid would require a significant volumetric flow, and salt dissolution would have to outpace creep closure of the fault zone. Quantitative estimates concerning the probability of creating such a long-term, permeable path are not in the report and it is suggested that there is no current method of deriving these numbers. However, some estimates of relative displacement rates are given. A few millimeters per year is given as an appropriate long-term average for the Delaware Basin.

Bertozzi et al. 1978

In a more recent study (Bertozzi et al. 1978) the long term safety of a nuclear waste repository emplaced in a bedded salt formation in Germany is analyzed. The top of the salt bed is assumed to be $350 \mathrm{~m}$ below the land surface, and thickness and areal extent of the formation is $300 \mathrm{~m}$ and $5000 \mathrm{~km}^{2}$, respectively. Once again the system includes overlying and underlying aquifer systems, relatively impermeable boundary formations, and an essentially horizontal configuration.

The ir fault analysis assumes that the regional tectonic stresses are not compressive in nature, and therefore faulting would be exhibited as dip-slip motion on near vertical planes. The potential for reverse- or strike-slip faulting is assumed to be negligible, i.e., frequency less than $10^{-8} / \mathrm{yr}$.

The high-angle faults are classified in terms of vertical displacement, with small displacement faults having a throw of less than $100 \mathrm{~m}$. This displacement results in brittle failure of the buffering confining layers and direct dissolving of the host salt formation by groundwater. Larger faults, 
100 to $500 \mathrm{~m}$ displacement, result in fracturing of the salt layers as well as the caprock. Therefore it is assumed that a direct hydraulic flow path is created. Finally, very large displacement faults that have a throw in excess of $500 \mathrm{~m}$ are considered. The consequences of such a fault include development of a hydraulic path and sufficient uplift to bring the repository in contact with the land surface.

To compute the probability of a fault intersecting the repository, a weighted mean value of fault length is computed from a statistical distribution of observed fault lengths. The resulting average is $27.5 \mathrm{~km}$ for the study area. A geometrical analysis is then used to define a sensitivity area around the repository. It is assumed that the sensitive area increases with time, since the amount of salt dissolution that might be expected in $10^{5} \mathrm{yr}$ should be much larger than that anticipated in $10^{3} \mathrm{yr}$. The minimum time required for direct exposure of the wastes to groundwater depends on the probability of faulting and the rate of solutioning.

Figure 15 and Table 3 present sumary information of faulting frequency over the sensitive area. For the small displacement faults where the confining lithologies are brecciated and the salt is actively dissolved, time-dependent breach probabilities are derived based on: the initial volume of salt around the repository, the estimated dissolution rates, and predetermined frequency probabilities for faulting. Summary results are in Table 4.

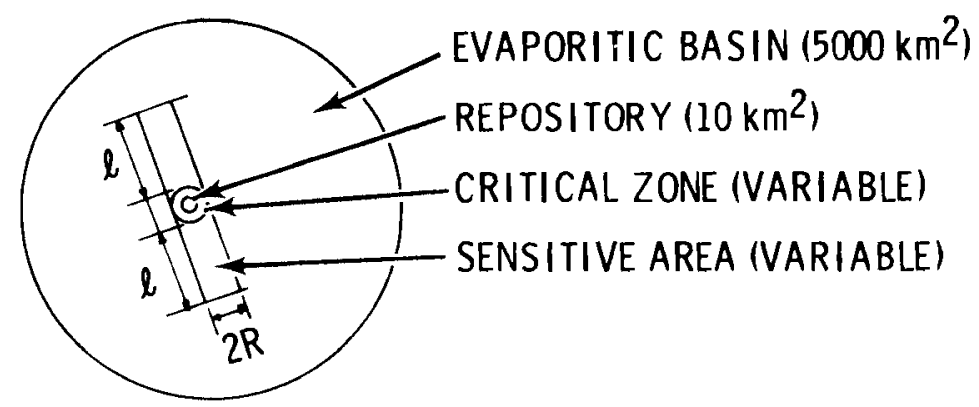

FIGURE 15. Sensitive Area About a Salt Repository (Bertozzi et al. 1978) 
TABLE 3. Faulting Frequency over the Sensitive Area Surrounding a Hypothetical Repository in Germany (Bertozzi et a1. 1978)

\begin{tabular}{|c|c|c|c|c|}
\hline $\begin{array}{c}\text { Time Span } \\
\text { for Salt } \\
\text { Dissolution, yr } \\
\end{array}$ & $\begin{array}{l}\text { Radius of } \\
\text { Critical } \\
\text { Zone, km }\end{array}$ & $\begin{array}{l}\text { Critical } \\
\text { Zone, } \mathrm{km}^{2} \\
\end{array}$ & $\begin{array}{l}\text { Sensitive } \\
\text { Area, } \mathrm{km}^{2}\end{array}$ & $\begin{array}{l}\text { Faulting Frequency } \\
\text { Over the Sensitive } \\
\text { Area, Faults/yr }\end{array}$ \\
\hline $10^{3}$ & 1.8 & 10 & 216 & $4.3 \times 10^{-10}$ \\
\hline $10^{4}$ & 1.8 & 10 & 216 & $4.3 \times 10^{-10}$ \\
\hline $10^{5}$ & 2.8 & 25 & 300 & $6.0 \times 10^{-10}$ \\
\hline $5 \times 10^{5}$ & 6.8 & 145 & 900 & $1.8 \times 10^{-9}$ \\
\hline $10^{6}$ & 12.0 & 450 & 1800 & $3.6 \times 10^{-9}$ \\
\hline
\end{tabular}

TABLE 4. Occurrence Probabilities for Faulting (Bertozzi et al. 1978)

$\begin{array}{lcccc}\text { Time, yr } & 10^{3} & 10^{4} & 10^{5} & 10^{6} \\ \begin{array}{l}\text { Probability for Small } \\ \text { Displacement Faults }\end{array} & 0 & 4 \times 10^{-7} & 4 \times 10^{-5} & 1 \times 10^{-3} \\ \begin{array}{l}\text { Probability for Large } \\ \text { Displacement Faults }\end{array} & 0 & 0 & 4 \times 10^{-6} & 1 \times 10^{-4} \\ \begin{array}{l}\text { Probability for Very } \\ \text { Large Displacement }\end{array} & 0 & 0 & 4 \times 10^{-7} & 1 \times 10^{-5}\end{array}$

Faults

Sma11 Displacement: $100 \mathrm{~m}$ vertical throw, impermeable buffering layers fractured

Large Displacement: 100 to $500 \mathrm{~m}$, salt fractured, as well

Very Large Displacement: $500 \mathrm{~m}$, total fracture system plus contact with 1 and surface.

For large displacement faults, i.e., those that rupture the salt as well as the bounding layers, a frequency of 0.10 of that for the small displacement fault frequency was chosen for time periods longer than $10^{4} \mathrm{yr}$. For time periods less than $10^{4} \mathrm{yr}$, the probability was set at zero, based on fault displacement rates. If $1 \mathrm{~cm} / \mathrm{yr}$ is an average displacement rate, then at least $10^{4} \mathrm{yr}$ are required to observe the $100 \mathrm{~m}$ of cumulative offset required for a large displacement fault. 
Summary of Current Studies at Pacif ic Northwest Laboratory

In a current study in Pacific Northwest Laboratory, the following fracturing mechanisms are being considered: 1) crustal faulting, 2) surficial fissuring, and 3) hydraulic fracturing. The following paragraphs are a summary of current observations of these phenomena.

\section{Crustal Faulting}

The PNL approach to crustal faulting is similar to that of Bertozzi (1978). However, in the European study, time was quantized into $10^{3}-, 10^{4}-$, $10^{5}$ - and $10^{6}-y r$ stages. A probability for each of the fracture types was estimated for each discrete time period. The PNL approach is to establish a "model" of the geologic system, identify the important stimuli, describe how the model will respond to each, and then conduct numerous computer simulations using 100- or 1000-yr steps. A detailed description of this technique is present in a report entitled A Conceptual Simulation Model for Release Scenario Analys is of a Hypothetical Site in Columbia Plateau Basalts, (Stottlemyre et al. 1979).

Three categories of faulting in the basement rock, faulting that may or may not rupture the overlying rock, are presented in the estimated order of their importance: 1) rupture along undetected faults, 2) rupture along known "healed" faults, and 3 ) rupture of intact rock.

An attempt is being made to relate faulting at a specific site to parameters such as the initial state of effective stress, potential changes in this state of stress, regional average strain rates, potential changes in strain rates, recorded seismicity, the initial distribution of known faults, and the material properties of the geologic system. Various models are being explored. These models vary from representing accumulated strain over a spatially distributed set of pre-existing fractures (Kehle 1979) to recurrence relationships between geologic slip rates, observable deformation, and recorded seismicity (Anderson 1978, Wight 1979). In addition, statistics on the discovery of faults during or after the construction of mines and nuclear generating plants are being reviewed. 
Estimates are being made for the probability of faulting at a given site as a function of the present state of the geologic system and as a function of potential future states of the system. In addition to estimating probabilities, it is necessary to estimate the type of fault (thrust, high angle normal, etc.), induced permeability variations, and potential displacements. For example, the unassociated seismicity (no identified fault structure) in central Washington is being analyzed. This unassociated activity is assumed to be related to undetected faults in the region.

"Starting with an average strain of $3 \mathrm{~km} / 4 \mathrm{M} \mathrm{yr}$, covering a Central Washington area of $10^{5} \mathrm{~km}^{2}$, it was estimated that there is roughly a $50 \%$ probability that an unexpected, moderately-sized earthquake would occur in any $100 \mathrm{~km}^{2}$ site area, at least once in $10^{6} \mathrm{yr}$. There are, of course, many uncertainties in an assessment of undetected faults. It is concluded, however that the probability is very high that faulting will occur in the vicinity of the repository (in the next $10^{6}$ yr)" (Wight 1979).

The probability of faulting in the immediate repository area $\left(100 \mathrm{~km}^{2}\right)$ is considered, in this isolated example, to be on the order of $10^{-6} / \mathrm{yr}$ to $10^{-7} / \mathrm{yr}$. It is therefore necessary to speculate on the type of fault and the potential consequences of any such rupture. In California where the stresses tend to be compressional on a regional scale, one would expect strike-slip faulting with little or no permeability changes along the rupture zone. In some areas of the Gulf Coast where the vertical stress is equal to or greater than the lateral stresses, one might anticipate high-angle normal or tensional faults with potentially significant permeability variations.

Another example is the Columbia Plateau region of eastern Washington where the following observations have been made: 1) the area is currently undergoing gentle north-south compression and has exhibited an average regional strain or cumulative displacement of $3 \mathrm{~km}$ in the last 4 million $\mathrm{yr}, 2$ ) below $10 \mathrm{~km}$ in depth, the area appears to support a deviatoric stress of 100 to 700 bars, 3 ) the laboratory measured ${ }^{(a)}$ shear, bulk, and Young's modulus for the basalts are 0.23 to $0.30 \mathrm{Mb}, 0.47$ to $0.65 \mathrm{Mb}$, and 0.60 to $0.80 \mathrm{Mb}$, respectively, 4) maximum observed displacement on a known high-angle reverse fault

(a) It is suggested that compressive, shear, and tensile strengths for basalt in the field be taken as $15 \%$ to $25 \%$ of the laboratory measured values to account for existing fractures. 
is $500 \mathrm{~m}, 5$ ) at least one of the topographic basins is subsiding at present, 6) the maximum rate of subsidence in the past was approximately $6.0 \times$ $10^{-3} \mathrm{~m} / \mathrm{yr}$ during the outpouring of the flood basalts some 14 to 17 million years ago, and 7) there is no evidence that would indicate a change from the present regional state of stress in the immediate future (Coombs 1979).

If the regional state of stress has a negligible probability of significant change in the next $10^{6} \mathrm{yr}$, then the type of faulting anticipated for the near future should be similar to faulting in the recent past. However, there is no guarantee that the regional or strain rate will remain constant, so speculating on the frequency and magnitude of future faulting is more difficult. Furthermore, little is currently known about induced increments in permeabilities or hydraulic conductivities that might be associated with faulting in the area. It must be concluded that, "While some relative permeability data exists for fault zones, it is by virtue of surface measurements of rupture through the surficial soil. To our knowledge, there are no in situ data describing the relative permeability of deep rock fault zones, and any conclusions would, therefore, necessarily be based on laboratory data" (Wight 1979). It is important that future study focus on this "induced permeability," because fault rupture can result in the creation of a hydraulic flowpath. Furthermore, if fluid potentials in the hydrologic system are sufficient, a significant groundwater flow rate can be established along the path. However, fault rupture and water flow along a hydraulic pathway by no means have a oneto-one correspondence. In many cases, no permeability increases along the fault zone are observed, and permeabilities perpendicular to the zone can actually decrease, thus creating a barrier to water flow.

Naturally the effects of faulting will vary according to the fundamental nature of the faulting process and the mechanical characteristics of the material being faulted. Maximum permeability changes will be developed in the upper plates of thrust faults and along normal faults. Strike-slip faults such as the San Andreas and Hayward faults in California are not noted for high permeabilities (Davis 1979).

Faulting in alluvial (sedimentary) materials commonly reduces the horizontal transmissivity of aquifers by producing gouge, localizing cementation 
by secondary minerals, reorienting fault clasts with their long axis parallel to the fault $\mathrm{pl}$ ane, and offsetting permeable beds against nonpermeable zones. Faulting in brittle rocks, on the other hand, may change local permeabilities by several orders of magnitude. Flows of large volumes of water into mines and tunnels along fault zones are widely reported in the literature. However, despite the large initial volumes of water, the flow commonly decreases rapidly because of the limited water storage capacity of fracture zones in hardrock. Even when highly fractured, these rocks will rarely store water in more than $5 \%$ of their total volume. Thus the total amount of available water contained in these hardrock permeable zones may be relatively small (Davis 1979).

In the above discussion it is assumed that the faulting is in the immediate vicinity of the repository $\left(100 \mathrm{~km}^{2}\right.$ area). However, there may also be consequences associated with an event occurring outside of this sensitive zone. It would appear that the only impact on the repository would be vibratory shaking. While this may prove to be significant during the operational phase of the repository, it appears that vibratory excitation represents a negligible hazard to a backfilled and sealed repository provided the backfill has been properly engineered. Subsurface ground motion can be one-half to two-thirds of the ground motion experienced at the surface. Therefore, it will be necessary to engineer the backfills in such a way that the material acoustic impedences are closely matched. To do this, seismic design criteria for the backfill may be necessary (Wight 1979).

Thermal loading of the repository region may result in a variety of chemical and physical reactions. For example, dissolution of rock-forming minerals such as salt, calcite, dolomite, gypsum, and silicates may increase the local bulk permeabilities by many orders of magnitude (Davis 1979). If the fluid potentials are such that the increased permeability accommodates increased water flow, then the dissolution rate is increased. It is likely that as the dissolved minerals are transported into cooler regions, the solution will become supersaturated and deposition will commence. Such deposition might tend to heal or close the flow path. In a similar manner, some hydrolytic and redox reactions can reduce permeability. A common example is the precipitation of iron and manganese oxides. Finally, creep might effectively close cracks in some rocks under elevated pressures and temperatures. Thermal loading may al so 
result in differential thermal expansion and contraction. Expansion might cause decreased permeability, whereas the cooling and contracting phase might cause dilation or opening of cracks.

\section{Surficial Fissuring}

In some parts of the country, especially the southwest, material loading and unloading can induce shallow fractures commonly termed surficial fissures. Stresses associated with large ice sheet loads in northern parts of the country may also result in some surface tensional cracking. S. N. Davis discusses this subject briefly.

Stresses giving rise to such near surface fractures could be related to differential compaction of sedimentary materials, deep dessication of sediments, changes of temperature, changes of mineral type such as the transition from anhydrite to gypsum, short term stresses from nearby earthquakes, gravitational instability during general uplift, and many other phenomena. If these fractures are caused by tensile failure and form open spaces, they are termed fissures. Fissures are most common in nonindurated sediment in valleys of the Southwest. They are widely reported from California, Arizona, and Nevada. Typically, fissures open to widths of from 5 to $50 \mathrm{~mm}$ and are afterwards enlarged by water erosion as surface runoff cascades into the fissures. Several lines of reasoning as well as 1 imited subsurface information suggest strongly that the fissures may extend downward at least $100 \mathrm{~m}$ from the surface. For periods of from 2 to $10 \mathrm{yr}$, the fissures accept impressive amounts of water and sediment and undoubtedly from efficient channels for ground-water recharge. Some fissures having lengths of less than $100 \mathrm{~m}$ have received more than $10^{7} 1$ of water during a single storm event.

Somewhat related is the concept of surficial fracturing due to glacial loading and subsequent isostatic rebound. In a discussion on the subject, Bull (1979) cites work by Brotchie and Silvester (1969) and Peltier and Andrews (1976). In these studies of the deformation of the earth's crust under superimposed ice loads, the authors conclude that the tensional stresses near the edge of large ice sheets may be sufficient to cause surface fracturing. In a separate study, Weertman (1978) calculates stresses in the range of 30 to 300 bars from loads associated with Laurentide ice sheet.

Bull continues by stating that stresses are greatest at the edge of the ice sheet and that both the radial and tangential stresses appear sufficient to result in fracturing. Fracturing thus caused, may be responsible for the 
formation of the Great Lakes, the Finger Lakes, and other water bodies marginal to the large ice sheets. Some of these lakes are radial to the ice sheets, others, tangential. Faults along the coast of Maine, probably initiated by similar ice sheet stresses, are still active due to isostatic rebound.

\section{Hydraulic Fracturing}

Another potential fracture mechanism is hydraulic fracturing. Such extension fractures are found in a wide variety of geologic settings. Typically these cracks are filled with fluid (e.g. water, oil, gas) and it appears that fluid pressures and pressure gradients have played an important role in dilation and propagation of the fractures.

One example of man caused extensional fracturing is hydro-fracturing which is a common method of stimulating flow in wells. A conservative assumption is that many geologic materials have negligible tensile strength due to inherently weak aggregation or pre-existing but closed fracture. Theory suggests that if the interstitial or pore fluid pressure is increased to the magnitude of the minimum principal stress, (a) then the material is fractured in a dilational mode with the fracture plane orientation being basically perpendicular to the minimum principal stress. Some effort is necessary to quantify the probability of man-caused fluid potential changes caused by secondary oil recovery, waste fluid disposal, large irrigation or reservoir projects, and so forth. In addition, some estimate of the magnitude of the induced permeabilities should be made.

Natural phenomena may also result in abrupt increases in subsurface fluid pressures. Such changes could be produced by local ponding of rivers, changes in ocean levels related to world-wide glaciation, erosion of sediments in river valleys, changes in rainfall and advancement of continental ice sheets (Davis 1979). It may be possible to demonstrate, however, that virtually all natural changes would be slow enough to permit equilibrium without the development of

(a) In areas such as California, which is undergoing active tectonic compression, the lateral stresses tend to exceed the vertical stress and the minimum principal stress is vertical. In other areas like the interior Gulf Coast, the state of stress can range from hydrostatic (al1 stress components equal) to extensional (vertical stress exceeds the lateral stresses). 
large transient pressures. It has been suggested that hydraulic gradients in excess of 0.3 are not likely (Davis 1979). The exceptions may be glacial loading and natural geopressurized zones similar to those found in some parts of the Gulf Coast.

\section{Summary}

- The type of fractures being considered include: hydraulic fractures caused by changes in interstitial fluid pressures, surficial fissures caused by material loading or unloading, and faulting due to compressional or extensional stresses. This includes rupture on undetected faults, known "healed" faults, and virgin intact rock.

- The type of faulting, normal, reverse, thrust, or strike-slip, depends on the state of effective stress in the area.

- Sea-floor spreading and plate tectonics help explain faulting in the vicinity of plate boundaries. However, intraplate seismicity is not well understood, but is infrequent.

- The primary release scenario involves creation of a hydraulic pathway, significant groundwater flows, and continual replacement of the fluid in the source aquifer.

- If a hydraulic path is developed, the following information is necessary to quantify the consequences: 1) time of the breach relative to waste emplacement; 2) pathlength to the biosphere, hydraulic conductivities along the path, 3) fluid potentials, and 4) sorption characteristics along the path.

- Thermally induced advective flow, hydrothermal alterations, thermal stress cracking, salt density gradients, and other physical and chemical interactions should be considered.

- Fault zones may be barriers to as well as conduits for the flow of water. The result could be inundation of the waste without significant flow through the repository. 
- Estimates for faulting in an area should be based on the state of effective stress, the material properties, recorded seismicity, observable cumulative deformation in the region, average strain rates, and anticipated changes in regional strain rates.

- Surficial fissures can extend for 100 or more meters into the ground and can accept significant amounts of water for a 2 to 10 -yr period.

- Radial and tangential fracturing due to continental ice loading, may be a possibility near the margin of 1 arge ice sheets.

- Potential consequences associated with fractures include: 1) creation of a hydraulic pathway and perturbations of fluid potentials, 2) creation of a barrier to lateral groundwater fluid and subsequent changes in the water table, and 3) vibrational ground motions, which may be insignificant if the backfill material is properly engineered. 


\section{SURFACE HYDROLOGIC CONSIDERATIONS}

Hydrologic factors desirable for a waste repository include: 1) low interstitial and fracture permeability, 2) high effective porosity or storage capacity, 3) low fluid potentials or hydraulic gradients, 4) lengthy flow paths between the repository and the biosphere, and 5) high retardation or sorption characteristics of the geologic media. These characteritistics are all subject to change and some prediction of the likelihood, magnitude, and rate of change is necessary for an assessment of long-term safety.

Ignoring for the moment the potential retardation of wastes by interaction with the geologic media, it is possible to present the remaining four factors in a simplistic mathematical form known as Darcy's Law.

$$
v=\frac{-k}{n_{e}} \frac{h}{T}
$$

where $V$ is the average velocity of the fluid, $k$ is the intrinsic permeability, $n_{e}$ is the effective porosity, and $h / l$ is the fluid potential or hydraulic head gradient. Throughout this report fluid potential or hydraulic gradient values are given as dimensionless numbers, for example a gradient of $0.005 \mathrm{~m} / \mathrm{m}$ is given as 0.005 . In a given increment of time, an incremental volume of water will move an average distance that is the product of the velocity and time. This is a crude measure of how $f$ ar long-lived radionuclides might be transported, assuming the velocity field is uniform both in time and space (Bredehoeft et al. 1978). For example, since the desired transport path length is $\leq 1000 \mathrm{~m}$ in $100,000 \mathrm{yr}$ and porosity is 0.10 and the gradient is 0.01 , it is necessary that:

$$
V=\frac{\mathrm{d}}{\mathrm{t}}=\frac{1 \times 10^{3} \mathrm{~m}}{105 \mathrm{yr}}=1 \times 10^{-2} \mathrm{~m} / \mathrm{yr}=3 \times 10^{-8} \mathrm{~cm} / \mathrm{sec}
$$

and

$$
k=-v_{\text {ne }}\left(\frac{1}{h}\right)=\left(3 \times 10^{-8} \mathrm{~cm} / \mathrm{sec}\right)(0.1)\left(\frac{100}{1}\right)=3 \times 10^{-7} \mathrm{~cm} / \mathrm{sec}
$$

Thus, the hydraulic conductivity along the flow path should be approximately $3 \times 10^{-4}$ Darcys (Bredehoeft et al. 1978). For a million years, this becomes 
$3 \times 10^{-5}$ Darcys. Table 5 and Figures 16 and 17 lend perspective to representative permeability values for geologic media. Values of $3 \times 10^{-5}$ Darcys are not difficult to obtain. The primary objective of this section of the report is to address how permeabilities, fluid potentials, effective porosities, and transport pathlengths might vary at a given site in the future.

Many natural and man-caused phenomena can be cited as potential factors. For example, crustal faulting, surficial fissuring, hydraulic fracturing, climatic variations, denudations and stream erosion, sea level fluctuations, glaciation, irrigation, and fluid waste disposal must all be considered in this highly coupled, and in many cases poorly understood, system. Actual prediction of how these phenomena will change a given site over the next $10^{6} \mathrm{yr}$ is not compatible with existing technology. However, it may be possible to address the variety of scenarios that might occur at the site and to bound in a probabilistic manner the likelihood, magnitude, and rates associated with various changes to the geologic and hydrologic system.

TABLE 5. Representative Values of Permeability for Natural Materials (Courtesy of S. N. Davis, University of Arizona)

\section{Description}

Chert, Precambrian

Mica schist

Rock salt

Gypsum

Silt, Pascagoula Formation

Sandstone, Catahoula Formation

Tuff, friable

Dolomite

Sandstone, friable

Sand, alluvial

Sand, course

Limestone, Biscayne aquifer
Permeability, Darcys

$1.1 \times 10^{-7}$

$2.1 \times 10^{-6}$

$7.3 \times 10^{-6}$

$3.1 \times 10^{-5}$

$3.8 \times 10^{-5}$

$5.5 \times 10^{-4}$

$1.4 \times 10^{-3}$

$1.6 \times 10^{-2}$

$3.6 \times 10^{-1}$

2.2

55.0

1600 


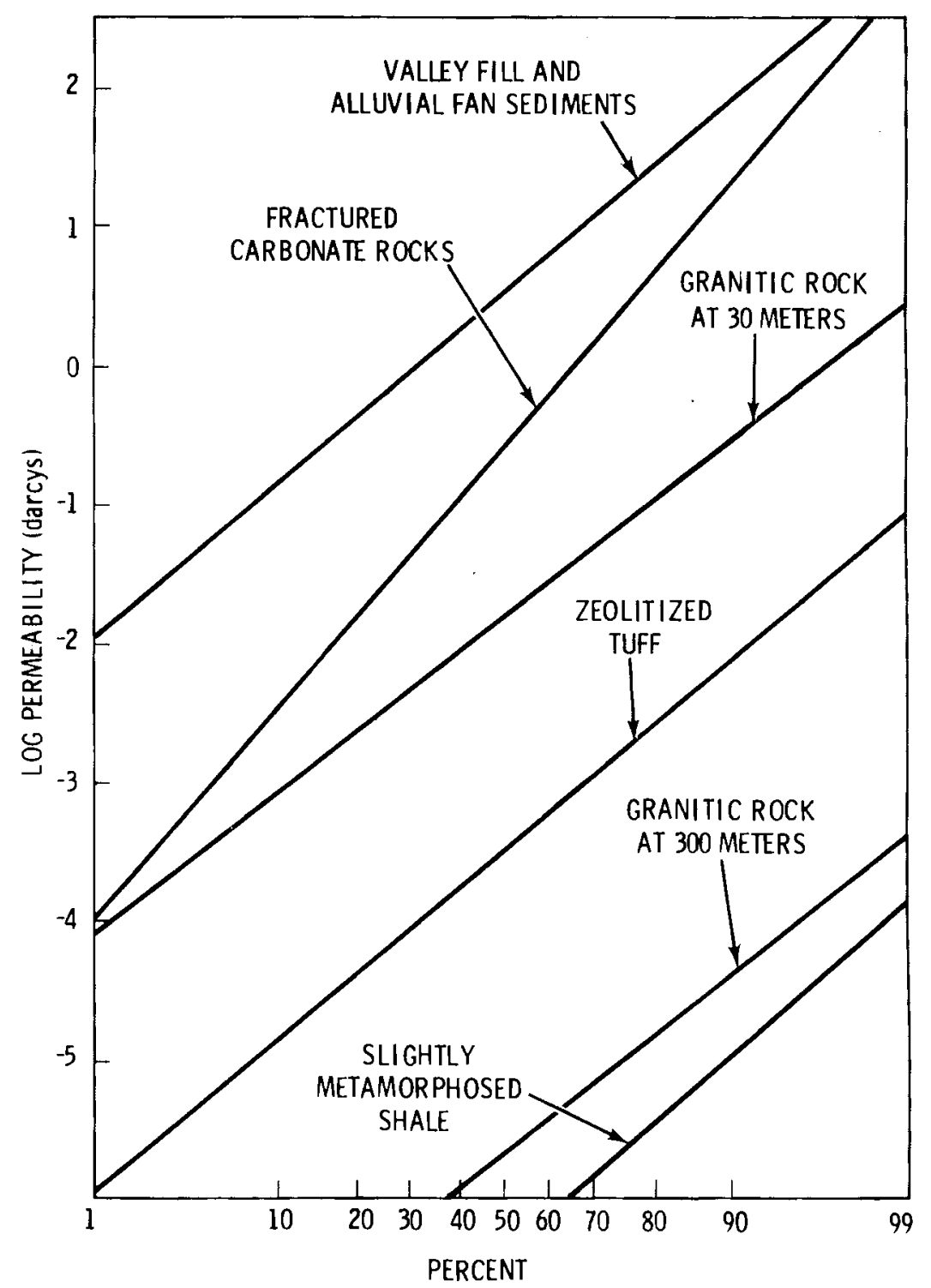

FIGURE 16. Typical Permeabilities of Basin and Range Province Rock (Courtesy of S. N. Davis, University of Arizona)

We have already seen how the fracture permeability can vary due to crustal faulting, surficial fissuring, and hydraulic fracturing. Obviously, if the permeability of the system is increased, the potential for volumetric flow of groundwater will also increase. However, there must exist a hydraulic head gradient that can maintain the flow. Creation of a hydraulic pathway does not necessarily indicate a steady-state flow of water along the path, nor does it indicate that contaminated fluid reaches the biosphere. 


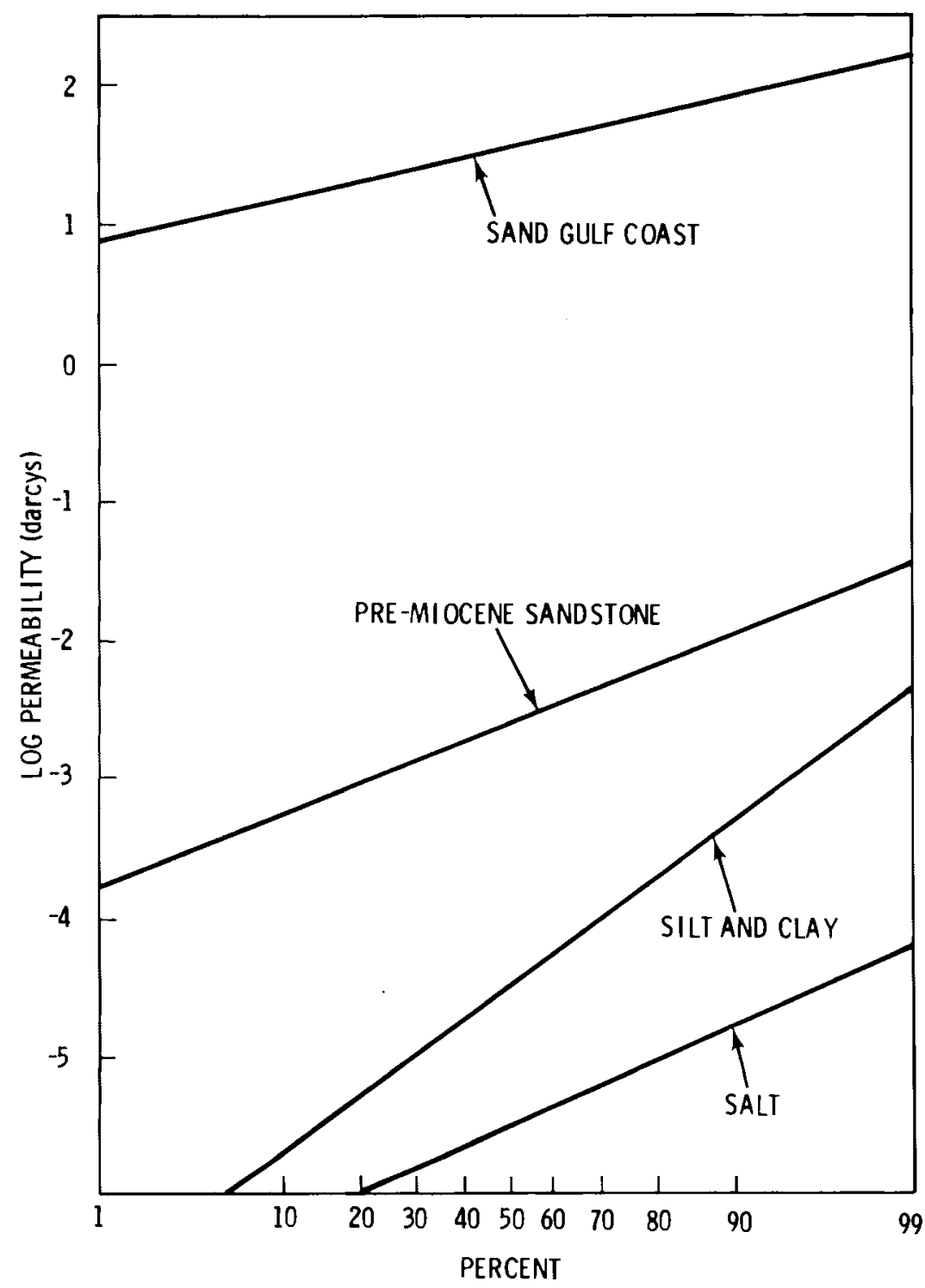

FIGURE 17. Representative Permeabilities of Gulf Coast Materials (Courtesy of S. N. Davis.)

\section{Igneous Rocks}

Igneous rocks, such as granite, are generally brittle and susceptible to fracturing. Weathered and highly fractured granitic material near the land surface can support effective porosities and permeabilities approaching $30 \%$ and 1.0 Darcy. Both porosity and permeability rapidly decrease with depth for typical pressure and temperature conditions. Effective porosity at a depth of 
$300 \mathrm{~m}$ in typical granitic stocks in the Basin and Range (physiographic) Pro-

vince is certainly less than $0.5 \%$ and may be less than $0.1 \%$ (Davis 1979). Consequently, unless the induced fractures intersect aquifer systems overlying the granitic stock, the source of water available for waste transport will be rapidly depleted. Even when highly fractured, granitic rocks will rarely store more water than $5 \%$ of their total volume. Thus, the total amount of water contained in these permeable zones may be relatively small, and the flow will commonly decrease rapidly with time (Davis 1979).

Experience in mines and tunnels reveals that permeable fault zones can be excellent steady-state water producers even at depths greater than $300 \mathrm{~m}$ and in some places greater than $1000 \mathrm{~m}$. Three fundamental criteria appear necessary to support such long term flow. First, the fracture must have produced asperity offsets or gouge of sufficient strength to keep the cracks open against the confining lithostatic pressures at depth, e.g., approximately 130 bars at $600 \mathrm{~m}$ depth. Secondly, the fault or fracture zone must have intersected a significant source of water such as an aquifer system superimposed on an igneous intrusion. Finally, a water sink is necessary. The tunnel or mine, being at near atmospheric pressure, provides an excellent sink or low potential discharge point. But a backfilled and sealed repository may or may not form such a sink. A second possibility is that another aquifer system is intersected and that a head differential between the lower and upper water bearing zones will cause flow between the zones.

Figure 18 illustrates such a system for a granitic stock in the Basin and Range Province. It can be seen that the source of water is at the 1 and surface or in shallow alluvium and that the sink or discharge point is in the porous carbonate rocks at depth. S. N. Davis points out that field measurements of the dispersivity of granitic rocks have not been made. He estimates, however, that longitudinal and lateral dispersivities between 10 and $200 \mathrm{~m}$ might be expected.

\section{Salt Domes}

Geometrically, salt domes might be considered analogous to the granitic stocks just discussed. A conceptual model is presented in Figure 19. The question of where the water sink might exist is equally valid for salt domes 


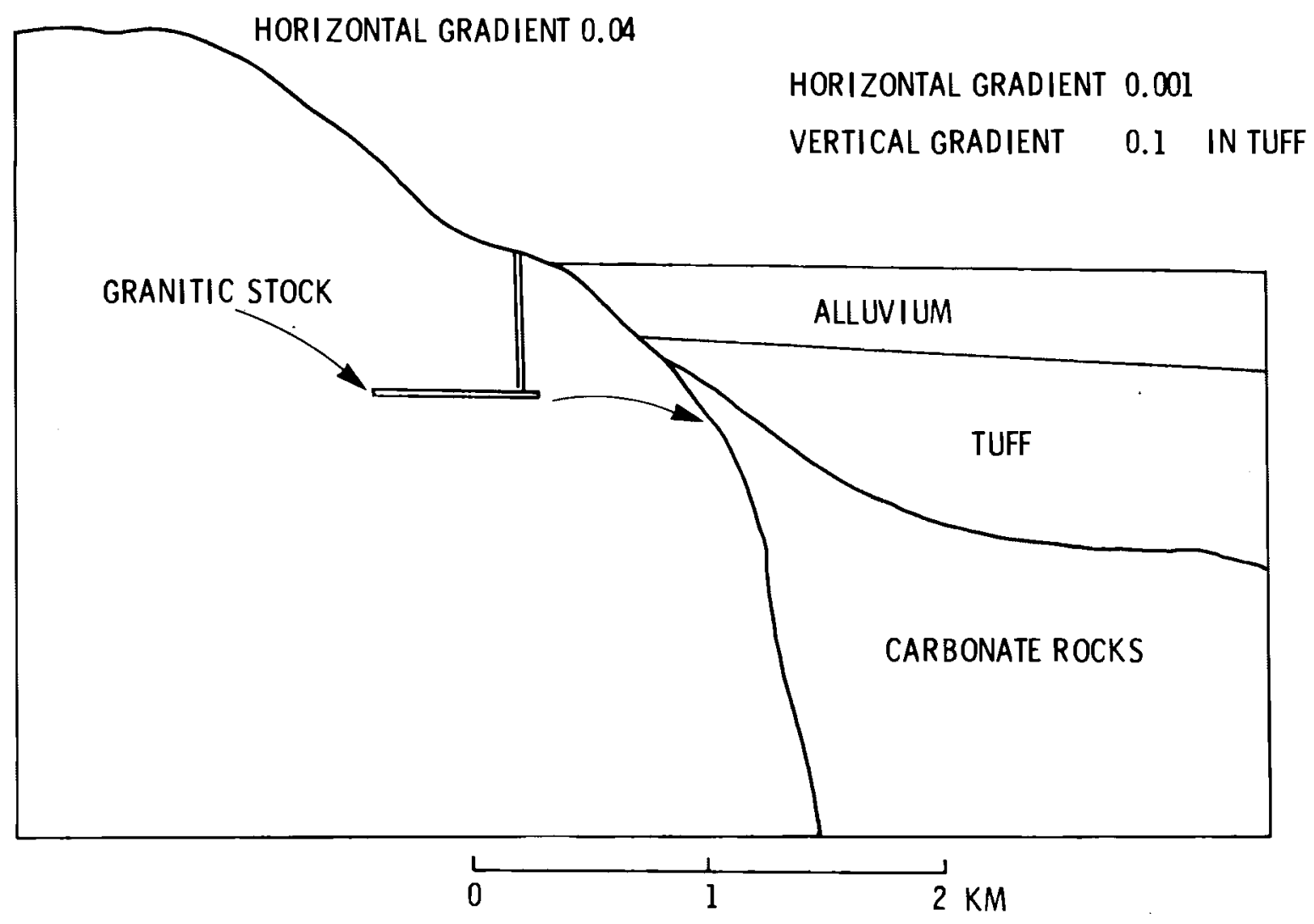

FIGURE 18. Basin and Range Granitic Stock (Courtesy of S. N. Davis, University of Arizona)

since high permeability zones do not exist directly below the dome but are on the flank. Unlike granite, however, it is difficult to envision how an induced fracture system could remain open in salt, due to its plasticity at low strain rates and the signficiant lithostatic pressures and temperatures postulated for a repository. It would appear that active solutioning of the salt bounding the fracture would be required to maintain an open flowpath. Such dissolution requires the aforementioned source-sink system with a sufficient hydraulic gradient between the two, and brine that is not already saturated by total dissolved solids.

Ignoring man-caused dissolving for the moment, a more realistic scenario for salt formations might involve fracturing of the relatively low permeability caprock material (shale, anhydrite, gypsum, etc.), slow circulation of groundwater from an overlying aquifer into one of the adjacent sedimentary aquifers, 


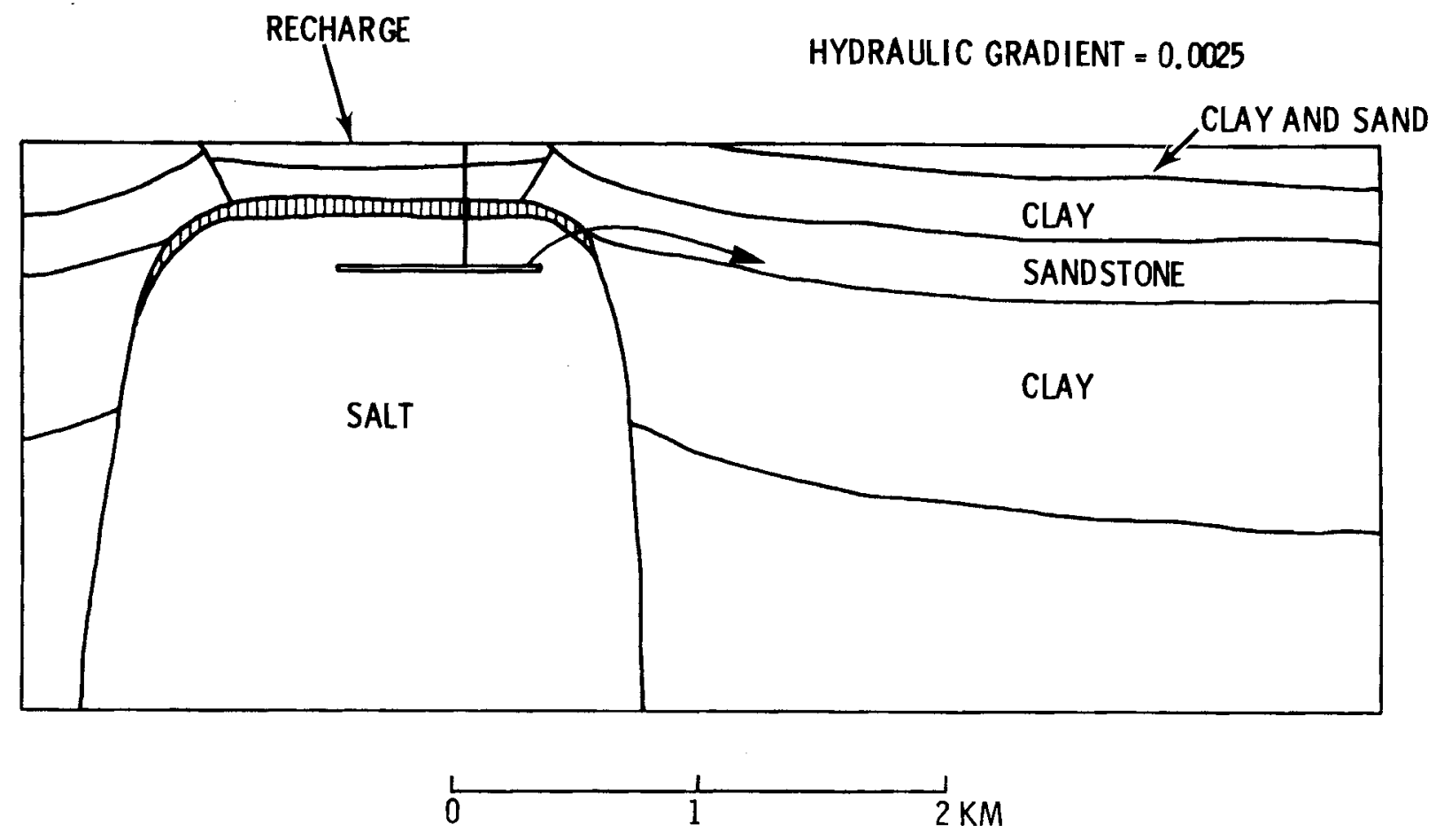

FIGURE 19. Conceptual Mode1 for a Salt Dome (Courtesy of S. N. Davis, University of Arizona)

and subsequent solution collapse with the cap reduced to rubble. This might lead to continual dissolving of the salt at the top or the flanks of the dome and exposure of the repository. A flow path through the salt is not required and therefore the subject of fracture healing is not particularly relevant. Water would actually be flowing in an ever-increasing gap between the salt and the stronger caprock. If the stress difference across the caprock should then become large enough, solution collapse of the system would be the result. Many cases of such solution collapse are documented, especially the wildcat brining operations of the early 1900s. As Davis points out, such salt dissolution collapse might result in the discharge of nuclides into the sedimentary aquifers that support porosities of from $15 \%$ to $35 \%$, longitudinal dispersivities of between 15 and $35 \mathrm{~m}$, and transverse dispersivities of perhaps 5 to $50 \mathrm{~m}$ (Borg et al. 1976). Fortunately the suggested rates for such natural dissolution of salt are slow enough so that exposure of a properly buffered repository should not occur for tens of thousands of years. 


\section{Bedded Salt}

Figure 20 is a conceptualization of a repository in bedded salt in southeastern New Mexico. The main differences between this and a salt dome are that: 1) the beds are less thick but wider, 2) bedded salt formations can have both overlying and underlying aquifer systems, 3) the impurities and interstitial water contents are greater for bedded salt, and 4) the alternate uses appear to be less for bedded formations.

The two primary natural disruptions are still dissolution and fracturing. Natural dissolution rates have been estimated at 0.002 to $2.00 \mathrm{~mm} / \mathrm{yr}$. Naturally, man-caused dissolution would be exceedingly rapid. Fracturing of a bedded salt formation has al ready been discussed in the synopsis of the Logan, Claiborne, and Bertozzi studies.

Under existing climatic conditions, if either of the aforementioned scenarios occurred (fracturing and/or active dissolution), water from the over7 ying aquifer would slowly flush through the repository from upgradient to downgradient (Davis 1979). The discharge point would probably be the sandstone and carbonate formation below the host salt formation. Davis points out that the water in this discharge zone is quite saline and therefore its value to man is questionable.

HORIZONTAL HYDRAULIC GRADIENT 0.0005

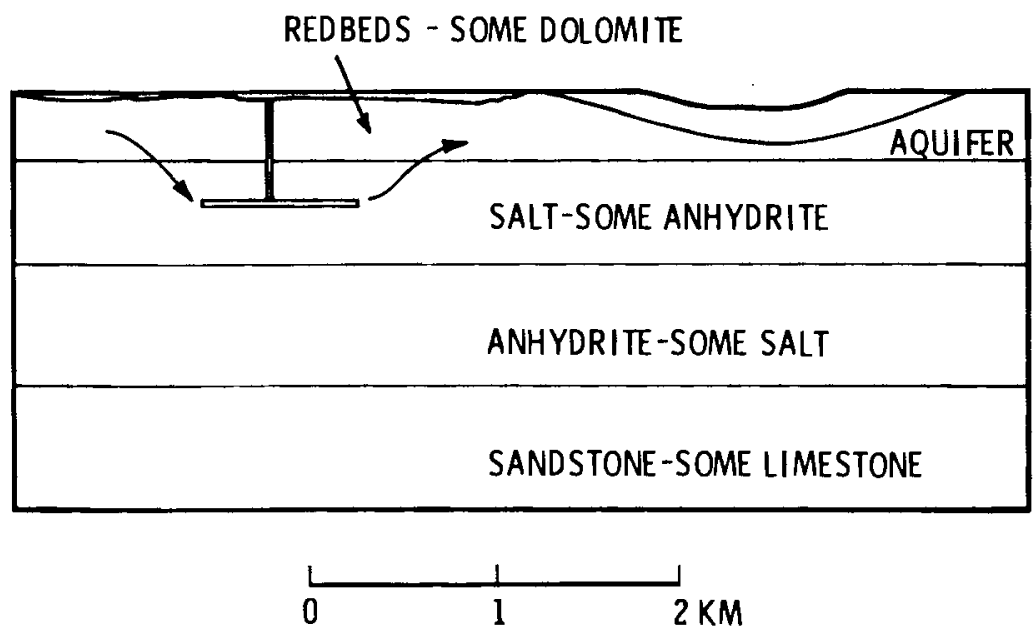

FIGURE 20. Conceptual Model for a Bedded Salt Formation (Courtesy of S. N. Davis, University of Arizona) 


\section{Basalt}

Figure 21 represents a repository in a basalt formation. The previous discussions concerning the requirements for a water source, creation of a fracture flow path, and a water sink also hold true for a layered basalt system. Note that, once again, it is necessary to estimate the fluid potential differences in the bounding aquifer systems in order to quantify the direction and magnitude of groundwater flow through a basalt repository. It has been suggested that offset faulting could conceivably increase the permeability in the basalt by as much as two orders of magnitude and that mineral dissolution might enhance this effect. However, in the Columbia Plateau region of eastern Washington, examples can be found where the fracture system is actually a barrier to water flow. This is due to the nature and orientation of the fault gouge or to the offsetting of high permeability beds against low permeability beds

FUNDAMENTAL VARIABLES

F(TIME, SPACE)



FIGURE 21. Conceptual Model of a Repository in Basalt 
on opposing sides of the fault zone. Details on Columbia River Basalts region are available in a report entitled A Conceptual Simulation Model of Release Scenario Analysis of a Hypothetical Site in Columbia Plateau Basalts, (Stottlemyre et al. 1979).

\section{Possible Changes in Fluid Potentials}

This qualitative discussion has thus far centered around granitic, salt (bedded and domed), and basalt hydrologic systems as they exist today. The fundamental objective of the release scenario analysis is to estimate how characteristics such as fluid potentials, permeabilities or transmissivities, and transport pathlengths can change over tens or hundreds of thousands of years.

Several factors of interest of changes in fluid potentials include: 1) an increased infiltration at existing recharge points, 2) a spatial change in recharge and/or discharge locations, 3) a change in the elevation between recharge and discharge points, 4) an inundation of the repository site or recharge areas by a surface water body, 5) perturbations of groundwater flow patterns due to offset faulting, 6) removal of a low permeability layer, 7) the creation of new flow paths that change the potentials. Naturally, climatic, geomorphological, tectonic, glacial, and man-related phenomena are all potentially involved. Each of these phenomena will be subsequently discussed. The remainder of this section will be devoted to examples illustrating how changes in fluid potentials might be quantitatively bounded at some repository sites.

Gulf interior salt domes under consideration as waste repositories are typically 150 to $300 \mathrm{~km}$ inland from the present shoreline of the Gulf of Mexico. The hydraulic gradient in the regional aquifers should not be increased by more than about $30 \%$ in the event of a $100 \mathrm{~m}$ drop in the ocean level. This is because as the water level decreases, the shoreline will rapidly migrate south and any added hydraulic head differences between the salt domes and the new shoreline will be offset by the increased path length. Conversely, if all the world's ice caps were to melt and the ocean level increase by as much as $100 \mathrm{~m}$ and inundate a dome, all hydraulic gradients would be reduced to very low values, i.e., 0.005 or lower. 
The hydraulic gradients of aquifers shallower than about $100 \mathrm{~m}$ could be increased up to $100 \%$ because of a three- or four-fold increase in precipitation. Thus, the fluid velocities in these aquifers could realize a two-fold increase. Aquifers below about $100 \mathrm{~m}$ should not be significantly affected by increased rainfall or impounded water at the surface (Davis 1979). A decrease in Gulf Coast rainfall would cause a decrease in shallow aquifer gradients, but little change to the deeper ones.

An increase in the depth to base level and thus an increase in hydraulic gradients might be caused by erosion. In the Gulf Coast, a $15 \mathrm{~m}$ lowering of the base level occurred several times during the Pleistocene. This erosion would provide head drops sufficient to increase hydraulic gradients in nearsurface aquifers by $40 \%$ to $60 \%$. Aquifers below a few hundred feet will probably be affected by surface erosion by less than 10\% (Davis 1979).

Fault offset of 1 to $10 \mathrm{~m}$ in the Gulf Coast region might create total or partial barriers to groundwater flow. This could occur due to the offsetting of permeable sands against relatively impermeable clays. Such flow barriers might change the water table and flow patterns on each side of the zone.

With respect to the bedded salt sites of New Mexico, climatic variations could have significant effects on the groundwater potentials. Shallow, discontinuous bodies of alluvium and dune sand could become saturated if rainfall tripled or if evapotranspiration were much lower. Based on existing topography, the average hydraulic gradients in the Culebra dolomite could increase from about 0.005 to about 0.007 . Naturally changes in recharge or discharge locations or relative elevations would significantly modify this estimate.

A drastic increase in precipitation might increase local hydraulic gradients in the Basin and Range Province around the Nevada Test Site. Davis points out that if water levels rise so that standing water appears in Yucca Flat, the total head drop between Yucca Flat and the regional discharge in Ash Meadows, some miles away, will increase by at least $450 \mathrm{ft}$. The present head drop is only about 45 to $60 \mathrm{~m}$. It appears that a major part of the head drop would be in the tuff formation, not in the carbonate aquifer. A two-fold increase in the groundwater flow velocity is possible, but a four-fold increase appears unrealistic. 
In all cases, an increase in local precipitation does not signify a similar increase in groundwater recharge. The amount of fluid that a permeable layer can accept in a unit amount of time depends on the infiltration rate, the infiltration capacity, and the pressure under which the water is applied to the recharge point. It is analogous to pouring water into a funnel. One can pour the water faster than the funnel can drain and runoff will result. In a similar fashion, increased rainfall on a recharge area will cause some increased groundwater recharge, but once the infiltration capacity is reached the increased precipitation will be surface runoff. If a lake is superimposed on the recharge point, the depth of the lake will determine the recharge pressure and the surface water - groundwater system will ultimately attain equilibrium. This new equilibrium can be defined by the volumetric flow in the aquifer and the depth of the lake.

A hypothetical hydrologic system for the Columbia Plateau basalts will be given in a final example. Some example hydrologic characteristics of the Columbia Plateau Basalts are shown in Table 6 . One natural phenomenon that must be considered for this area is continental glaciation. A detailed discussion of glaciation is presented in the next section on geomorphology, however it can generally be asserted that the Pasco Basin has not been glaciated in the recent past but has been the site for large inter-and post-glacial flooding episodes and temporary lakes. Such a lake, possibly as deep as $300 \mathrm{~m}$ would quickly increase the elevation of the unconfined water table, but the uppermost basalt layer should buffer the underlying confined aquifers from this surficial recharge.

The Columbia Plateau has been near the edge of several continental glaciers. Therefore it is necessary to consider the possibility of groundwater recharge during future episodes of continental glaciation. Under glacial loading, the surface boundary conditions for recharge may be appreciably altered. This is due to the weight of the ice and the presence of water at the base of the ice sheet. In general, this water would be under a pressure equal to $0.09 \mathrm{bars} / \mathrm{m}$ of ice thickness. Free water would exist over appreciable areas of the ice sheet beds and nearly all of this water, 0.5 to $3.0 \mathrm{~cm} / \mathrm{yr}$, would be available for recharge (Bull 1979). Bull also points out that although the 
TABLE 6. Example Hydrologic Characteristics for an Area in the Columbia Plateau Region (Courtesy of M. D. Veatch, Veatch, Shannon and Wilson, Inc.)

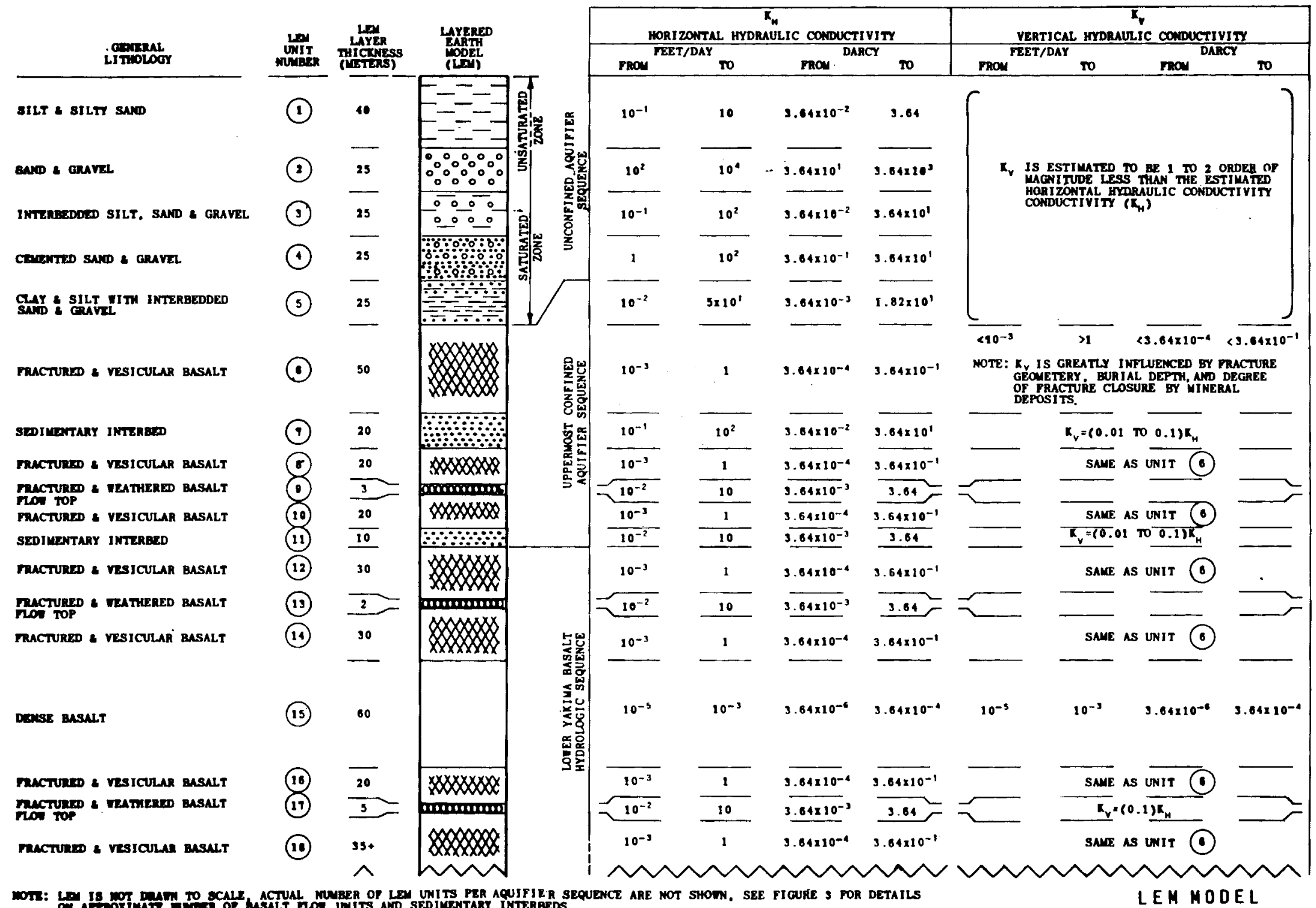


total annual precipitation currently exceeds $3 \mathrm{~cm}$, the recharge may be greater under glacial conditions because of all-year recharge, surface pressure conditions, and negligible evaporation.

Deep recharge under an ice sheet is not likely to affect sites in places like Louisiana or New Mexico, because of their isolation from continental ice. However, under extreme alpine glacial conditions or a more extensive Cordilleran ice sheet, the Salina Basin and the Columbia Plateau might be affected to some degree (Bull 1979). Note however, that groundwater recharge of regional aquifers does not necessarily mean that hydraulic communication between aquifers is increased. It is still necessary to devise a flow path through the low permeability layers containing the repository.

\section{Summary}

Estimating how hydrologic parameters might change from their current status at any given site is an important element of a long-term safety assessment program.

- Hydrologic factors desirable for a waste repository include: 1) low permeability, 2) high effective porosity, 3) low fluid potentials, 4) long flowpaths, and 5) high nuclide retardation or sorption characteristics.

- These characteristics are subject to change at a given site, especially within $10^{6} \mathrm{yr}$. An estimate of the probability, magnitude, and the rate of change of the characteristics is necessary.

- For a zone with a $10 \%$ porosity and a hydraulic gradient of 0.01 , a permeability of $3 \times 10^{-4}$ darcy is desirable. To limit water migration to less than $1 \mathrm{~km}$ in $10^{5} \mathrm{yr}$, a permeability of $3 \times 10^{-5}$ is necessary for $10^{6} \mathrm{yr}$.

- Fluid potentials can be affected by crustal faulting, surficial fissuring, hydraulic fracturing, climatic variations, denudation, stream erosion, sea level changes, glaciation, irrigation, and fluid waste disposal. 
- Accurate prediction of how the hydrologic characteristics at a given site will change over the next $10^{5}$ to $10^{6} \mathrm{yr}$ is not currently possible. However, it may be feasible to identify the various ways that geohydrologic systems could be altered and to bound magnitudes and rates in a probabilistic manner. In this way one would have a set of possible future configurations of the geology and hydrology. The priority in analyzing the states of hydrology and geology would depend on their relative occurrence probabilities and their anticipated consequences.

- Brittle fracture of granitic or basaltic rocks does not necessarily dictate signficant groundwater flows along the path: the source of water may be quickly depleted. An aquifer or surface water must be intersected, if flow is to be maintained.

- In addition to a continuous water source and creation of a fracture flow path, a potential sink such as a mine, tunnel, or second aquifer at a different dynamic head is necessary for a significant flow system to exist. If the source is also the sink, then the fluid column may be essentially static, subjected to thermally induced advection or influenced by density and concentration gradients.

- Fracture systems need not remain open indefinitely. Creep closure in salt and mineral redeposition in hardrocks may heal the fractures. Similarly, under the lithostatic pressures at depth, fracture gouge or asperities are necessary to keep hardrock fractures open.

- With respect to salt, fracturing of the caprock or bottom rock and the slow dissolving of the salt is the most realistic scenario leading to groundwater transport of wastes. Solution collapse is also a distinct possibility.

- Natural dissolution rates of from 0.002 to $2.0 \mathrm{~mm} / \mathrm{yr}$ are reported in the literature.

- Fluid potentials might be affected by: 1) pressurized recharge, 2) a relative change in the location and/or elevation of recharge or 
discharge, 3) inundation by a surface water body, 4) offset faulting, $5)$ the removal of low permeability barriers, and 6) the creation of new fracture flowpaths.

- A 100-m drop in ocean level might increase the fluid potentials in shallow Gulf Coast aquifers by $30 \%$.

- An ocean level increase of $100 \mathrm{~m}$ might inundate some coastal salt domes, but hydraulic gradients in aquifers would be reduced to values of approximately 0.005 or lower.

- A significant increase in precipitation (300\%) could cause a two-fold increase in hydraulic heads in shallow $(<60 \mathrm{~m})$ aquifers. Deeper Gulf Coast aquifers should not be significantly affected.

- The lowering of discharge points by erosion (by an estimated $15 \mathrm{~m}$ for the Gulf Coast) might increase fluid potentials in shallow Gulf Coast aquifers by as much as 40 to $60 \%$. Deeper aquifers should not be affected by more than $10 \%$.

- Offset faulting of 1 to $10 \mathrm{~m}$ in the Gulf coast area could create barriers to lateral groundwater flow, especially if permeable sands are set against relatively impermeable shales.

- Increased rainfall in southeastern New Mexico might increase the gradients in the Culebra aquifer from 0.005 to 0.007 if surface topography were to remain constant with time.

- At the Nevada Test Site, a two-fold increase in hydraulic head in the carbonate aquifers is likely to result from a major increase in precipitation.

- Increased rainfall and groundwater recharge are not on a one-to-one correspondence. Much of the excess liquid becomes impounded surface water or river runoff. 
- If it should occur, continental glaciation or prolonged lake impoundment in the vicinity of the Pasco Basin could increase subsurface recharge in the regional aquifers. However, increased flow in the interbeds and other aquifers does not necessarily indicate flux through any given basalt layer. Creation of a fracture flow path may still be necessary. 


\section{MAGMATIC ACTIVITY}

$\underline{\text { INTRODUCTION }}$

Most active volcanoes are located in the proximity of crustal plate boundaries which are generally areas of high seismicity (Figure 22). However, midplate volcanism is possible, both in oceanic and continental areas. About 62\% of all volcanoes active in history are in the circum-Pacific "circle of fire"; about $14 \%$ of these are in the Indonesian Island arc. Only $24 \%$ are located throughout the rest of the world. Of these, $3 \%$ are in the islands of the central Pacific, $1 \%$ on the islands of the Indian Ocean, and $13 \%$ in the Atlantic 0cean. Approximately $4 \%$ are located in the Mediterranean Sea and in northern Asia Minor. The remaining 3\% are found in midcontinental areas; mostly associated with the African rift system (Claiborne and Gera 1974, Bullard 1962).

These facts cause Claiborne and Gera (1974) to state, "The rise of magma requires extensive faulting of the lithosphere. While there are no volcanoes without great faults, there are many faults without volcanic manifestations. Thus we can state that, in general, the probability that there will be volcanic activity in a tectonically stable area with no magmatic manifestations must be significantly lower than the probability of formation of a great fault." It must be emphasized, however, that a primary assumption implicit in this statement is that the fault system associated with magmatic activity is of sufficient size to be detected during the site survey. Figure 22 shows several major volcanoes in North and South America and Africa. It illustrates the geographic distribution of these events.

Naturally, not all magmatic activity is extrusive. Intrusive magmatic activity that could fracture low permeability layers, transport the waste closer to the surface, and/or create active hydrothermal systems could also exist. Thermal and mechanical effects of intrusive magmatic activity must be considered. The size and type of the intrusion would be the primary factor determining the potential consequences. Batholiths, sills, and dikes must be considered. The area occupied by such bodies ranges from a few square kilometers to hundreds of thousands of square kilometers. 


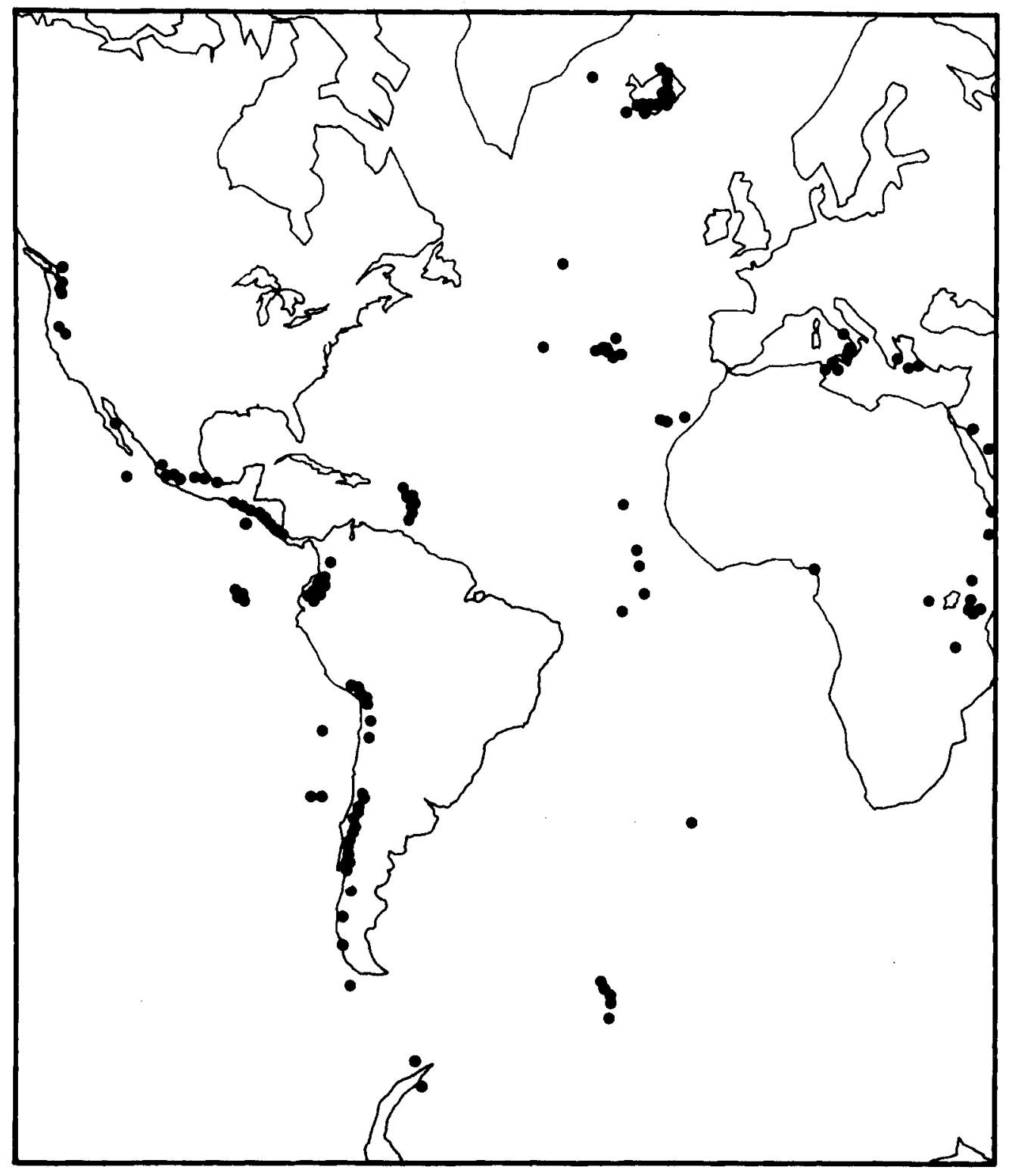

FIGURE 22. Examples of Major Volcanoes

Before discussing the potential consequences associated with magmatic activity, it should be noted that due to the lack of field data and a specific site, estimating probabilities and analyzing consequences is an extremely difficult undertaking. It may well be that magmatic emplacement rates can be shown to be slow enough that the problem can be dismissed. If not, it will be necessary to estimate probabilities and potential consequences on a sitespecific basis. 


\section{POTENTIAL CONSEQUENCES}

Assuming that some form of magmatic activity occurs in the vicinity of a waste repository, several factors will control the pathway and dispersal distance of any entrained wastes.

The composition of the magma is quite important. In general, basaltic eruptions tend to be nonexplosive and could transport radioactive material up to about $300 \mathrm{~km}$. It may be that the wastes would be entombed in the lava flow upon cooling and solidification. The Columbia River basalts are an excellent example of this magma composition. Silicic volcanic eruptions, on the other hand, are commonly highly explosive, mainly due to the high viscosity associated with greater silica content.

The exact location of the volcanic activity relative to the repository site is of primary importance. Direct intersection of the repository site by the volcanic conduit could result in immediate incorporation and transport of radioactive material. An increase in the distance from the conduit to the site causes a time lag from the onset of volcanism until incorporation and dispersal of waste material (Crowe 1979).

Assuming that the waste is contacted by magmatic material, several dispersal mechanisms are possible. Table 7 illustrates generalized transport distances of common volcanic processes associated with various types of volcanic eruptions. Dispersal mechanisms can be divided into two classes: 1) those mechan isms that are controlled by topography and are active primarily on the steep slopes of a volcano and closely adjacent areas (lava flows, volcanic mudflows, pyroclastic flows), and 2) air-fall activity that is controlled by the explosiveness of an eruption and prevailing wind directions (Crowe 1979).

A special case of magmatic activity involves an igneous body rising to an unspecified depth below the repository site. The size of such a body could vary from square meters to thousands of square kilometers. Potential consequence of such emplacement would include: broad domal uplift and radial and concentric fractures, accelerated erosion rates, faulting, juxtaposition of a hydrothemal convection system above the magma chamber, and upward propagation and eruption of surface volcanism fed from the igneous body. This could be 
TABLE 7. Transport Distances For Several Types of Magmatic Eruptions

Magma Type
Flood Basalts
Basaltic "cinder cones"
Basaltic "Phreatic"
Andesitic "composite
cone"
Silicic "Crater Lake"
Decreasing
Frequency

\begin{tabular}{rcc} 
Lava Flows & & Lahars \\
\cline { 1 - 1 } $300 \mathrm{~km}$ & -- \\
$10 \mathrm{~km}$ & $5 \mathrm{~km}$ \\
$10 \mathrm{~km}$ & $6 \mathrm{~km}$ \\
$5-10 \mathrm{~km}$ & $30 \mathrm{~km}$ \\
$5 \mathrm{~km}$ & $40 \mathrm{~km}$ \\
& Slope \\
& Control \\
& \\
Major Types
\end{tabular}

A. Strombolian

Basaltic

Andesitic

Silicic
B. Phreatomagmatic (Magma-water steam explosions)

A. Composite Volcano
B. Caldera (single center)

\section{Pyroclastic}

$\begin{array}{lll}\text { Flow } & & \text { Air Fall } \\ & & \\ --- & 30 \mathrm{~km} \\ 20 \mathrm{~km} & & \text { regional } \\ 30 \mathrm{~km} & & \text { regional } \\ 50 \mathrm{~km} & & \text { global } \\ & & \text { Wind } \\ & & \text { Control }\end{array}$

Size

Height: $100-500 \mathrm{~m}$

Width: $300-1000 \mathrm{~m}$

Disruption Depth: $200 \mathrm{~m}$

Height: $50-200 \mathrm{~m}$ Width: $0-.3-3 \mathrm{~km}$ Disruption Depth: $200 \mathrm{~m}$

Height: $0.5-3 \mathrm{~km}$ Width: $1 \mathrm{~km}-5 \mathrm{~km}$ Disruption Depth: $0.5-4 \mathrm{~km}$

Height: $0.5-3 \mathrm{~km}$ Width: $2 \mathrm{~km}-10 \mathrm{~km}$ Disruption Depth: $0.5-5 \mathrm{~km}$
Height: $0.5-2 \mathrm{~km}$ Width: $1 \mathrm{~km}-10 \mathrm{~km}$ Disruption Depth: $0.5-4 \mathrm{~km}$
B. Large Cauldrons
A. Dome Complex
Height: $1-3 \mathrm{~km}$ Width: $5-30 \mathrm{~km}$ Disruption Depth: $1-10 \mathrm{~km}$ 
manifested as magma or as a geyser of steam. Parameters controlling the magnitude of these potential events include: depth of the igneous mass, dimensions and volume of the body, and residence time as a molten body (a function of initial cooling mechanisms and heat replenishment mechanisms.)

In addition to volcanism occurring at or immediately adjacent to the repository, volcanic activity well away from the repository site can occur. There is a much higher probability of this. Effects decrease rapidly with increasing distance from the site. At distances greater than $50 \mathrm{~km}$, effects of many types of volcanic activity would be minimal. Major silicic volcanic eruptions would have the following possible consequences: surficial mantling by pyroclastic material; vegetation, drainage, and erosional modifications; and climatic alteration (Crowe 1979). Major basaltic flows could result in a surficial magma load and potentially some diagenesis or physical alterations of sedimentary material in the vicinity of the repository. Shale and sandstone might be particularly sensitive to such burial and the associated increased pressures and temperatures.

Any probability estimates concerning magmatic activity will have large uncertainties, but it may be possible to bound the estimated phenomena rates. Geological or geophysical surveys may indicate that volcanic activity is not particularly relevant to most sites.

\section{EXAMPLES OF PAST STUDIES}

\section{$\underline{\text { Logan } 1978}$}

Logan, in a report on southeastern New Mexico, addressed the question of volcanogenic transport. He lumped magma transport, volatile transport, and hydrothermal transport into one single phenomenon category and proceeded to calculate expected frequency rates for the Delaware Basin. The probability of a volcanic disturbance affecting a repository was then computed, based on a ratio of repository surface area to basin surface area.

It was assumed that there had been one volcanic event in the last $2.00 \mathrm{x}$ $10^{8} \mathrm{yr}$ and that the frequency in the future would not deviate from this pattern. Thus, a $5 \times 10^{-9} / \mathrm{yr}$ rate was established. Geometrical manipulations 
based on a $50 \mathrm{~km}^{2}$ repository sensitivity area resulted in a total probability estimate of $8 \times 10^{-12} / \mathrm{yr}$. Transport to a shallower depth, without surface expulsion, was arbitrarily assigned $8 \times 10^{-11} / \mathrm{yr}$. Finally, violent volcanic events were estimated at $2 \times 10^{-12} / \mathrm{yr}$ based on the fact that violent explosions occur at a rate of 0.3 times the basic volcanogenic activities.

The report also cites work that estimates volcanism on a global scale. Midcontinental volcanism, based on this approach, was estimated to be $9 \times$ $10^{-11} / \mathrm{yr}$.

Based on geometrical arguments, Logan computed the fraction of the repository that would be affected by the volcanic activity. He assumed that half of this total would reach the biosphere. The final results indicated that $7.5 \%$ of the waste contents would be exposed by a volcano and $0.6 \%$ by an explosive eruption.

\section{Claiborne and Gera}

Claiborne and Gera (1974) did not to analyze magmatic activities in general. They correlated the probability of volcanism to the probability of large scale faulting and stated that volcanism would be significantly less probable. Furthermore, they maintain that the consequences would be less serious than those for the impact of a giant meteorite, which they described in detail. Bertozzi et al.

In a more recent study in West Germany (Bertozzi et al. 1978), magmatic activity was categorized as: 1) extrusive activity directly capable of exhuming the wastes, 2) intrusive activity that fractures impermeable layers bounding the bedded salt layer, and 3 ) intrusive activity causing partial uplift of the wastes. The probability of extrusive magmatic activity exhuming the waste is directly related to the probability of a great fault.

This faulting probability was reduced by a factor based on the probability of magma rising through the fault, should faulting occur. No explanation was given concerning how the magnitude of this factor was derived. Table 8 presents the results of this study. Note that all numbers reflect an integrated probability. For example, there is a $2 \times 10^{-7}$ change during the $10^{6}$-yr time period. 
TABLE 8. Probability of Volcanism (Bertozzi et al. 1978)

\begin{tabular}{|c|c|c|c|}
\hline & \multicolumn{3}{|c|}{ Years } \\
\hline & $\overline{10^{4}}$ & $10^{5}$ & $10^{6}$ \\
\hline Large Faulting & 0 & $4 \times 10^{-6}$ & $4 \times 10^{-5}$ \\
\hline Magma through fault & 0 & $1 \times 10^{-3}$ & $5 \times 10^{-3}$ \\
\hline Total & 0 & $4 \times 10^{-9}$ & $2 \times 10^{-7}$ \\
\hline
\end{tabular}

Intrusive magmatic activity capable of fracturing impermeable layers was given serious consideration. Both the possible thermal and mechanical effects were discussed. Example consequences include temperature rise in a thermometamorphic belt surrounding laccoliths, shrinking of clays and associated changes in layer permeability, enhanced plasticity and flow in the salt, and high water-vapor pressures.

The lack of site specific data makes estimating probability values extremely difficult. It is assumed that no intrusive activity takes place at the time of waste disposal and that significant fracture systems are required. Significant fractures could be induced only by deep tectonic stresses. it is then assumed that a time span of at least $10^{4} \mathrm{yr}$ is required to build up stresses of the required magnitude. For longer periods, for lack of a better argument, the probabilities are related to large faulting. Therefore, the results in Table 9 are closely related to Table 8 .

TABLE 9. Probability of Igneous Intrusion Fracturing Impermeable Layers (Bertozzi et al. 1978)

\begin{tabular}{ccccc}
\cline { 3 - 4 } & $\frac{5}{10^{3}}$ & $\frac{10^{4}}{3}$ & $\frac{10^{5}}{10^{6}}$ & $\frac{10^{-9}}{5 \times 10^{-7}}$
\end{tabular}

These probability values also apply to an intrusive body that contacts the wastes, transports the nuclide inventory to a shallower depth and then cools and solidifies. All of the aforementioned thermal and mechanical effects would have to be considered for this scenario. It must be emphasized, however, that 
there is very little reason to attempt to identify occurrence probability differences between all extrusive and intrusive phenomena, since the relative height difference of a few hundred meters is rather insignificant.

Current Study at Pacific Northwest Laboratory

The PNL study on magmatic activity is being conducted by Bruce Crowe of Los Alamos Scientific Laboratories. It should be emphasized, however, that emphasis is on the emplacement rates and dispersal mechanisms associated with magmatic phenomena. The occurrence probability numbers appear so small that signficant refinement of probabilities does not seem warranted until a specific site is selected.

SUMMARY

- Only $3 \%$ of the currently active volcanoes are in midcontinental areas, with the majority of these being associated with the East African Rift.

- Magmatic activity at a reasonable depth below the repository is assumed nonexistent at the time of waste emplacement, since the associated features would be detectable.

- Intrusive as well as extrusive activity must be considered. The consequences may be different, but it is assumed that the probability of occurrence is basically the same.

- Extrusive activity can be nonexplosive (flood basalts) or explosive (silicic volcanoes). Dispersal can be via lava flows, mud flows, pyroclastic flows, and air-fall.

- Igneous activity can result in broad domal uplift and development of radial and concentric fractures, faulting, accelerated erosion rates, development of a hydrothermal convention system, and geyser actvity.

- Volcanic activity within a $50 \mathrm{~km}$ radius of the repository but not directly intersecting the wastes might result in: surficial loading, drainage and erosional changes, climatic changes, and diagenesis with potential changes in permeability of sedimentary layers. 
- Past studies have resulted in probability numbers for magmatic activity ranging from 0.0 in the first $10^{4} \mathrm{yr}$ to $10^{-7}$ in $10^{6} \mathrm{yr}$.

- The PNL study is emphasizing emplacement rates and dispersal mechanisms since the probability values appear to be sufficiently small for most sites that additional order-of-magnitude refinement is not warranted. 


\section{GEOMORPHOLOGY}

\section{INTRODUCTION}

For this report, geomorphology includes changes in the land surface due to large-scale slope failure, denudation, stream erosion, glacial erosion, coastal erosion, and general sedimentation. The following discusses both causes and effects associated with these geomorphological phenomena.

Concerning slope failure, the following topics are considered:

- slopes existing at the time of repository closure

- initiation of new slopes sufficiently steep or unstable to cause failure

- maintenance of the slope against erosion

- geologic and hydrological features favorable to failure of the slope

- consequences of slope failure, e.g., material removal or deposition, energy release, and fracturing

- the range of occurrence probabilities.

Topics covered under the category of denudation and stream erosion include:

- distribution of observed rates

- consequences of material type and man's activities

- effects of climate and topography

- epeirogenic uplift

- removal of an impermeable layer

- reduction in transport pathlengths

Glacial erosion is discussed under the headings:

- ice-scouring rates

- melt-water stream and major flood erosion

- probability of glaciation 
- deep groundwater recharge

- fracturing.

With respect to coastal erosion, the following topics are considered:

- ocean-level fluctuations (amplitudes, rates and frequencies)

- effects of erosion, sedimentation, and hydraulic gradients.

Slope Failure

A major consideration with regard to slope failure is the creation and/or maintenance of a substantial hillside slope. Obviously, in areas of gentle or flat topography, slope failure is of less consequence than in steep topography. It is assumed that a repository will be placed in an area with gentle topography, therefore processes such as faulting that could create a steep slope (e.g., fault scarp) are of primary interest.

Some mechanisms that could result in the creation of a slope include regional epeirogenic movements (magmatic activity, erosion, sediment deposition, or isostasy), and orogenic diastrophism (faulting, diapirism) (Bertozzi et a1. 1978).

Conditions other than slope initiation may be required to cause slope failure. The uplift must be rapid enough to preclude stream erosion from negating the slope formation. Sufficient water saturation or head, jointing, low shear-strength, layer anisotropy and favorable dip must also be considered.

Epeirogenic movements would probably not result in sufficiently steep slopes. Therefore the probability of slope failure should be correlated directly with large scale faulting or diapirism. Estimates from the probabilities of slumping in Western Germany are presented in Table 10.

It should be noted that in arid and semiarid climates, slope retreat may be of particular significance. Cliffs at the edges of mesas commonly retreat at rapid rates while losing little elevation. Melton (1965) reports slope retreat rates of 60 to $210 \mathrm{~m} / 10^{6} \mathrm{yr}$. If a repository were located in such a region for the purposes of siting above the water table, new probability numbers would have to be considered. 
TABLE 10. Slumping or Large Scale Mass Wasting Probabilities (Bertozzi et al. 1978)

\begin{tabular}{|c|c|c|c|c|}
\hline & \multicolumn{4}{|c|}{ Time, $\mathrm{Yr}$} \\
\hline & $10^{3}$ & $10^{4}$ & $10^{5}$ & $10^{6}$ \\
\hline $\begin{array}{l}\text { Probability of an event } \\
\text { causing } 500 \mathrm{~m} \text { accumulating } \\
\text { vertical displacement }\end{array}$ & 0 & 0 & $1 \times 10^{-6}$ & $3 \times 10-5$ \\
\hline $\begin{array}{l}\text { Maintainance of the slope } \\
\text { against erosion }\end{array}$ & - & - & $1 \times 100$ & $3 \times 10^{-1}$ \\
\hline Geologic suitability(a) & - & - & $1 \times 10^{-2}$ & $1 \times 10^{-2}$ \\
\hline $\begin{array}{l}\text { Overall probability of } \\
\text { removing } 500 \mathrm{~m} \text { of over- } \\
\text { burden by the slumping } \\
\text { process }\end{array}$ & 0 & 0 & $1 \times 10^{-8}$ & $1 \times 10^{-7}$ \\
\hline $\begin{array}{l}\text { Overall probability of } \\
\text { removing } 250 \mathrm{~m} \text { of over- } \\
\text { burden by the slumping } \\
\text { process }\end{array}$ & 0 & 0 & $1 \times 10^{-7}$ & $1 \times 10^{-6}$ \\
\hline
\end{tabular}

(a) layer anisotropy, favorable dip, significant liquid saturation

Cover removal is one obvious consequence of slope failure. Thus if the repository became part of a growing anticline or uplifted fault block, slope failure could conceivably reduce the size of the buffer zone. Major landslides are most likely to occur during and immediately following a glacial interval, and their probability for the Columbia Plateau under those conditions is estimated at $10^{-5} / \mathrm{yr}$ (Tubbs 1979).

The third general consequence attributable to slope failure is surficial fissuring. The motion down grade of large slab-like blocks can result in escarpments and shallow fissures that in some cases resemble the surface expression of faults. These fissures might increase the effective recharge to the unconfined groundwater system, but should not be a signficant threat to a deeply buried repository.

In conclusion, it appears that slope failure is not a particularly serious issue for a repository located in an area of low relief and low tectonic activity. 


\section{General Denudation}

Denudation refers to a general broad-based lowering of the land surface due to erosion and must be distinguished from stream or glacial downcutting. It appears highly unlikely that denudation could cause exhumation of a repository; however, removal of tens of meters of cover is possible. This could change the transport pathlength for nuclide migration and/or result in the removal of a relatively impermeable layer. Subsequent vertical groundwater recharge or enhanced stream erosion might result.

A general denudation rate for the Pasco Basin in the Columbia Plateau region has been estimated at $50 \mathrm{~m} / 10^{6} \mathrm{yr}$ under present conditions. This could be increased approximately 50\% under more adverse climatic conditions (Scott 1979). In the West German study, a rate of $100 \mathrm{~m} / 10^{6} \mathrm{yr}$ is proposed (Bertozzi et al. 1978). The possibility of exceptionally high denudation rates (hundreds of meters per million years) cannot be excluded a priori; however, such rates appear to be highly unlikely. Table 11 summarizes the West German conclusions.

The rate of denudation is site dependent. It depends, for example, on climate, topography, material lithology, and to a major extent on human activity. Erosion rates can be increased by as much as one order of magnitude by injudicious farming practices (Judson 1968). Tables 12 and 13 list long-term denudation rates for several geographical regions and Table 14 illustrates the influence of relief and climate on denudation. Naturally, areas of recent orogenesis (mountain building) have the greatest relief and the highest denudation rates.

TABLE 11. Probabilities of Massive Denudation

(Bertozzi et al. 1978)

\begin{tabular}{lcccc}
\cline { 3 - 4 } & $\frac{3}{10^{4}}$ & $\frac{10^{5}}{10^{-8}}$ & $\frac{10^{6}}{10^{-7}}$ \\
Probability of $500 \mathrm{~m}$ denudation & 0 & $10^{-8}$ & $10^{-6}$ \\
Probability of $250 \mathrm{~m}$ denudation & 0 & $10^{-8}$ & $10^{-6}$
\end{tabular}


TABLE 12. Past and Present Rates of Denudation (from Menard 1961)

(Gera and Jacobs 1972)

Area Volume Ratio of

Denuded, Time, (a) Deposits, Denudation, Past Rate, Present Rate, Past and $10^{6} \mathrm{~km}^{2} \quad 10^{6} \mathrm{yr} \quad 10^{6} \mathrm{~km}^{3} \quad \mathrm{~km}, \mathrm{~cm} / 1000 \mathrm{yr} \mathrm{cm} / 1000 \mathrm{yr}$ $\underline{100 \mathrm{~km}^{2}} 10^{6} \mathrm{yr}-1 \mathrm{~km}^{3}$

Region

Appalachian

1.0

125

7.8

7.8

6.2

6.9

11.1

8.5

8.5

0.6

0.7

2.2

4.8

4.6

21

3

$$
\underset{(L . \text { Cret.) }}{(c)}
$$

Rocky Mountajn 0.4
$(U$. Cret.)
$c)$
40 $1.1(d)$

$4.6(\mathrm{e})$

Present Rate

5.6

1.0

$100(f)$

0.2

\footnotetext{
(a) Geological Names Committee, 1958, U.S. Geological Survey

(b) Area denuded in past

(c) Gilluly (1949)

(d) Suspended load of rivers $+33 \%$ (33\% added by Leopold et al., 1964)

(e) Suspended load of rivers $+10 \%$ ( $10 \%$ added by Leopold et a1., 1964)

(f) Suspended load of rivers
} 
TABLE 13. Rates of Regional Erosion in the United States (Modified from Judson and Ritter 1964) (Gera and Jacobs 1972) 
TABLE 14. Relative Rates of Denudation in Uplands and Lowlands in Different Climates (Modified from Corbel 1959) (Gera and Jacobs 1972)

Physiographic Environment

$$
\text { Lowlands: } \text { slope }=0.001
$$

Periglacial climate, permafrost

Climate with snow accumulation in winter

Temperature oceanic climate (Lower Rhine, Seine, Lower Loire)

Continental climate (Missouri-Mississippi)

Hot-dry climate (Mediterranean-New Mexico)

Tropical desert climate (Central Sahara)

Hot-moist climate with dry season

Hot-mo ist climate, equatorial

Mountains: slope $=0.01$

Periglacial climate (Glamaa, Bovra, Mt. Drac, Arve)

Extreme nival climate (Southeastern Alaska)

Oceanic climate, intermediate elevation

Mediterranean $\mathrm{cl}$ imate, high elevation

(Durance, Gran Sasso)

Mediterranean climate, semi-dry (Isonzo, Brenta)

Hot-dry climate (Southwestern United States) (Tunisia)

Hot-moist climate (Usumacinta)
Estimated Rate of Denudation, $\mathrm{cm} / 1000 \mathrm{yr}$

1.5

2.9

2.7

5.8

1.2

$0.1(?)$

3.2

2.2

60

80

22

45

10

18

9.2

Schumm (1963) obtained the curve shown in Figure 23 by plotting the denudation rates for drainage areas of about $500 \mathrm{~km}^{2}$ versus the relative relief of the basin (relief of basin divided by basin length). An extrapolation from a drainage basin of one size to a basin of differing size may be done using a relationship prposed by Brune (1948). According to this relation, rates of denudation are inversely proportional to the 0.15 power of the drainage area. Because the basin length is constant, the figure also shows the increase in denudation rates as the relief of the basin is increased to as much as $9000 \mathrm{~m}$ (Schumm 1963, Brune 1948, Gera and Jacobs 1972). 


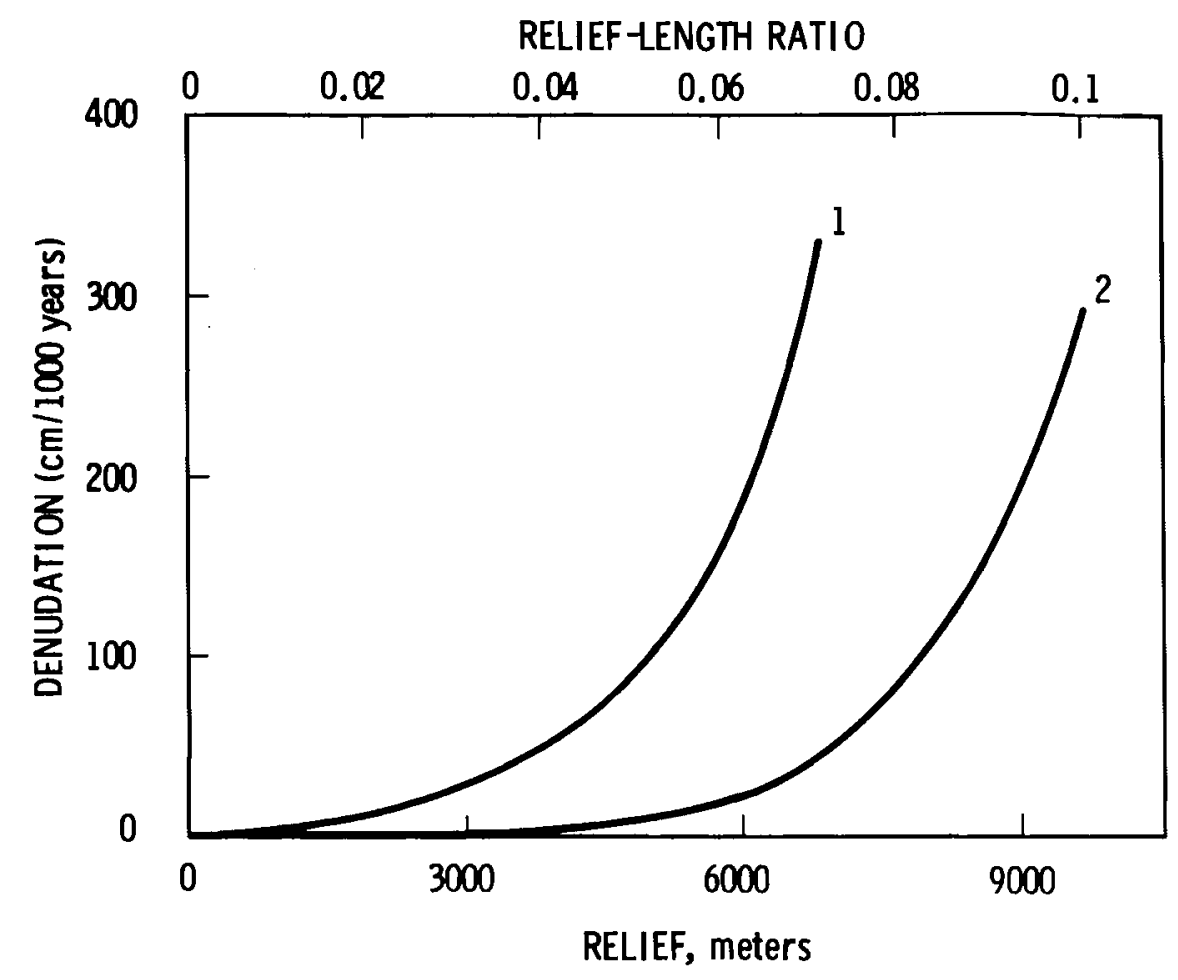

FIGURE 23. Relation of Denudation Rates to Relief-Length Ratio and Drainage Basin Relief

\section{Stream Erosion}

Average denudation rates do not reflect the much greater rates possible for local stream erosion. Gera and Jacobs (1972) used the Grand Canyon to illustrate this point. They concluded that the Grand Canyon, $350 \mathrm{~km}$ long and $1600 \mathrm{~m}$ maximum depth, was formed in 1.5 to 2 million years during which time the general region was being uplifted to a height of 1800 to $2400 \mathrm{~m}$ above sea level. These estimates result in a stream erosion rate of $800 \mathrm{~m} / 10^{6} \mathrm{yr}$, which is five times as high as the regional denudation rate $\left(160 \mathrm{~m} / 10^{6} \mathrm{yr}\right)$. This is not an isolated case. Many valleys show evidence of changes in flood level in Quaternary times of tens to hundreds of meters (Fournier 1960; Goldberg and Griffin 1964; and Holeman 1968). It has been estimated that the maximum stream erosion rate possible in the Pasco Basin near Hanford is approximately $350 \mathrm{~m} / 10^{6} \mathrm{yr}$ assuming a commensurate rate of anticlinal uplift in the area. Without such uplift, the rate should be only $50 \mathrm{~m} / 10^{6} \mathrm{yr}$ (Tubbs 1979). 
Denudation rates in Figure 23 are adjusted to drainage areas of about $4000 \mathrm{~km}^{2}$. Curve 1 is based on the average maximum denudation rate of $91.5 \mathrm{~cm} / 1000 \mathrm{yr}$ when relief-length ratio is 0.05 . Curve 2 is based on actual data from small drainage basins in areas underlain by sandstone and shale in semi-arid regions of the Western United States (Modified from Schumm 1963) (Gera and Jacobs 1972).

The consequences associated with denudation or stream erosion are not limited to a reduction of transport pathlength (overburden thickness). It is quite possible that removal of an impermeable layer would permit local vertical recharge and new groundwater circulation patterns. Therefore, it is important to select a site where excessive erosion in the future is unilikely. As a guide, it appears that uplifting of an area has an effect an order of magnitude greater on erosion rates than does changing the local climate (Gera and Jacobs 1972).

Glacial Erosion

In this discussion, glacial erosion refers to ice scouring, local meltwater stream erosion, and massive flood erosion of the Missoula type. The literature on the subject of ice erosion can be summarized in one statement: Erosion rates are temporally and spatially extremely variable, and the cause of this is not totally understood. White (1972), suggests that hundreds of meters of erosion occurred on the Canadian Shield due to late Quaternary ice sheets, while other investigators contend that erosion of only tens of meters is indicated, with an average of possibly three meters per glacial cycle (Sugden 1976, Mathews 1975). The periphery of an ice sheet is normally a depositional environment, however melt-water streams can in some cases result in deep linear erosion (Sugden 1976 and 1977). The Finger Lakes, for example, appear to have this origin. The erosion of the basins of the Great Lakes is probably also due to ice sheet action, possibly associated with fracturing of the crust under the ice sheet load (Brotchie and Silvester 1969, Bul1 1979).

Ice sheets have advanced and retreated several times in the last $10^{6} \mathrm{yr}$. It is intriguing to note that "relic" Great Lakes (those cut during the earlier glacial episodes and subsequently filled by later episodes) are not observed. This leads one to conclude that the same basins are eroded time and time again. 
Consequently, Bull states; "In future glaciations of North America, deep erosion by ice action will occur only in those areas where deep erosion has already occurred".

Some additional estimates of glacial erosion can be found. From the quantity of sediments carried to the deep Atlantic by ice-rafting and other mechanisms, an average of $16 \mathrm{~m}$ of continental material must have been eroded in the last $3 \times 10^{6} \mathrm{yr}$ (Ruddiman 1977). This is likely to be a minimum erosion rate because the computations ignore the erosion products in solution and fine suspension (Bu11 1979).

The rate of glacial erosion is controlled by several factors: 1) rate of glacier movement, 2) thickness of the ice, 3) physical characteristics of the base of the glacier, 4) erodibility of the geological material beneath the glacier, and 5) topography (Gera and Jacobs 1972).

Table 15 presents examples of present rates of glacial erosion (Corbel 1959). According to Corbel, present glacial erosion is, on the average, four times more effective than fluvial erosion. If only maximum observed rates are considered, then $\mathrm{glacial}$ erosion is 25 times as effective as flood erosion.

Gera and Jacobs (1972) conclude that glacial erosion differs considerably from stream erosion and therefore deserves careful consideration, not only because of the very high rates that it can attain, but also for its capacity to extend the erosive action many hundreds of meters below sea level.

According to Tubbs massive floods can, in some geographic areas, be associated with glacial episodes. A classical example is the series of Missoulatype or scabland floods that have occurred in eastern Washington State.

- . recurrence of scabland floods or Columbia Valley glacial outburst floods as described in the literature will almost certainly inundate the Pasco Basin again. Such flooding did not occur only at the end of the glacial episodes, but also occurred as a result of ice-front fluctuations during glaciation. The probability of such a flood occurring during any 100-yr period within or immediately following a glacial interval appears to be approximately 0.01 . Although various such floods have probably 
TABLE 15. Present Rates of Glacial Erosion (Data from Corbel 1959, Gera and Jacobs 1972)

\begin{tabular}{|c|c|c|c|}
\hline $\begin{array}{l}\text { Name of } \\
\text { Torrent }\end{array}$ & $\begin{array}{l}\text { Name of } \\
\text { Glacier }\end{array}$ & $\begin{array}{c}\text { Geographical } \\
\text { Location }\end{array}$ & $\begin{array}{l}\text { Denudation, } \\
\mathrm{cm} / 1000 \mathrm{yr}\end{array}$ \\
\hline France & & Valais, France & 100 \\
\hline Bossons & & Chamonix, France & 180 \\
\hline Nant Blanc & Etendard & French Alps & 160 \\
\hline Heilstruga & & Norway & 140 \\
\hline Memurelven & & Norway & 160 \\
\hline Auserfjotur & & Icel and & 220 \\
\hline Jokul1sa & & Icel and & 220 \\
\hline Hoffelsjokul1 & & Icel and & 320 \\
\hline Hofsjoku 11 & & Iceland & 180 \\
\hline Isortok & & Western Green 1 and & 250 \\
\hline \multirow[t]{3}{*}{ Saskatchewan } & & Canada & 200 \\
\hline & $\operatorname{Muir}(a)$ & Alaska & 500 \\
\hline & Hidden (b) & Alaska & 3000 \\
\hline
\end{tabular}

(a) The rate of erosion mentioned by others for this glacier is four times higher

(b) This extremely high rate of erosion is related to a period of very rapid advance at the beginning of this century. The front of Hidden glacier advanced about $3 \mathrm{~km}$ at the rate of 10 to $15 \mathrm{~m} /$ day. During this period, the glacier produced $30,000,000 \mathrm{~m}^{3}$ of sediments. This short-term phenomenon is normally called a surge.

been impounded to various depths, a lake elevation of $350 \mathrm{~m}$ is generally accepted. This represents a volume of 175 cubic miles of water within the Pasco Basin alone. Estimates of the persistence of such a lake range from two days to two weeks, with one week probably being the most reasonable figure... (Tubbs 1979).

Tubbs concludes that seven to nine such flooding episodes might occur in the Pasco Basin in the next million years and that the transient impoundment of such a large quantity of water might significantly affect groundwater recharge and water table elevations. 


\section{Glacial Frequency}

Since the geomorphology of an area may be significantly affected by glaciation and associated flooding, some consideration of the occurrence frequency to be anticipated is warranted. It must be emphasized that no single theory of climatological, glacial, and ocean-level interaction is accepted by the earth science community. However most authors believe that, barring man's intervention, a new glacial episode is likely in the next 10,000 to 20,000 yr and may begin as soon as 4,000 $\mathrm{yr}$ from now (Bull 1979). Fortunately, there is an inherent time delay between the onset of glaciation and any impact on repository sites in the northern United States.

A computation of the probability of a given site being glaciated depends in part on: 1) the occurrence of North American continental glaciation, 2) the site latitude, and 3) the local topography. Thus, the probability for a site in New Mexico may nearly be zero, whereas the probability of at least one such glaciation at Columbus, Ohio in the next $10^{6} \mathrm{yr}$ is close to 1.0 (Bu11 1979). The chance of continental ice covering Columbus in the next 4,000 to 10,000 yr, assuming no significant interference by man, is 0.25 to 0.50 (Bu11 1979). .

In the West German study (Bertozzi et al. 1978), the probability that an appropriately chosen site in Germany will be glaciated in the next $10^{6} \mathrm{yr}$ is given as 0.01 . The probability that such a site will be eroded to a depth of 250 to $500 \mathrm{~m}$ in $10^{6} \mathrm{yr}$ is then given as $5 \times 10^{-4}$, the total resulting probability being $5 \times 10^{-6}$. This was estimated based on the ratio of total surface area of ancient glacial lakes to the total surface area extent of Pleistocene glaciation in West Germany.

\section{Coastal Geomorphology}

In this report, coastal geomorphology refers primarily to the effects of a fluctuating ocean level. This section is devoted to a brief discussion of how the ocean level may change over the next $10^{6} \mathrm{yr}$, and how the change might affect erosion rates, sedimentation, and hydraulic gradients within 150 to $300 \mathrm{~km}$ of the coast. 
Numerous variables influence sea level fluctuations. These include: 1) the galactic cycle which is on the order of 200 to $250 \mathrm{M} \mathrm{yr}, 2$ ) paleogeography or continental migration, 3) earth orbital physics with a $41,000 \mathrm{yr}$ cycle of axial tilt, a 21,000-yr cycle of precession, and a 95,000-yr cycle of orbital eccentricity, all of which may superpose into a master 100,000-yr cycle, and 4) the solar cycle with its variable sun spot density (Schwartz 1979).

All of these factors tend to manifest themselves by changing the state of world "eustasy." Eustasy is subdivided into glacio-eustasy which is a change in the quantity of water, and tectono-eustasy which is a change in the shape of the container or basin (Schwartz 1979). Table 16 shows the amount of change, total range, and rate of both glacio- and tectono-eustatic changes of sea level for a period of one million years.

At present, the sea level is rising at 3 to $4 \mathrm{~mm} / \mathrm{yr}$ ( 1 to $2 \mathrm{~mm} / \mathrm{yr}$ glacioeustatic and $2 \mathrm{~mm} / \mathrm{yr}$ subsidence). It is estimated that a short-term maximum rate of ocean level increase would be 2 to $4 \mathrm{~cm} / \mathrm{yr}$. Similarly, a fall in sea level would be at rates of 3 to $4 \mathrm{~mm} / \mathrm{yr}$ to $4 \mathrm{~cm} / \mathrm{yr}$ (Schwartz 1979).

Coastal erosion rates vary from less than $0.01 \mathrm{~cm} / \mathrm{yr}$ in hard rocks to a typical $1 \mathrm{~m} / \mathrm{yr}$ in soft sediments, to $1 \mathrm{~m} /$ day in mud lumps or new volcanic material. Typically, however, the result of coastal erosion is leveling along a sloping coastal plane (Schwartz 1979). The total magnitude and direction of erosion is a combination of vertical and horizontal components.

Sediment accumulation rates can be up to $0.20 \mathrm{~m} / \mathrm{yr}$ during periods of uplift. To simulate such erosion and deposition, it is necessary to consider

TABLE 16. Changes in Sea Leve1 (Courtesy of M. L. Schwartz, Western Washington University)

\begin{tabular}{|c|c|c|c|}
\hline Type & Amount & Range & Rate \\
\hline glacio-eustatic & $+100 \mathrm{~m}$ & $200 \mathrm{~m}$ & fast $\left(10^{5} \mathrm{yr}\right)$ \\
\hline tectono-eustatic & $+250 \mathrm{~m}$ & $500 \mathrm{~m}$ & slow $\left(10^{6} \mathrm{yr}\right)$ \\
\hline possible combination & $\pm 350 \mathrm{~m}$ & $700 \mathrm{~m}$ & \\
\hline
\end{tabular}


the following scenarios: 1) steady state, 2) available extra sediment, 3) a scarcity of sediment, and/or 4) variations in the wave and tidal regime (Schwartz 1979).

Sea level fluctuation can affect subsurface hydraulic gradients as well as surface gradients. In general, ocean-level increases will decrease hydraulic gradients and ocean-level decreases will increase gradients, especially if the coastal region is flat. In the Gulf Interior salt dome region hydraulic gradient in the regional aquifers would be increased about $30 \%$ for a $100 \mathrm{~m}$ drop in ocean level (Davis 1979).

Coastal erosion and sedimentation are not particularly significant to a repository buried at a depth of $600 \mathrm{~m}$ or more. However, perturbation to subsurface hydraulic gradients due to a lowering of the base level should be considered. In addition, ocean inundation should be considered to be a possibility for any coastal site where the land surface is less than 100 to $200 \mathrm{~m}$ above present sea level. Such inundations would cause a decrease in lateral hydraulic gradients and an increase in vertical recharge on water table elevations.

It has been suggested that ocean inundation might lead to sedimentation, and that if a sufficient thickness of sediments were to accumulate and some form of differential compaction or loading were to occur, renewed salt-dome growth (diapirism) might result. Diapirism might fracture caprocks and cause salt dissolution. This upward motion of the dome appears to be continuing in areas close to the Gulf of Mexico but has apparently ceased in the inland dome regions (Kehle 1979). There is some disagreement about the potential for renewed uplift. In general, however, most researchers agree that the process leading to renewed diapirism requires hundreds of thousands or millions of years.

Kehle considers the potential for renewed growth of inland domes to be negligible. He suggests that dome growth is a single cycle, self-perpetuating process and that seismic and borehole analyses can reveal where on the growth curve any given dome may currently reside. 
Summary

- This section briefly discusses: 1) slope failure, 2) denudation, 3) stream erosion, 4) glacial erosion, 5) coastal erosion, and 6) sedimentation.

- Slope failure is most likely to occur on a steep slope and can be enhanced by increased water saturation or head, jointing, low shear strength, layer anisotropy, and favorable dip.

- Slope failure might cause a reduction of overburden thickness, and/or surficial fissuring.

- It appears that slumping is not a particularly serious issue for an area with low relief and low tectonic activity. Furthermore, epeirogenic uplift should not initiate slumping activity.

- Examples of denudation rates include: 1) $100 \mathrm{~m} / 10^{6} \mathrm{yr}$ for West Germany, 2) 50 to $75 \mathrm{~m} / 10^{6} \mathrm{yr}$ for the Pasco Basin, and 3) $160 \mathrm{~m} / 10^{6} \mathrm{yr}$ for the Grand Canyon area.

- The rate of denudation depends on climate, topography, material lithology, and human activity.

- Examples of stream erosion rates include: 1) $50 \mathrm{~m} / 10^{6} \mathrm{yr}$ for the Pasco Basin without anticlinal uplift, 2) $350 \mathrm{~m} / 10^{6} \mathrm{yr}$ for the Pasco Basin with uplift, and 3) $800 \mathrm{~m} / 10^{6} \mathrm{yr}$ for the Grand Canyon.

- The potential consequences associated with denudation and stream erosion include: a reduction of overburden thickness, the removal of a relatively impermeable layer, and enhanced vertical groundwater recharge.

- It appears that uplifting an area has an order of magnitude greater impact or erosion rates than does changing the local climate.

- Glacial erosion involves ice scouring, local selective melt-water stream erosion, and massive flood erosion of the Missoula type.

- Ice erosion rates are temporally and spatially variable. The magnitudes of such erosion may vary from a few meters per million years to hundreds of meters per million years. 
- Future deep erosion by ice action will probably occur only in those areas where deep erosion has already occurred.

- Based on present glacial activity, ice erosion is, on the average, four times more effective than fluvial erosion.

- The probability of massive flooding in the Pasco Basin during and immediately following a glacial eposide is $10^{-4} / \mathrm{yr}$ and the consequence would be an impounded lake in the Pasco Basin and transient vertical groundwater recharge.

- The potential consequences associated with glaciation include:

1) removal of overburden and potentially a low permeability confining layer, 2) flooding and short-term impoundment of water in lowland areas, 3) fracturing near the margin of the ice sheet, and 4) deep groundwater recharge near the margin of the ice sheet.

- Sea level may vary by as much as $+100 \mathrm{~m}$ over a $10^{5}-y$ r period due to glacial activity; and by $\pm 250 \mathrm{~m}$ over $10^{6}$ years due to tectonic activity.

- At present, the ocean is rising at 3 to $4 \mathrm{~mm} / \mathrm{yr}$. Potential rates are 3 to $4 \mathrm{~mm} / \mathrm{yr}$ to $4 \mathrm{~cm} / \mathrm{yr}$.

- Coastal erosion and sedimentation are not considered significant to a deeply $(>600 \mathrm{~m})$ buried repository.

- Sea-level fluctuations can affect hydraulic gradients in near-coastal aquifer. For example, a $100 \mathrm{~m}$ fall in ocean level might increase hydraulic gradients by $30 \%$ in the Gulf coast area. 


\section{REFERENCES}

Algermissen, S. T. 1969. "Seismic Risk Studies in the United States." In Proceedings of Fourth World Conference of Earthquake Engineers. Asociacion Chilena de Sismolosia e Ingeneria Antisismica, Santiago, Chile V1. 19-27.

Algermissen, S. T., and D. M. Perkins. 1972. "A Technique for Seismic ZoningGeneral Considerations and Parameters." In Proceedings of International Conference of Microzonation. 2:868-878. Seattle, Washington.

Anderson, J. G. 1978. "Estimating the Seismicity from Geologic Structure for Seismic Risk Studies." Bull. Seis. Soc. Am.

Bertozzi, G., M. D'Alessandro, F. Girardi, and M. Vanossi. 1978. Safety Assessment of Radioactive Waste Disposal Into Geological Formations: A Preliminary Application of Fault Tree Analys is to Salt Deposits. Comm ission of the European Communities Joint Research Centre, Ispra Establishment Chemistry Division. Ispra, Italy.

Biot, M. A. 1965. Mechanics of Incremental Deformation. John Wiley and Sons, Inc., New York.

Bond, F. W. 1978. Basalt Waste Isolation Report RHO-BWI-78-100. Rockwe 11 Hanf ord, Richl and, Washington.

Borg, I. Y. et al. 1976. Review and analysis of existing information. Part 1 of Information Pertinent to the Migration of Radionuclides in Ground Water at the Nevada Test Site. Report UCRL-52078. Lawrence Livermore Laboratory, Livermore, California.

Bredehoeft, J. D., A. W. England, D. B. Stewart, N. J. Trask, and I. J. Winogard. 1978. "Geologic Disposal of High Level Radioactive Wastes-Earth Science Perspectives." U.S. Geological Survey Circular. 799:15.

Brotchie, J. F. and R. Silvester. 1969. "On Crustal Flexure." Journal of Geophysical Research. 74:5240-5252.

Brown, R. E. 1968. A Study of Reported Faulting in the Pasco Basin." BNWL-662, Pacific Northwest Laboratory, Richland, Washington.

Bruce, W. F. 1978. "Fluid Permeability in Rock-Theory and Observation." Paper presented at the Symposium on Current Developments in Rock Engineering, Massachusetts Institute of Technology, Cambridge, Massachusetts.

Brune, G. 1948. "Rates of Sediment Production in Midwestern United States." TP-65:40. Soil Conservation Service. 
Budyko, M. I. 1968. "On the Causes of Climate Variations." Sveriges Met. Hydrog. Inst. Medd. 28(B)6-13.

Burkholder, H. C., J. A. Stott lemyre, and J. R. Raymond. 1977. "Safety Assessment and Geosphere Transport Methodology for the Geologic Isolation of Nuclear Waste Materials." In Proceedings of the Joint Workshop of the OECD Nuclear Energy Agency and the Commission of European Communities, pp. 216-229. Ispra, ItaTy.

Bull, Colin. 1979. "Glaciological Parameters of Disruptive Event Analysis." In A Summary of FY-1978 Consultant Input for Scenario Methodology Development, Ed. B. L. Scott. PNL-2851, Pacific Northwest Laboratory, Richland, Washington.

Bullard, F. M. 1962. Volcanoes in History, in Theory, in Eruption. University of Texas Press, Austin, Texas.

Claiborne, H. C. and F. Gera. 1974. Potential Containment Failure Mechanisms and The ir Consequences at a Radioactive Waste Repository in Bedded Salt in New Mexico. Report ORNL-TM-4639, Oak Ridge National Laboratory, Oak Ridge, Tennessee.

Coombs, H. A. 1979. "Structural Geology of the Columbia Plateau and Environs as Related to the Waste I solation Safety Assessment Program." In A Summary of FY-1978 Consultant Input for Scenario Methodology Development, ed. B. L. Scott. PNL-2851, Pacific Northwest Laboratory, Richland, Washington.

Corbel, J. 1959. "Vitesse de l'Erosion." Zeitschrift fur Geomorphologie. $3: 1-28$.

Crowe, B. M. 1979. Disruptive Event Analysis-Volcanism and Igneous Intrusion. In A Summary of $F Y-1978$ Consultant Input for Scenario Methodology Development, ed. B. L. Scott. PNL-2851, Pacific Northwest Laboratory, Richland, Washington.

Davis, S. N. 1969. "Porosity and Permeability of Natural Materials." In Flow Through Porous Media, ed. R. J. M. DeWiest. p. 53-89. Academic Press, New York.

Davis, S. N. 1979. "Hydrogeologic Effects of Natural Disruptive Events on Nuclear Repositories" In A Summary of FY-1978 Consultant Input for Scenario Methodology Development, ed. B. L. Scott. PNL-2851, Pacific Northwest Laboratory, Richland, Washington.

Fournier, F. 1960. Climat et Erosion. Presses Universitaires de France. Paris.

Gera, F. 1975. Geochemical Behavior of Long-Lived Radioactive Wastes. Oak Ridge National Laboratory, Oak Ridge, Tennessee. ORNL-TM-4481. 
Gera, F. and D. G. Jacobs. 1972. Considerations in the Long-Term Management of High-Level Radioactive Wastes. ORNL-4762, Oak Ridge National Laboratory, Oak Ridge, Tennessee.

Goldberg, E. D., and J. J. Griffin. 1964. "Sedimentation Rates and Mineralogy in the South Attantic." J. Geophys. Res. 69(20): 4293-4309.

Goldthwait, R. P. et al. 1965. "Pleistocene Deposits of the Erie Lobe" Quaternary History of the United States, ed. H. E. Wright and D. G. Frey, pp. 63-97. Princeton University Press, Princeton, New Jersey.

Gretener, P. E. 1967. "Significance of the Rare Event in Geology" American Association of Petroleum Geologists Bulletin, 51(11):2197-2206.

Hartman, W. K. 1979. "Long Term Meteorite Hazards to Buried Nuclear Wastes." In A Summary of FY-1978 Consultant Input for Scenario Methodology Development, ed. B. L. Scott. PNL-2851, Pacific Northwest Laboratory, Richland, Washington.

Hodges, C. A. 1978. "Basaltic Ring Structures of the Columbia Plateau." Geological Society of America Bulletin, 89:1281-1289.

Holeman, J. N. 1968. "The Sediment Yield of Major Rivers of the World." Water Resources Res. 4(4):737-747.

Holmes, A. 1960. "A Revised Geological Time-Scale." Edinburgh Geol. Soc. Trans. $17(13): 183-215$.

Holmes, A. and D. L. Holmes. 1964. Holmes Principles of Physical Geology. John Wiley and Sons, New York.

Houser, F. N. 1970. "A Summary of Information and Ideas Regarding Sinks and Collapse, Nevada Test Site." U.S. Geol. Survey, Open-File Report, NTS-216, USGS-474-41.

Humphreys, W. J. 1942. Way of the Weather, a Cultural Survey of Meteorology. The Ronald Press Company, New York.

Jamison, D. B., and G. W. Cook. 1978. An Analys is of the Measured Values for the State of Stress in the Earth's Crust. Technical Progress Report, LBL 7071, Lawrence Berkeley Laboratory, Berkeley, Cal ifornia.

Judson, S. 1968. "Erosion Rates Near Rome, Italy." Science, $160: 1444-1446$.

Judson, S., and D. F. Ritter. 1964. "Rates of Regional Denudation in the United States." J. Geophys. Res. 69:3395-3401.

Judson, S. 1968. "Erosion of the Land, or What's Happening to our Continents?" American Scientist. 56(4):356-374. 
Kehle, R. 1979. Identifying Suitable "Piercement" Salt Domes for Nuclear Waste Storage Sites. In A Summary of FY-1978 Consultant Input for Scenario Methodology Development, ed. B. L. Scott. PNL-2851, Pacific Northwest Laboratory, Richland, Washington.

King and Knopoff. 1968. "Stress Drop in Earthquakes." Bu11. Seismo1. Soc. Amer. N58. pp. 249-257.

Kreitler, C. W., et a1. 1977. "Hydrogeology of Gulf Coast aquifers, HoustonGalveston area, Texas." Gulf Coast Assoc. Geo1. Sci. Trans. 27:72-89.

Kuk 1a, G. K. 1979.' Probability of Expected Climate Stresses in North America in the Next One Million Years. In A Summary of FY-1978 Consultant Input for Scenario Methodology Development, ed. B. L. Scott. PNL-2851, Pacific Northwest Laboratory, Richland, Washington.

Lamb, H. H. 1970. "Volcanic Dust in the Atmosphere, with a Chresology and Assessment of its Meterological Significance." Roy. Soc. London Phil. Trans. A266:425-533.

Lindren, E. N., and J. A. Halpern. 1977. "In-Situ Stress Analysis." Presented at the 18th U.S. Symposium on Rock Mechanics.

Logan, S. E. and M. C. Berbano. 1977. "Geologic Modeling in Risk Assessment Methodology for Radioactive Waste Management." In Proceeedings of Workshop Organized jointly by the OECD Nuclear Energy Agency and the Commission of European Communities, pp. 77-115. May 23-27.

Logan, S. E. 1978. Implementation of a Technology Assessment for Radioactive Waste Management. Univ. of New Mexico.

Malone, S. D., G. H. Roth, and S. W. Smith. 1975. "Details of Microearthquake Swarms in the Columbia Basin." Washington Bu11. Seism. Soc. Am. 65:855-864.

Leopold, L. B., M. G. Wolman, and J. P. Miller. 1964. Fluvial Processes in Geomorphology. W. H. Freeman, San Francisco, Cal ifornia.

Manger, G. E. 1963. "Porosity and Bulk Density of Sedimentary Rocks." U.S. Geo1. Survey Bu11. 1144-E.

Marsily, G., E. et a1. 1977. "Nuclear Waste Disposal; Can the Geologist Guarantee Isolation?" Science. 197(4303):519-527.

Mathews, W. H. 1975. "Cenozoic Erosion and Erosion Surfaces of Eastern North America." American Journal of Science. 275:818-824.

McGinnis, L. D. 1968. "Glaciation as a Possible Cause of Mineral Deposition." Economic Geology. 63:390-400. 
McKee, B. 1972. Cascadiae. McGraw Hill, New York.

Melton, M. A. 1965. "The Geomorphic and Paleoclimatic Significance of Alluvial Deposits in Southern Arizona." Jour. Geology. 73(1):1-38.

Menard, H. W. 1961. "Some Rates of Regional Erosion." Journal Geol. $69: 154-161$.

Moberly, R. Jr. 1963. "Rates of Denudation in Hawaii." J. Geol. $71(3): 371-375$.

Mundi, E. K. and J. R. Wallace. 1973. "On the Permeability of Some Fractured Crystalline Rocks." Assoc. Engineering Geol. Bull. 10:299-312.

O'Keefe, J. D. and T. J. Ohrens. 1977. "Impact-Induced Energy Partitioning, Melting, and Vaporization on Terrestrial Planets." In Proceedings of the Lunar Science Conf. 8:33-57.

Peltier, W. R. and J. T. Andrews. 1976. "Glacial-Isostatic Adjustment-I The Forward Problem." Geophysical Journal of Royal Astronomical Society. $46: 605-646$.

Pratt, H. R., W. A. Hustrulid, and D. C. Stephenson. 1978. Earthquake Damage to Underground Facilities. Topical Report, DP-1513. Savannah River Laboratory, Aiken, South Carolina.

Rudd iman, W. F. 1977. "Late Quaternary Deposition of Ice-Rafted Sand in the Subpolar North Atlantic (1at. 40 to $65 \mathrm{~N}$ )." Bulletin of the Geological Society of America. 88:1813-1827.

Sanford, A., and T. Toppozada. 1974. "Seismicity of the Proposed Radioactive Waste Disposal Site in Southeastern New Mexico." New Mexico Bureau of Mines and Mineral Resources, Circular 143. 15 pp.

Sanyal, S. K., K. A. Kvenvolden, and S. S. Marsden. 1971. "Permeabilities of Precambrian Onverwacht Cherts and Other Low Permeability Rocks." Nature. $232(5309): 325-327$.

Schumm, S. A. 1963. "The Disparity Between Present Rates of Denudation and Orogeny." U.S. Geological Survey Professional Paper 454-H. pp. H1-H13.

Schwartz, M. L. 1978. Sea Level Characteristics for the Next One Million Years. In A Summary of FY-1978 Consultant Input for Scenario Methodology Development, ed. B. L. Scott. PNL-2851, Pac if ic Northwest Laboratory, Richland, Washington.

Scott, B. L. 1979. A Summary of FY-1978 Consultant Input for Scenario Methodology Development. PNL-2851, Pacific Northwest Laboratory, Richland, Washington. 
Slemmons, D. B. 1977. "State-of-the-Art for Assessing Earthquake Hazards in the U.S., Report 6, Faults and Earthquake Magnitude, MisC. Paper. S-73-1, U.S. Army Engineer Waterways Experiment Station. Vicksburg, Mississippi.

Stott lemyre, J. A. et al. 1979. A Conceptual Simulation Model for Release Scenario Analys is of a Hypothetical Site in Columbia Plateau Basalts. PNL-2892, Pacific Northwest Laboratory, Richland, Washington.

Shackleton, N. J. and Opdyke, N. D. 1973. "Oxygen Isotope and Poleomagnetic Stratigraphy of Equational Pacific Core V28-238: 0xygen Isotope Temperatures and Ice Volumes on a $10^{5}$ and $10^{5}$ Year Scale." Quaternary

Research. 3:39-55.

Sugden, D. E. 1976. "A Case Against Deep Erosion of Shields by Ice Sheets." Geology. $\quad 4: 580-582$.

Sugden, D. E. 1977. "Reconstruction of the Morphology, Dynamics and Thermal Characteristics of the Laurentide Ice Sheet at its Maximum." Arctic and Alpine Research. 9:21-77.

Swanson, D. A., T. L. Wright, and R. T. Helz. 1975. "Linear Vent Systems and Estimated Rates of Magmo Production and Eruption for the Yakima Basalt on the Columbia Plateau." Amer. J. Sci. 275:877-905.

Tierney, M. S. 1977. "Estimating Probabilities of a Disposal System Failure A Status Report." In Proceedings of Workshop Organized Jointly by the OECD Nuclear Energy Agency and the Commission of European Communities, May 23-27. Ispra, Italy. pp. 180-182.

Tubbs, D. W. 1979. "Pacific Northwest Geomorphology and Hydrology-Rates and Probabilities of Selected Processes and Events." In A Summary of FY-1978 Consultant Input for Scenario Methodology Development, ed. B. L. Scott. PNL-2851, Pacific Northwest Laboratory, Richland, Washington.

Veatch, M. D. 1979. "Preliminary Subsurface Hydrologic Considerations. Columbia River Plateau, Physiographic Province, USA." In A Summary of FY-1978 Consultant Input for Scenario Methodology Development, ed. B. L. Scott. PNL-2851, Pacific Northwest Laboratory, Richland, Washington.

Walcott, R. I. 1972. "Post Sea Levels, Eustacy, and Deformation of the Earth." Quaternary Research. 2:1-14.

Weertman, J. H. 1964. "Rate of Growth or Shrinkage of Non-Equilibrium Ice Sheets." Journal of Glaciology. 5:145-158.

Weertman, J. H. 1976. "On Milankovitch Solar Radiation and Variations in Ice Sheet Sizes." Nature. 261:17-20.

Weertman, J. H. 1978. "Creep Laws for the Mantle of the Earth." Philosophical Transactions, Royal Society of London, 288:9-26. 
White, W. A. 1972. "Deep Erosion by Continental Ice Sheets." Bulletin of the Geological Society of America. 83:1037-1056.

Wight, L. H. 1979. "Analys is of the Seismic Hazard to an Underground Waste Repository." In A Summary of FY-1978 Consultant Input for Scenario Methodology Development, ed. B. L. Scott. PNL-2851, Pacific Northwest Laboratory, Richland, Washington.

Winograd, I. J. 1971. "Hydrogeology of Ash Flow Tuff: A Preliminary Statement." Water Resources Research. 7:994-1006.

Winograd, I. J. and W. Thordarson. 1968. "Structural Control of Groundwater Movement in Miogeosynclinal Rocks of South-Central Nevada." In Nevada Test Site, ed. E. B. Eckel. Geol. Soc. America Memoir. 110:35-48.

Zoback, D. A. and T. L. Thompson. 1977. Amendment 23 PSAR 2RC. Washington Public Power Supply System, Richland, Washington. 


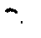

$x$ 
APPENDIX

GLOSSARY OF GEOHYDROLOGIC TERMS 
APPENDIX

\section{GLOSSARY OF GEOHYDROLOGIC TERMS}

Alluvial Fan

Alluvium

Anticline

Aquifer

Aquitard

Basement

Basin
A fan-shaped deposit formed by a stream either where it issues from a narrow mountain valley onto a plain or broad valley, or where a tributary stream joins a main stream.

The detrital materials eroded, transported, and deposited by streams; an important constituent of shelf deposits. Also known as alluvial deposit; alluvion.

A fold in which layered strata are inclined down and away from the axes.

A formation, group of formations, or part of a formation that contains sufficient saturated permeable material to yield significant quantities of water to wells and springs.

A confining bed that retards but does not prevent the flow of water to or from an adjacent aquifer; a leaky confining bed.

1. A complex, usually of igneous and metamorphic rocks, that is overlain unconformably by sedimentary strata. 2. A crustal layer beneath a sedimentary one and above the Mohorovicic discontinuity.

1. A low-lying area, wholly or largely surrounded by higher land, that varies from a small, nearly enclosed valley to an extensive, mountainrimmed depression. 2. An entire area drained by 
Batholith

Block Faulting

Breccia

Cap Rock

Chert

Clastic a given stream and its tributaries. 3. An area in which the rock strata are inclined downward from all sides toward the center. 4. An area in which sediments accumulate.

A body of igneous rock, 40 square miles or more in area, emplaced at great or intermediate depth in the earth's crust.

A type of normal faulting in which the crust is divided into structural or fault blocks of different elevations and orientations. It is the process by which block mountains are formed.

1. Fragmental rock whose components are angular and therefore, as distinguished from conglomerates, are not waterworn. There are friction or fault breccias, talus breccias, and eruptive breccias. 2. A rock made up of highly angular coarse fragments. May be sedimentary or formed by crushing or grinding along faults.

1. A disk-like plate over all or part of the top of most salt domes in the Gulf Coast states composed of anhydrite, gypsum, limestone, and occasionally sulfur. 2. A comparatively impervious stratum immediately overlying an oilor gas-bearing rock.

A hard, dense, micro- or cryptocrystalline rock composed of chalcedony and microcrystalline quartz. Also known as hornstone; phthanite; silexite; white chert.

Rock or sediment composed of fragments that have been transported from their place of origin, as sandstone and shale. 
Conglomerate

Consolidated (material)

Dome

Ephemeral Stream

Epoch

Erosion

Fault

Fault Block

Fault System
Cemented, rounded fragments of water-worn rock or pebbles, bound by a siliceous or argillaceous substance.

In geology, natural materials that have been made firm, cohesive, and hard.

1. A circular or elliptical, almost symmetrical upfold or anticlinal type of structural deformation. 2. A large igneous intrusion whose surface is convex upward.

A stream or reach of a stream that flows briefly only in direct response to precipitation in the immediate locality and whose channel is at all times above the water table. The term may be arbitrarily restricted to a stream that does not flow continuously during periods of as much as one month.

A division of geologic time; when capitalized it becomes a formal division of geologic time corresponding to a series of rock and a subdivision of a period.

The group of processes whereby soil or rock material is loosened or dissolved and removed from a part of the earth's surface.

A fracture or fracture zone along which there has been displacement of the sides relative to one another parallel to the fracture.

A rock mass that is bounded by faults; the faults may be elevated or depressed and not necessarily the same on all sides.

Two or more fault sets that interconnect. 
Fission Product

Fissure

Flood Plain Deposit

Foliation

Geochemistry

Geohydrology

Geoid

Geomor phology

Geophysics

Geothermal

Glacial Lobe
Any radioactive or stable nuclide resulting from nuclear fission, including both primary fission fragments and their radioactive decay products. An extensive crack in a rock.

Sandy and clayey sediment deposited by river water spreading out over a flood plain.

A laminated structure formed by segregation of different minerals into layers that are parallel to the schistosity.

The study of the chemical composition of the various phases of the earth and the physical and chemical processes which have produced the observed distribution of the elements and nuclides in these phases.

The science dealing with underground water, often referred to as hydrogeology.

The figure of the earth considered as a sea-level surface extended continuously over the entire earth's surface.

The study of the origin of secondary topographic features that are carved by erosion in the primary elements and built up of the erosional debris.

The physics of the earth and its environment, that is, earth, air, and (by extension) space. Pertaining to the heat of the interior of the earth.

A tonguelike projection from a continental

glacier's main mass. 
Glacial Maximum

Glaciation

Graben

Ground Water or Groundwater Hydraulic Damming

Hydraulic Gradient

Hydrostatic Pressure

Hydrothermal

Interfluve

Interstice
The time or position of the greatest extent of any glaciation; most frequently applied to the greatest advance toward the equator of Pleistocene glaciation.

Alteration of any part of the earth's surface by passage of a glacier, chiefly by glacial erosion or deposition.

A block of the earth's crust, generally with a length much greater than its width, that has dropped relative to the blocks on either side. Subsurface water occupying a saturation zone. Temporary ponding of water produced by a channel constriction.

Represents the vertical change in the ground-water surface elevations per unit of horizontal.

1. The pressure at a point in a fluid at rest due to the weight of the fluid above it. Also known as gravitational pressure. 2. The negative of the stress normal to a surface in a fluid. An adjective applied to heated or hot aqueous solutions, to the processes in which they are concerned, and to the rocks, ore deposits, and alteration products produced by them. Hydrothermal solutions are of diverse sources, including magmatic, meteoric, and connate waters.

The district between adjacent streams flowing in the same general direction.

An opening or space between one thing and another, as an opening in a rock or soil that is not occupied by solid matter. On the basis of 
Intrusion

Isopach

Joint

Laccolith

Lava

Lithification

Litho logy origin, it may be classified as an original interstice or a secondary interstice; on the basis of size, as a capillary interstice, a subcapillary interstice, or a supercapillary interstice. Syn: void; pore. Adj: interstitial.

1. The process of emplacement of magma in preexisting rock. Also known as injection; invasion; irruption. 2. A large-scale sedimentary injection. Also known as sedimentary intrusion. 3. Any rock mass formed by an intrusive process.

A line drawn on a map through points of equal thickness of a designated stratigraphic unit or group of stratigraphic units. Cf: isochore. Syn: isopachous line; isopachyte; thickness line; thickness contour.

A fracture that traverses a rock and does not show any discernible displacement of one side of the fracture relative to the other.

A body of igneous rock intruding into sedimentary rocks so that the overlying strata have been notably lifted by the force of intrusion.

Fluid rock such as that which issues from a volcano or a fissure in the earth's surface; also the same material solidified by cooling.

1. Conversion of a newly deposited sediment into an indurated rock. Also known as lithifaction. 2. Compositional change of coal to bituminous shale or other rock.

1. The physical character of a rock, generally as determined megascopically or with the aid of a low-power magnifier. 2. The microscopic study and description of rocks. Petrography. 
Loess

Low-Angle Fault

Mafic

Magmatism

Mant le

Monocline

Orogeny

Outcrop

Permeability
An essentially unconsolidated, unstratified calcareous silt; commonly it is homogeneous, permeable, and buff to gray in color, and contains calcareous concretions and fossils. A fault, the dip of which is $45^{\circ}$ or less. Cf: high-angle fault.

Refers to an igneous rock composed chiefly of one or more magnesium and iron-bearing, dark-colored minerals.

The formation of igneous rock from magma.

The intermediate shell zone of the earth below the crust and above the core (to a depth of 3480 kilometers).

A stratigraphic unit that dips from the hor $i-$ zontal in one direction only; not as part of an anticline or syncline.

The process of forming mountains. Especially the intense deformation of rocks by folding and faulting which, in many mountainous regions, has been accompanied by metamorphism, invasion of molten rock, and volcanic eruption; in modern usage, orogeny produces the internal structure of mountains, and epeirogeny produces the mountainous topography. Also known as orogenesis, tectogenes is.

Exposed stratum or body of ore at the surface of the earth. Also known as cropout.

The capacity of a porous rock, soil, or sediment for transmitting a fluid without damage to the structure of the medium. Also known as perviousness. 
Plateau Basalt

Pluton

Pluvial

Porosity

Recharge

Regional Metamorphism

Rift
A term applied to those basaltic lavas that occur as vast composite accumulations of horizontal or subhorizontal flows and which, erupted in rapid succession over great areas, have at times flooded sectors of the earth's surface on a regional scale. They are generally believed to be the product of fissure eruptions.

In the strictest sense, a body of igneous rock that has formed beneath the surface of the earth by consolidation from magma. In a broader sense, it may include bodies composed of pseudoigneous rock that formed beneath the surface of the earth by the metasomatic replacement of an older rock. 1. Due to the action of rain. 2. Pertaining to deposits by rainwater or ephemeral streams.

That portion of an aquifer's volume which consists of openings or pores; that is, the proportion of its volume not occupied by solid material. Porosity is an index of how much ground water can be stored in the saturated material and is usually expressed as a percentage of the bulk volume of the material.

1. The processes involved in the replenishment of water to the zone of saturation. 2. The amount of water added or absorbed. Also known as ground-water increment; ground-water recharge; ground-water replenishment; increment; intake. Geological metamorphism affecting an extensive area.

1. narrow opening in a rock caused by cracking or splitting. 2. A high, narrow passage in a cave. 
Rift Valley

Rift Zone

Roentgen ( $R$ )

Runoff

Sed imentary Basin

Seismicity

Shield

sill

Sinkhole
A deep, central cleft with a mountainous floor in the crest of a midoceanic ridge. Also known as central valley; midocean rift.

A system of crustal fractures and faults. Unit of air exposure to electromagnetic radiation (IR $=2.58 \times 10^{-4}$ coulombs $/ \mathrm{kg}$ air $)$.

1. Surface streams that appear after precipitation. 2. The flow of water in a stream, usually expressed in cubic feet per second; the net effect of storms, accumulation, transpiration, meltage, seepage, evaporation, and percolation. Geologically depressed area with thick sediments in the interior and thinner sediments at the edges.

The phenomena of earth movements. Also known as seismic activity.

A continental block of the earth's crust that has been relatively stable over a long period of time and has undergone only gentle warping in contrast to the strong folding of bordering geosyclinical belts. Mostly composed of precambrian rocks.

1. Submarine ridge in relatively shallow water that separates a partly closed basin from another basin or from an adjacent sea. 2. A tabular igneous intrusion that is oriented parallel to the planar structure of surrounding rock.

A funnel-shaped depression in the land surface generally in a limestone region communicating with a subterranean passage developed by solution. 
Slickenside

Static Head

Stock

Strain

Stratigraphy

Stratum

Strike-Slip Fault
A surface that is polished and smoothly striated and results from slippage along a fault plane. Pressure of a fluid due to the head of fluid above some reference point.

(Geol) See pipe. (Petr) A usually discordant, batholithlike body of intrusive igneous rock not exceeding 40 square miles in surface exposure and usually discordant.

Change in length of an object in some direction per unit undistorted length in some direction, not necessarily the same; the nine possible strains form a second-rank tensor.

A branch of geology concerned with the form, arrangement, geographic distribution, chronologic succession, classification, correlation, and mutual relationships of rock strata, especially sedimentary. Also known as stratigraphic geology. A tabular or sheet-like mass, or a single and distinct layer, or homogeneous or gradational sedimentary material (consolidated rock or unconsolidated earth) of any thickness visually separable from other layers above and below by a discrete change in the character of the material deposited or by a sharp physical break in deposition, or by both; a sedimentary bed. The term should be restricted to sedimentary material and is generally considered to be synonymous with "bed". The term frequently used in its plural form, strata. Lamina.

A fault, the actual movement of which is parallel to the strike of the fault. 
Syncline

Tectonic

Tecton ism

Terrace

Thrust Fault

Topography

Transmissivity
A fold in rocks in which the strata dip inward from both sides toward the axis. Ant: anticline. of, pertaining to, or designating the rock structure and external forms resulting from the deformation of the earth's crust. As applied to earthquakes, it is used to describe shocks not due to volcanic action or to collapse of caverns or 1 andslides.

1. Crustal instability. 2. The structural behavior of an element of the earth's crust during, or between, major cycles of sedimentation. 1. A horizontal or gently sloping embankment of earth along the contours of a slope to reduce erosion, control runoff, or conserve moisture. 2. A narrow coastal strip sloping gently toward the water. 3. A long, narrow, nearly level surface bounded by a steeper descending slope on one side and by a steeper ascending slope on the other side. 4. A benchlike structure bordering an undersea feature.

A low-angle (less than a $45^{\circ}$ dip) fault along which the hanging wall has moved up relative to the footwall. Also known as reverse fault; reverse slip fault; thrust slip fault. The physical features of a district or region, such as are represented on maps, taken collectively; especially, the relief and contour of the land.

In an aquifer, the rate at which water of the prevailing kinematic viscosity is transmitted through a unit width under a unit hydraulic 
gradient. Though spoken of as a property of the aquifer, it embodies also the saturated thickness and the properties of the contained liquid.

Underthrust A thrust fault in which the lower, active rock mass has been moved under the upper, passive rock mass.

Uplift

Elevation of any extensive part of the earth's surface relative to some other parts.

Upwarping The upwards warping or uplift of a regional area of the earth's crust, usually as the result of the release of isostatic pressure, e.g., melting of an ice sheet.

Water Table

The planar surface between the zone of saturation and the zone of aeration. Also known as freewater elevation, free-water surface, ground-water level, ground-water surface, ground-water table, level of saturation, phreatic surface, plane of saturation, saturated surface, water level, waterline. 


\section{DISTRIBUTION}

No. of

Copies

OFFSITE

A. A. Churm

DOE Chicago Patent Group 9800 South Cass Avenue

Argonne, IL 60439

27 DOE Technical Information Center

2 Argonne National Laboratory

Reference Library

9800 South Cass Avenue

Argonne, IL 60439

20 Battelle Memorial Institute

Office of Nuclear Waste Isolation

Attn: Beverly Rawles

$505 \mathrm{King}$ Avenue

Columbus, $\mathrm{OH} 43201$

Myr 1 Beck

Department of Geology

Western Washington University

Bellingham, WA 98225

John Bird

Geology Department

Corne 11 University

Ithaca, NY 14853

Pat Brannen

Sandia Laboratory

P.0. Box 5800

Albuquerque, NM 87115

John Bredehoeft

U.S. Geological Survey

Reston, VA 22092
No. of

Copies

2 Brookhaven National Laboratory

Reference Section

Information Division

Upton, Long Is I and, NY 11973

Robert Budnitz

U.S. Nuclear Regulatory

Commission

Washington DC 29545

Colin Bull

Office of the Dean

College of Math and Physical

Sciences

Ohio State University

164 W. 17th Avenue

Columbus, $\mathrm{OH} 43201$

Harry C. Burkholder

Office of Nuclear Waste

Isolation

Battelle Memorial Institute

505 King Avenue

Columbus, $\mathrm{OH} 43201$

Jim Campbel1

T39

Division 5413

Sandia Laboratories

Albuquerque, NM 87185

Wayne A. Carbiener

Office of Nuclear Waste Isolation

Battelle Memorial Institute

505 King Avenue

Columbus, $\mathrm{OH} 43201$

H. Clyde Claiborne

Oak Ridge National Laboratory

P.0. Box X, Building 3017

Oak Ridge, TN 37830 
No. of

Copies

James Clark

4732, Geotechnology Division

Sand ia Laboratories

Albuquerque, NM 87185

James Clark

c/o Eugene Vetter

Route 2, Box70

Shawano, WI 54166

Neville G. W. Cook

Dept of Materials Science and Mineral Engineering

Hearst Mining Building

University of California

Berkeley, CA 94720

Carl R. Cooley

DOE Office of Nuclear Waste Management

Washington, DC 20545

Howard A. Coombs

Department of Geological Sciences

University of Washington

Seattle, WA 98194

James W. Cros by III

1467 Alpowa

Moscow, ID 83843

Bruce Crowe

Geological Research Group, G-6

Los Alamos Scient if ic

Laboratory

P.0. Box 1663

LoS Alamos, NM 87545

Jared Davis

27 Nuclear Regulatory Commission

Washington DC 20555

Stan ley Dav is

810 N. Camino Santiago \#20

Tucson, AZ 85705
No. of

Copies

G. L. DeBuchannanne

U.S. Geological Survey

Reston, VA 22092

Terry Donich

Lawrence Livermore Laboratory

P.0. Box 808

Livermore, CA 94550

James Duguid

Office of Nuclear Waste

Isolation

Battelle Memorial Institute

Columbus, $\mathrm{OH} 43201$

Thomas Dunne

5511 16th NE

Seattle, WA 98105

Don Easterbrook

Western Washington University

Bellinham, WA 98225

Dan Egan

U.S. Environmental Protection Agency

Washington DC 20545

Environmental Protection Agency

Office of Radiation Programs

Technology Assessment Division

M/S AW559

Washington, DC 20460

J. G. Feinste in

NUS Corporation

4 Research Place

Rockville, MD 20850

Graham E. Fogg

Bureau of Economic Geology

The University of Texas at Aust in

University Station, Box $X$

Aust in, TX 78712 
No. of

Copies

Robert M. Garre 1ls

Dept. of Geologic Sciences

Northwestern University

Evanston, IL 60201

Raymond D. Gastil

Freedom House

$20 \mathrm{~W}$. 40th St.

New York, NY 10018

Earnest Gloyna

National Academy of Sciences

University of Texas

Aust in, TX 78712

George Griswold

Tecolote Corporation

531 Wagon Train Drive SE

Albuquerque, NM 87123

Char les R. Had lock

Arthur D. Little, Inc.

Acorn Park

Cambridge, MA 02140

William Hartmann

2224 E. Fourth Street

Tucson, AZ 85719

Colin A. Heath

DOE Division of Waste

Management

Washington DC 20545

William M. Hewitt

Office of Nuclear Waste

Isolation

Battelle Memorial Institute

505 King Ave.

Columbus, $\mathrm{OH} 43201$

John M. Hills

818 Kerbey Ave.

El Paso, TX 79902
No. of

Copies

Peter L. Hofmann

Office of Nuclear Waste Isolation

Battelle Memorial Institute 505 King Avenue

Columbus, $\mathrm{OH} 43201$

John T. Holloway

Committee on Radioactive Waste

Management $\mathrm{JH}-826$

National Academy of Sciences

2101 Constitution Ave. NW

Washington DC 20418

Vojin Joksimovic

General Atomic Company

P.0. Box 81608

San Diego, CA 92138

Lou is S. Karably

Law Engineering

2749 Delk Road SE

Marietta, GA 30067

R. F. Kaufman

Evaluation Branch

Office of Radiation Programs

U.S. Environmental Protection Agency

P.0. Box 18416

Las Vegas, NV 89114

Ralph Kehle

7800 Shoul Creek Blvd.

Suite 2705

Austin, TX 78757

Muzaffer Kehnemuyi

Office of Nuclear Waste

Isolation

Battelle Memorial Institute

505 King Ave.

Columbus, $\mathrm{OH} 43201$ 
No. of

Copies

John F. Kircher

Office of Nuclear Waste

Iso lation

Battelle Memorial Institute

505 King Ave.

Columbus, $\mathrm{OH} 43201$

Char les Koplick

The Analytic Sciences Corp.

6 Jacob Way

Reading, MA 01867

Charles W. Kreitler

Texas Bureau of Economic Geo logy

University Station, Box $X$

Austin, TX 78712

George K. Kuk la

Lamont-Doherty Geological

Observatory

Palisades, NY 10964

Donald H. Kupfer

Department of Geology

Lou is ianna State University

Baton Rouge, LA 70803

James G. LaBastie

Law Engineering and Testing Co.

2749 Delk Road SE

Marietta, GA 30067

Rona ld B. Lantz

INTERA Environmental

Consultants, Inc.

11511 Katy Freeway

Houston, TX 77079

2 Lawrence Berkeley Laboratory

Reference Library

University of California

Berkeley, CA 94720

2 Lawrence Livermore Laboratory

Reference Library

P.0. Box 808

Livermore, CA 94550
No. of

Copies

\author{
Darre 11e I. Leap \\ USGS, WRD, MS416 \\ Box 25046 \\ Denver Federal Center \\ Denver, CO 80225 \\ Richard Lincoln \\ Sandia Laboratories \\ N.N.W.S.I. \\ NTS Technical Overview \\ Division 4538 \\ Albuquerque, NM 87185
}

Stan ley E. Logan

Nuc lear Waste Management

Program

Los Alamos Technical

Associates, Inc.

P.0. Box 410

Los Alamos, NM 87554

2 Los Alamos Scientific Laboratory

Reference Library

P.0. Box 1663

Los Alamos, NM 87544

Ear 1 M. Lovejoy

4400 Fairview Road

Reno, NV 89511

S. J. Mara

SRI International

333 Ravenswood Avenue

Men lo Park, CA 94025

J. B. Martin

Ass istant Director for

Radioactive Waste Management

Branch

NRC Division of Materials and

Fuel Cycle Facility Licensing

Washington DC 20555

Peter D. Mattison

Arthur D. Little, Inc.

Acorn Park

Cambridge, MA 02140 
No. of

Copies

W. C. McClain

Oak Ridge National Laboratory

P.0. Box $X$

Oak Ridge, TN 37830

John T. McGinn is

Office of Nuclear Waste Isolation

Battelle Memorial Institute

505 King Ave.

Columbus, $\mathrm{OH} 43201$

She Idon Meyers

DOE Office of Nuclear Waste Management

Washington DC 20545

Peter A. Mote

Bechte 1, Inc.

P.0. Box 3965

San Francisco, CA 94105

2 Barry Naft

NUS Corporation

4 Research Place

Rockville, MD 20805

J. 0. Neff

Department of Energy

Columbus Program Office

505 King Ave.

Columbus, $\mathrm{OH} 43201$

Robert H. Neil

State of New Mexico

Environmental Evaluation Group

P.0. Box 968

Santa Fe, NM 87503

Ivars Neretnieks

Earth Science Division

Lawrence Berkeley Laboratory

University of California

Berkeley, CA 94720
No. of

Copies

2 Neit Norman

Environmental Sciences Dept.

Bechtel National, Inc.

P.0. Box 3965

San Francisco, CA 94105

2 Oak Ridge National Laboratory

Central Research Library

Document Reference Section

Oak Ridge, TN 37830

Suresh B. Pahwar.

INTERA Environmental

Consultants, Inc.

11511 Katy Freeway, Suite 630

Houston, TX 77079

Frank L. Parker

Dept. of Environmental

Engineering

Vanderbilt University

Nashville, TN 37235

James Pearson

INTERA Environmental Consultants, Inc.

11511 Katy Freeway, Suite 630

Houston, TX 77079

George F. Pinder

Dept. of Civil Engineering

Princeton University

Princeton, NJ 08540

Larry Ramspott

Technical Program Officer

Lawrence Livermore Laboratory

P.0. Box 808

Livermore, CA 94550

Linda Robinson

NUS Corporation

4 Research Place

Rockville, MD 20850 
No. of

Copies

Savannah River Laboratory

Reference Library

Aiken, SC 29801

Maurice L. Schwartz

Department of Geology

Western Washington University

Bellingham, WA 98225

Genevieve Segol

Bechte 1, Inc.

P.0. Box 3965

San Francisco, CA 94105

Herb Shaw

U.S. Geological Survey

Mail Stop 18

345 Middlefield Road

Men lo Park, CA 94025

Dillard B. Shipler

Office of Nuclear Waste Isolation

Battelle Memorial Institute

505 King Ave.

Columbus, $\mathrm{OH} \quad 43201$

James N. Siltanen

General Atomic Company

P.0. Box 81608

San Diego, CA 92138

George M. Slaughter

Law Engineering and Testing Co.

2749 Delk Road SE

Marietta, GA 30067

Barry J. Smernoff

Hudson Institute

Quaker Ridge Road

Croton-On-Hudson, NY 10520

Pierre St. Amand

Earth and Planetary Sciences

Naval Weapons Center

China Lake, AC 93555
No. of

Copies

Terry Ste inborn

Lawrence Livermore Laboratories

P.0. Box 808

Livermore, CA 94550

Howard P. Stephens

Sandia Laboratories

N.N.W.S.I.

Division 4538

Albuquerque, NM 87185

James I. Stevens

Arthur D. Little, Inc.

Acorn Park

Cambridge, MA 02140

David B. Stewart

U.S. Geological Survey

National Center 959

Reston, VA 22092

Robert L. Thoms

Institute for Environmental

Studies

Louisiana State University

Baton Rouge, LA 70803

Newe 11 Trask

U.S. Department of the Interior Geological Survey

Mail Stop 929

Reston, VA 22092

W. S. Twinhofel

USGS

Mail Stop 954

Denver, CO 80225

Maurice D. Veatch

6834 - 51st Ave. NE

Seattle, WA 98115

W. Weart

Division 1140

Sandia Laboratories

Albuquerque, NM 87115 
No. of

Copies

Lawrence Wight

TERA

2150 Shaltuck Ave.

Berkeley, CA 94704

Robert Williams

Electric Power Research

Institute

3412 Hillview Avenue

P.0. Box 10412

Palo Alto, CA 94304

Charlie Wilson

Earth Sciences Division

Lawrence Livermore Laboratory

Building 90

Berkeley, CA 94720

Paul Witherspoon

Earth Sciences Division

Lawrence Livermore Laboratory

Building 90

Berkeley, CA 94720

FOREIGN

D'All ess andro Avogadro

Commssion of European Commun ities

Joint Research Centre

I-21020 Ispra (Varese)

ITALY

V. K. Barwe 11

Environmental Research Branch

Atomic Energy of Canada Limited

Chalk River, Ontario KOJIJ0

CANADA

Le if Carlsson

Geological Survey of Sweden

Bredgrand 4

S-753 20 UPPSALA

$018 / 1556 \quad 40$

SWEDEN
No. of

Copies

Center for Atomic Energy Documentation (ZAED)

Attn: Dr. Bell

Postfach 3640

D-7500 Karlsruhe

F.R. OF GERMANY

Ken Dornuth

Atomic Energy Canada Limited

Whiteshe 11 Nuclear Research Establishment

Pinawa, Manitoba ROE 1 LO

CANADA

F. Gera

Nuclear Energy Agency/OECD

38 boulevard Suchet

75016 Paris

FRANCE

K. H. Hubentha1

Bundesministerium fur Forschung und Technologie

Stressemannstrasse 2

Postfach 200706

D-5300 Bonn

F.R. OF GERMANY

2 INIS Clearinghouse

International Atomic Energy Agency

P.0. Box 590

A-1011, Vienna

AUSTRIA

Klaus Kuhn

Institut fur Tiefagerung

Wis senschaft 1 iche Abteilung

Berliner Strasse 2

D-3392 Clausthal - Zellerfeld

F.R. OF GERMANY

Hans W. Levi

Hahn-Meitner-Institut fur Kernforschung

Glienicker Strasse 100

D-1000 Berlin 39

F.R. OF GERMANY 
No. of

Copies

Library

Studsvik Energiteknik $A B$

S-611 01 Nykoping

SWEDEN

Glenn Merrett

Atomic Energy Canada Limited

Whiteshe 11 Nuclear Research

Establi shment

Pinawa, Manitoba ROE $1 L 0$

CANADA

Takehico Ngamatsu, Geologist Chief Representative Vancouver Office

Mitsubishi Metal Corporation

78 Granville Square

200 Granville Street

Vancouver, BC V6C 1S4

CANADA

Franz Peter Oester le

Physikalisch-Chemische Bundes anstalt

Bundesallee 100

D-3300 Braunschweig

F.R. OF GERMANY

Ton is Papp

Karnbrans lesakerhet

Fack. 10240

Stockholm

SWEDEN



F. P. Sargent

Atomic Energy of Canada Limited Whiteshell Nuclear Research Establishment

Pinawa, Manitoba ROE 1LO CANADA
Noritaka Sato
Chief Geologist, Domestic
Exploration \& Nuclear
Resources
Mitsubishi Metal Corporation
1-5-2 Ohte-Mach $i$
Chiyoda-Ku, Tokyo
JAPAN

No. of

Copies

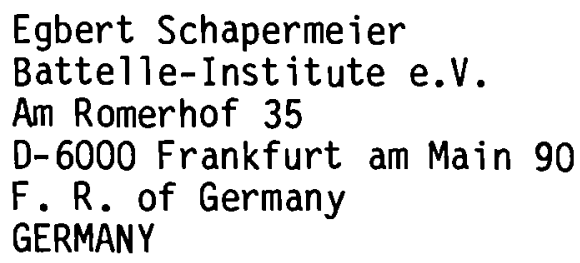

Egbert Schapermeier

Battelle-Inst itute e.v.

Am Romerhof 35

D-6000 Frankfurt am Main 90

$F$. R. of Germany

GERMANY

Tjalle Vandergraff

Atomic Energy of Canada Limited

Whiteshell Nuclear Research Establishment

Pinawa, Manitoba ROE 1LO

CANADA

\section{ONSITE}

5 Department of Energy

0. J. Elgert

H. E. Ransom

J. J. Schreiber

D. J. Squires

F. R. Standerfer

7 Rockwell Hanford Operations

R. L. Biggerstaff

D. J. Brown

R. A. Deju

G. S. Hunt

R. E. Isaacson

G. L. Jones

Rockwel1 Document Control

72

Pacific Northwest Laboratory

E. M. Arnold

D. J. Bradley

A. Brandstetter (10)

J. B. Brown

D. B. Cear lock

V. L. Coburn

R. A. Craig

W. J. Deutsch

F. H. Dove

D. W. Dragnich

J. R. Eliason

E. A. Eschbach

H. P. Foote 
No. of

Copies

J. Greenborg

R. J. Hall

M. A. Harwell

A. J. Haverfield

B. W. Howes

J. H. Jarrett

M. R. Kreiter

I. S. Levy

J. S. Light

J. W. Lindberg

R. P. Marshall

L. M. Martucci

R. F. McCallum

J. L. McElroy

J. MCGinn is

K. S. Murthy

R. W. Nelson

R. E. Nightingale

H. M. Parker
No. of

Copies

G. M. Petrie

A. M. Platt

J. R. Raymond

J. F. Relyea

B. L. Scott

R. J. Serne

D. J. Silviera

J. G. Stephan

J. A. Stottlemyre

R. P. Turcotte

R. W. Wallace

R. A. Walter

W. R. Wiley

J. T. Zellmer

Technical Information Library (5)

Publishing Coordination $\mathrm{SH} / \mathrm{B}(2)$

Water and Land Resources

Department Library (10) 
2
1 